Historic, Archive Document

Do not assume content reflects current scientific knowledge, policies, or practices. 

62.31

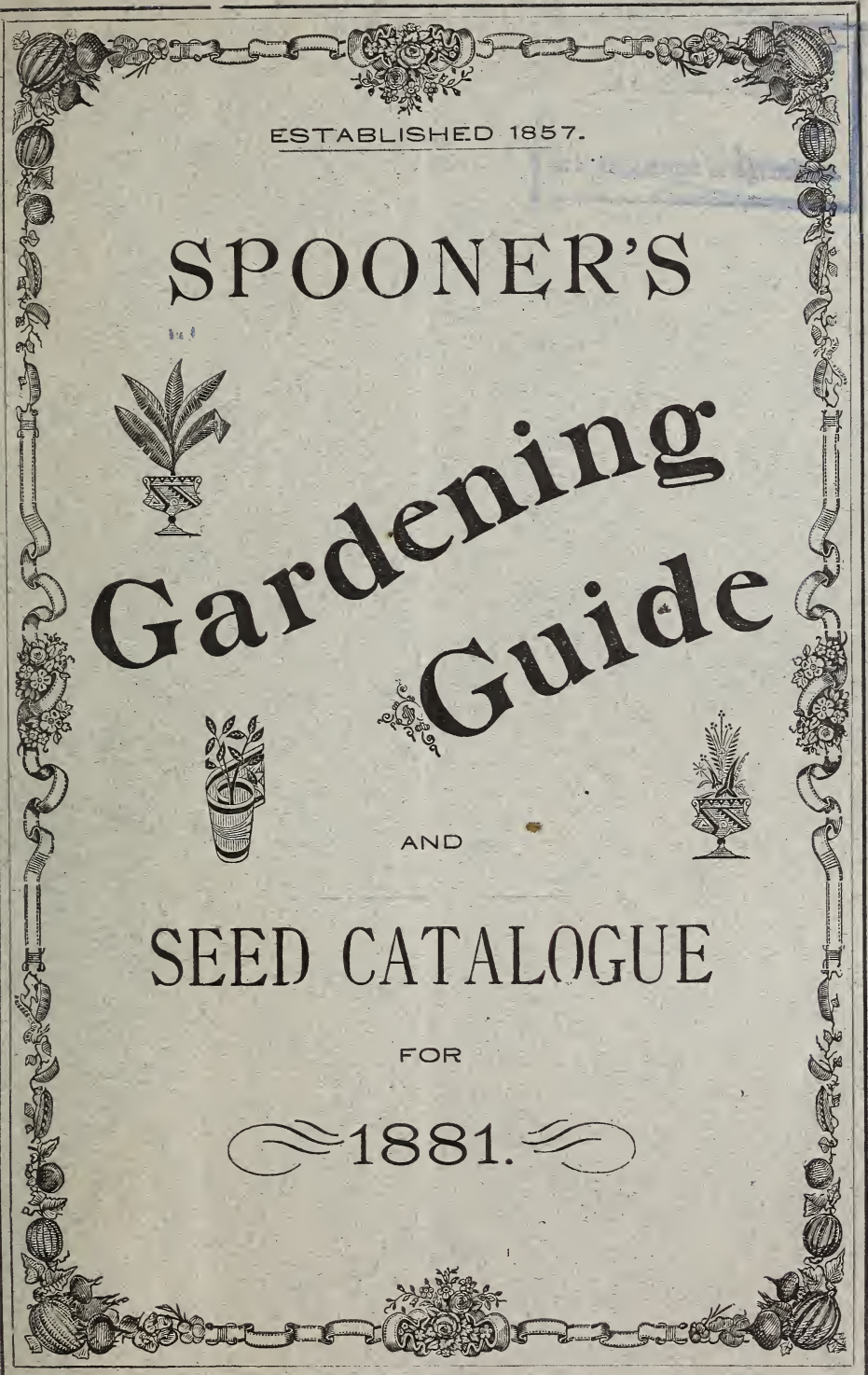

CUNN, BLISS \& CO, PRINTERS, BUSTON, 


\section{Spooner's Choice Flower Seeds.}

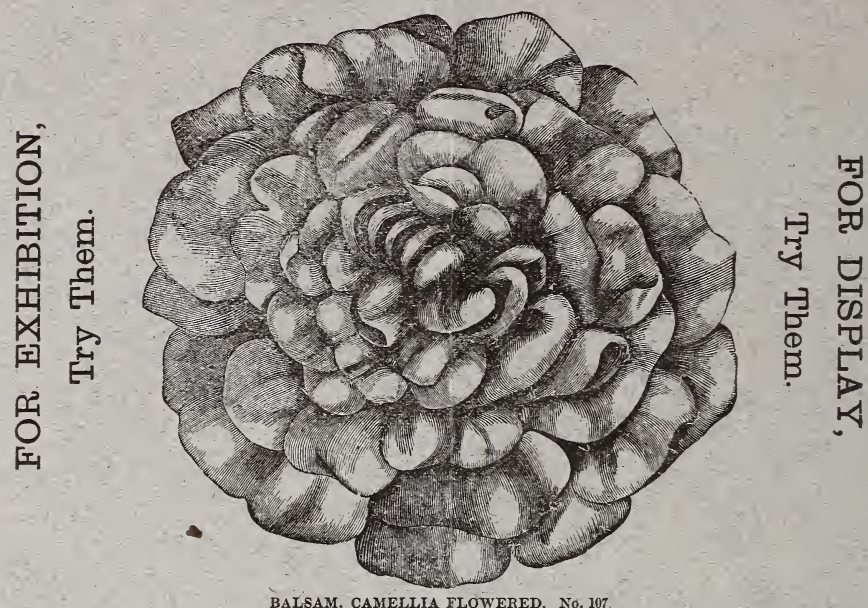

Everv farmer or cultivator of land, on however smill a scale, should take one or more of the best and most progressive A gricultural and Horticultural Papers or Magazines. A selcetion from any of the' lollowing will_be found desirable:

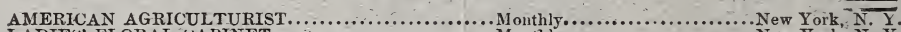

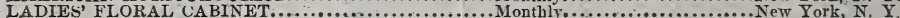

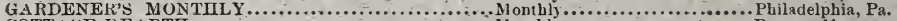

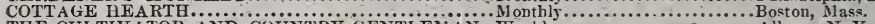

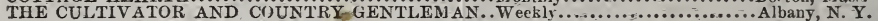

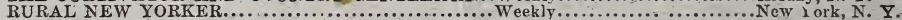

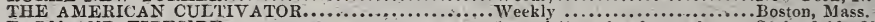

FARD AND FIRESIDE..............................

\section{SOME EXPERIENCE IN HARDY ROSE CULTURE; Or, Rose Growing Simplified.}

AN ESSAY BY

\section{WILLIAM H. SPOONER,}

Chairman Plant and Flower Committee, Massachusetts Horticultural Society.

Read before the Massachusetts Horticultural Society, Boston, Mass., January 8th, 1881, The Worcester County Horticultural Society, Worcester, January 27th, 1881,

With sume additional notes.

The above Essay mailed free to every purchaser of $\$ 1$ worth of seeds.

A List of Hybrid Perpetual Roses, budded upon the Manetti Stock, fine imported Plants, will be mailed free to applicants about April 1.

Some varieties of vegetable seeds are quoted at higher rates this season, such as Wrinkled Peas, Cabbage, Celery, Onion and Turnip seed, the long.continued drought of the past season seriously lessening the seed harvest. 


\section{SPOONFR'S}

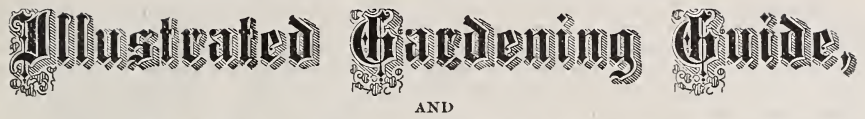

\section{STED CAIATOGUI.}

\section{A WORD TO PURCHASERS.}

All my seeds are carefully tested before sending out, to prove their germinating qualities; they are grown on my own grounds, or by skilled French, German or American cultivators.

Seeds and Bulbs Free of Postage.-The present postal law authorizes the sending of seeds and bulbs to all parts of the United States at the rate of one cent per ounce. It matters not how many varieties are sent, provided the weight does not exceed four pounds; if larger lots are wanted, they can be divided into four pound parcels ; this arrangement enables persons in distant parts of the country to obtain seeds and bulbs as cheaply as our nearest neighbors, as I pay the postage here and guarantee the safe arrival of the goods at their destination. The exceptions to this rule are when Grass Seed, or heavy goods are ordered by the pound, quart, peck or bushel, or in articles at special quotations.

By Express. - We can frequently send mailable parcels as cheap by express as by mail, and prefer to do so when just as convenient to purchasers, in which case we pay express charges. Customers will please name their nearest express office, and if convenient to receive goods in this way; but we desire to have it clearly understood that we do not agree to pay transportation charges on heary articles quoted by the pound, quart, peck, etc., unless the cost of the same, 16c. per pound, or 20c. per quart extra, is remitted with the order.

To Prevent Mistakes.-Please write full Name, Town, Country and State, plainly. We frequently receive orders with neither name nor address, and all such have to wait the sender's complaint that his or her seeds have not come to hand.

The Safe Arrival of Goods Guaranteed.-I guarantee the safe arrival of packages in good condition to my customers; if not received by them in seasonable time, I will, upon being notified, and receiving a duplicate of order, with date, refill the same without additional expense to customers; as my desire is to deal honestly with all who may favor me with their patronage, without giving them any more expense or risk than if purchasing from a neighbor.

How to 0rder.-In ordering flower seeds or gladiolus, it is only necessary to write the number, which is a great saving of time and labor to both the purchaser and ourselves. In ordering vegetable seed, it will be necessary to mention the variety. Please be particular to WRITE THE QUANTITY PLAINLY.

\section{HOW TO SEND MONEY.}

With the following precautions in sending money it can be sent at MY RISK and EXPENSE, by Post OFFICE MONEY ORDER, costing from 5c. to $25 \mathrm{c}$., and perfectly safe. All offices are not authorized to issue them. Drafts on New York or Boston, costing about 25c. Most banks issue them. REGISTERED LETTERs.-All postmasters are obliged to register when requested to do so. Enclose the money in your letter in his presence, and take his receipt; it costs $10 \mathrm{c}$. When remittances are made in conformity with above directions they can be sent at my expense by deducting cost from amount sent, for orders of $\$ 1.00$ and uproards.

My Guarantees.-With the terms which I propose to purchasers, it will be seen there is absolutely no risk in sending to me for seeds. 1st, I warrant that all money sent as previously directed shall reach me safely. 2nd, That all goods bought of me shall reach the purchaser in good order and condition. 3rd, If any seeds purchased of me are not as represented, I will replace them with other seed, either this season or next, free of charge.

Or, in other words, I guarantee everything but the crop, that Iclearly cannot do, there are so many causes to affect the latter from peculiarities of season, soil, or mode of culture, that are entirely beyond my control. Ondens Promptiy Executed. Address,

P. O. Box 3125 .

WILLIAII H. SP00NER, Boston, Mass. Hurse Cars trom Tremont House.

Office and Gardens-Centre, near Boylston St., Jamaica Plain District. 


\section{HINTS ON THE SOWING OF SEEDS.}

Annuals, though largely grown on account of the convenience of having them so quickly in bloom after sowing, have come into some disfavor through their supposed fugacious habit. It is easy to show, however, that much of the ephemeral quality is due to errors on the part of cultivators rather than to the nature of the plants. To cultivate Annuals properly they should have the same care as Geraniums, Verbenas, or such like, especially in the fact of giving them room to grow in. The too common practice of sowing Annuals as thickly as mustard and cress, and leaving them thus huddled together in a dense mass, produces, it is true, a rapid effect ir the speedy production of flowers; but the plants are soon exhausted and wither away. The remedy is obvious: they must be "thinned out," or planted out at a fair distance from one another, and with room to produce both root and leafnge. The blooms will come in due time, upon handsome and well-furnished plants, and continue to encourage the cultivator, more or les", throughout the whole summer.

Hardy Annuals may be sown out of doors as soon as open weather has fairly set in, about May, or beginning of June. From this time outwards to the end of early summer rains, sowings may be made. Sow thinly on finely raked soil; as the plants rise, thin them out carefully, until they stand ultimately at a sufficient distance from each other to allow of the growth peculiar to the species. Tall or spreading kinds will require to be eight to twelve inches apart; smaller kinds of course, less-say three to eight inches.

Half-Hardy Annuals are those which, being of a tenderer nature than the above, will not germinate in soll at so low a temperature. They, therefore, need to be raised under glass, or some protection, or their sowing deferred until the out-door temperature is suffciently high. This is usually the case from the end of May to middle of June.

Biennials and Perennials for out-door culture, are best sown in the open ground in June or July; rainy, moist weather should be chosen, and their management will then be of the easiest and simplest kind. When large enough to handle, plant the seedlings out, either at once into the quarters where the plants are to remain, or into some spot out of the way, to be ultimately transferred as required into the position they are to occupy, if possible, not later than September or October. Many of these if sown early under glass and transplanted will bloom the first season from seeds.

Greenhouse or Stove Plants raised from seed are treated in the way above described, but in the hot-bed for the first stage. The greater the amount of heat, with proportionate moisture, the better for stove kinds; when up and large enough, they are potted off, either at once singly, or severul together, with another shift later. Ultimately, they occupy positions singly in pots, in the stove or greenhouse as the case may be.

Sowing should never be done upon soil in a very wet condition. As a general rule, the surface should be rather dry than wet. Seeds should never be sown too deep; this is a fertile cause of failure with the inexperienced. A depth of about twice the average diameter of the seeds themselves is a good general principle to follow in this respect. This will bring the majority of seeds but just under the surface, and some of the very finest will not be actually covered at all, but just sprinkled over the surface and a little pressure applied. This is quite sufficient. As a rule, the more thinly the seeds are strewn the better. If seeds are sown in dry weather, water must be given from a fine rose water pot, and unless rain comes, must be followed up regularly every day or two, as it is certain to be fatal to seeds just sprouted if absolute drought should overtake them. It is obvions that moist and rainy weather is the best for seed sowing. If the water-pot is used, it must be done with judgment. An excess of moisture is as harmful as too little, and will produce decay. The seedsman repeatedly gets blame for the non-growth of seeds when the failure is entirely attributable to neglect of the above precautions.

An English cultivator suggests the following theory for germinations: "Sow your seeds in the usual way, only cover up and keep in total darkness until they begin to peep above the soil, then gently and gradually expose them to the light; the success of all good seed will follow, and become a lasting practice and benefit."

\section{SPECIAL PREMIUMS TO FORMER PATRONS.}

Any of my former patrons sending me the name of a new enstomer, with order to the amount of $\$ 1.00$, or upwards, enclosing the sum as before directed, can select in addition to such order, seeds in packets to the amount of one-half the order so sent. I make this liberal offer feeling sure my old customers will be glad to help me extend my business in their neighborhoods.

Evidence of Quality.

I have never had as good a garden as the year I bought I have never had as good \& garden as the year
I was glad to see; enclosed please find an order.
WashoE Citx, March 1, 1879. seeds of you. I received your new Guide which Yours respectfuliy,

L. S. G. 


\section{THE FORMATION OF CLUBS.}

Desirous of extending the cultivation of my flower and vegetable seeds as extensively as possible through the country, and knowing there may be persons in a neighborhood who will not take the trouble, perhaps, to get my Catalogue, and send for seeds, I offer the following inducements to those who wish to purchase largely, or for the formation of clubs, by which a great saving can be made. The seeds will be forwarded, BY MAIL, POSTPAID to one address, or in separate packages, and mailed to the address of each individual forming the club, on receipt of the price.

Persons sending $\$ 1.00$ may select seeds in packets, amounting to $\$ 1.25$

\begin{tabular}{|c|c|c|c|c|c|c|c|}
\hline “6 & " & 2.00 & " & " & " & " & 2.60 \\
\hline " & " & 3.00 & " & “ & " & " & 3.90 \\
\hline “ & " & 4.00 & “ & " & " & " & 5.50 \\
\hline “ & “ & 5.00 & “" & “ & " & “ & 7.0 \\
\hline “ & ". & 10.00 & "6 & " & " & " & 14.5 \\
\hline " & “" & 20.00 & "، & . & ، & “ & 30.0 \\
\hline
\end{tabular}

The above premiums apply only to Flower and Vegetable Seeds, in RETAIL PACKETs. and I desire it to be distinctly understood that Seeds quoted by the ounce and pound are not included, neither are Bulbs and Plants.

I have the following collections put up to accommodate persons not familiar with the different varieties, on which a very large discount has been made:

Collection A contains thirty varieties of choice Annual Flower Seeds, $\quad$ per mail, $\$ .90$

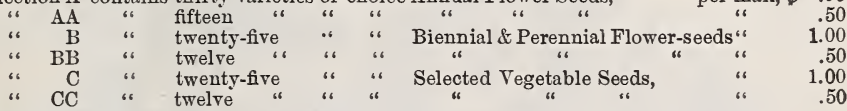

The above collections will be included in club rates.

\section{FLOWER SEEDS IN COLLECTIONS.}

The following are imported seeds, and include only the best known varieties, carefully saved from the purest stocks and finest quality, extra double flowers. THEY ARE IMPORTED IN Seaned Packets, and are unsurpassable.

825 .

826.

ASTERS.-Truffaut's Paeony-flowered perfection, eighteen splendid varieties

$\$ 1.00$

834. " " Dwarf Chrysanthemum, eight varieties, large flowered..........

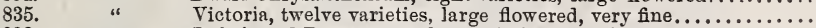

828. " Imbricated Pompon, twelve varieties, very fine for bouquets....

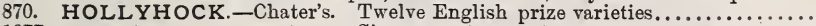

1077. " " Six " " "

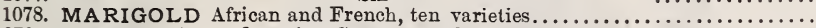

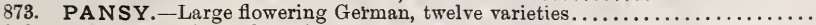

849. STOCKS.-Large flowering German, Ten Week, robust habit of growth, free

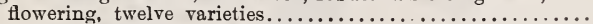

854. " a Branching German, Ten Week, fine, one of the best for bouquets,

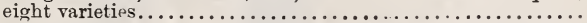

883. TROP EOLUM LOBBIANUM, tall, twelve choice Farieties, with brilliant

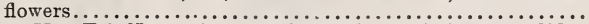

883a. MAJUS (Tall Nasturtium), twelve choice varieties, splendid..

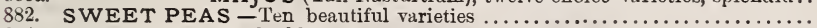

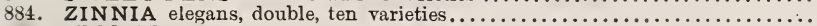

1081. SPECIAL. - I will forward one ounce of my celebrated Nasturtiums and Tropæolums, tall varieties, the two classes mixed, for 35 cents.

\section{Evidence of Quality :} ones.

Delhi, New York, March 30, 1879.

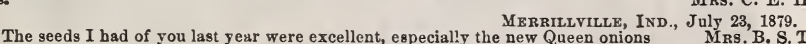

We received the last package of seeds all right. We are well pleased with all the seeds you have sent us and they have proved to be just what we ordered. Yours, F. S. WORTHEN \& SON, Manchester, N. H. ection for the mixed 


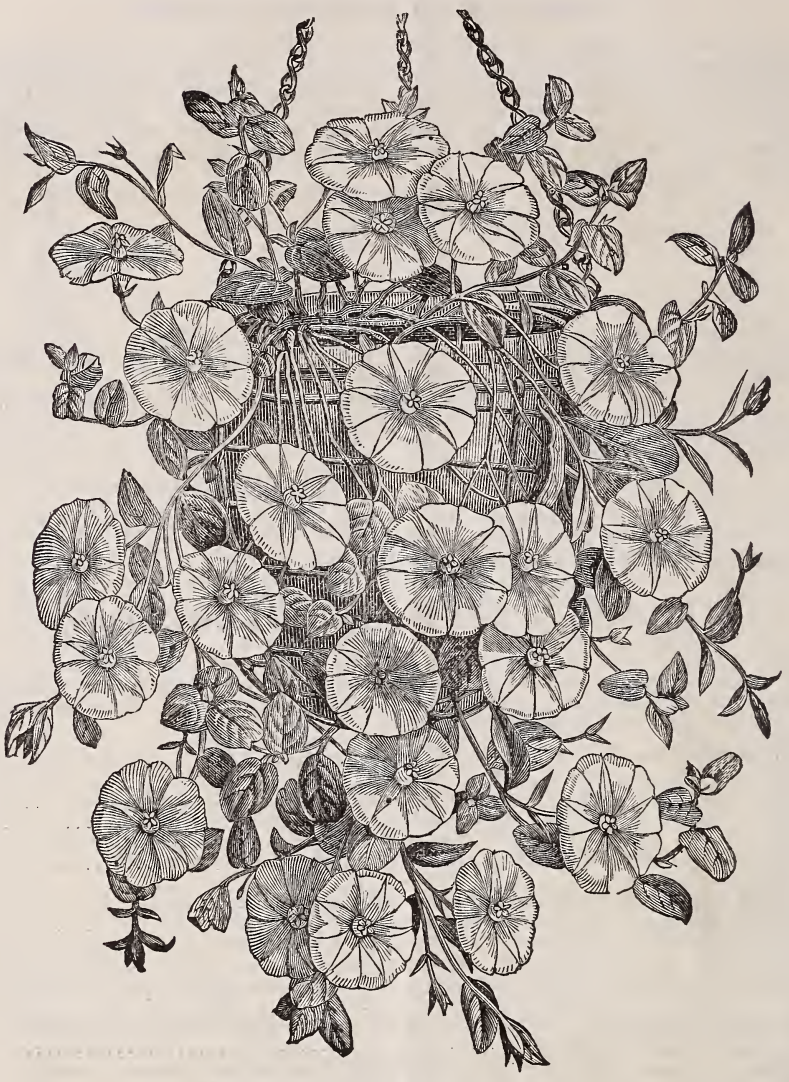

CONVOLVUS MAURITANICUS. No. 252.

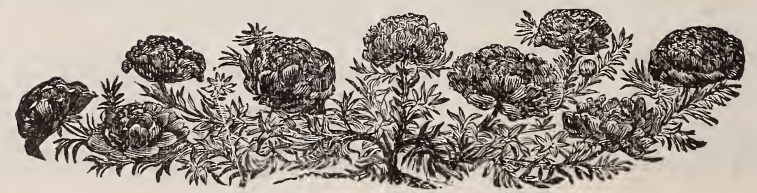

PORTULACA. (From Double Varieties.) 


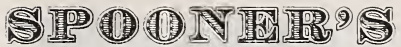

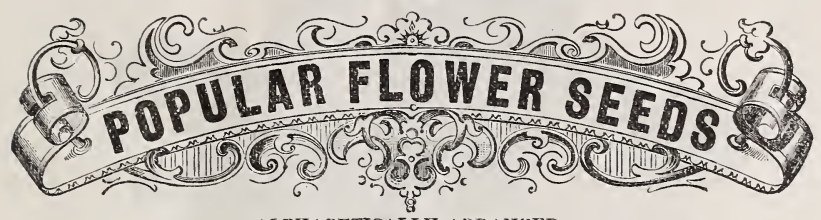

AI.PHA BETICALLY ARRANGED.

The information so briefly given with regard to duration, hardiness, and height of each plant is only approximative, as the local characteristics of soil or climate, North or South, or their cultivation in pots under glass, will vary in these respects.

Explanation of Abbreviations Employed.-A., Annual; B., Biennial; Bb., Bulb; C. Climber; E., Evergreen; G., Greenhouse; H. Hardy; Her., Herbaceous; H. H., Half-Hardy; St., Stove; S., Shrub; P. Perennial; T. Tender.

No.

1. Abobra viridiflora, $H$. H. P., a fine ornamental foliage climber............ 10

Abronia, neat dwarf-trailing plants, with verbena-like clusters of flowers; they are profuse bloomers, making a desirable feature of the flower garden throughout the summer; peel off the husk before sowing the seed, plant in light sandy soil.

umbellata, H.H.P., rosy lilac, white eye

Acroclinium, an elegant annual everlasting flower, rcsembling the Rhodanthe manglesii, but larger, fine for winter bouquets.

6. roseum, H. H. A., beautiful flowers, silvery rosc, 18 inches.............. 5

7. album, white...................... 5

8. Adlumia cirrhosa, II. A., (Hountain Fringe), a graceful climber, flowers pink and white in clusters, enormous grower, 15 fret............................ 10

Agerintum. II. II. A., desirable for beds or borders, frec flowering.

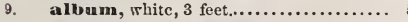

11. nexicanum, lavender blue, $1 \frac{11 / 2}{2}$ fect... 5

Agrostemma, pretty, free blooming plants, desirable for cutting.

13. coeli rosea, II. A., rosy purple, 1 foot. 5 Alonsoa, free flowering plants for the garden or house.

16. grandiflora, H. H. A., large flowered, bright scarlet, 2 feet................ 5

Alyssunu, (Siceet Alyssum) pretty, free blooming plants for borders or house.

20.

odo ratum, H.A., white, in clusters, very swcet, 1 foot, per oz. 50 cents...........

blooms the first season, 1 foot...........

No.

Price per Pkt.

Amaranthus, showy plants, desirable chiefly for their ornamental foliage.

24. bicolor, H. H. A., leaves crimson..... 5

25. bicolor ruber, II. H. A., fine rich foliage.......................... 5

27. cruentus, (Prince's Feather), II. H. A. dark purple, erect flowers, 2 feet....... 5

30. salleifolius, (Fountain Plant), H. II. A., plant pyramidal, leaves long, narrow and wavy, 2 fcet................... 5

31. tricolor, (Joseph's Coat), H.H. A.,red, yellow and green foliage, 2 feet.........

32. mnobium alatum, H. A., pretty,

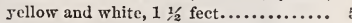

Anemone, beautiful carly spring flowering plant; soak the seed in moist soil until they sprout, when they should be planted.

coronaria, H. A., choice mixed.......

Antirrhinum, (Snapdragon), handsome free flowcring border plants, hardy perennials, blooming the first season if sown early.

45. Toun Thumb, fincst dwarf mixed..... 5

46. finest mixed, tall growing varieties... 5

Aquilegia, (Columbine), valuable plants for flower borders and rock work; pretty for cut flowers, blooming in the spring.

45. alba plena, II. P., double white..... 5

49. caryophyllsides, H. P., magnificently

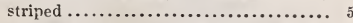

50. clarysuntha, II. P., from the Rocky Mountains, rich golden yellow........ 5

51. coerulea, II. P., from the Rocky Mountains, blue and white, bcautiful........

5ิ3. mlandulosa, II. P., true, large blue and white flowers..................... 5

1033. - vera, H.P., large blue, very beantiful 10 


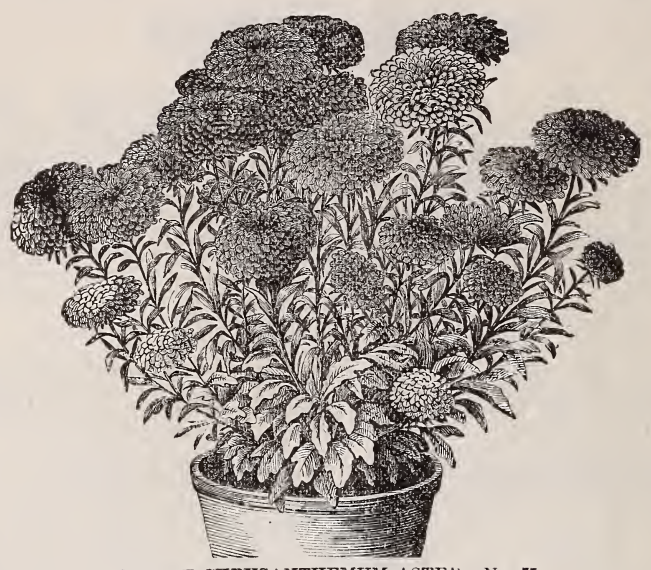

DW ARF CHRYSA NTHEMUM ASTEK. No. 77.

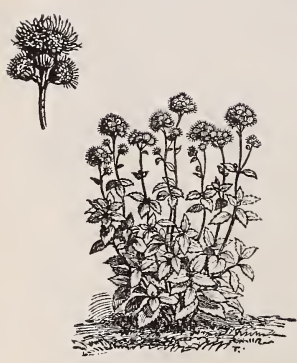

AGERATUM. No. 11 .

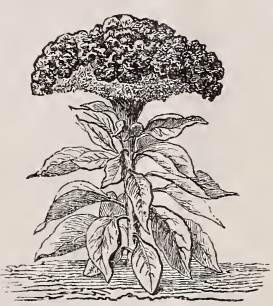

COCKSCOMB. No. 182.
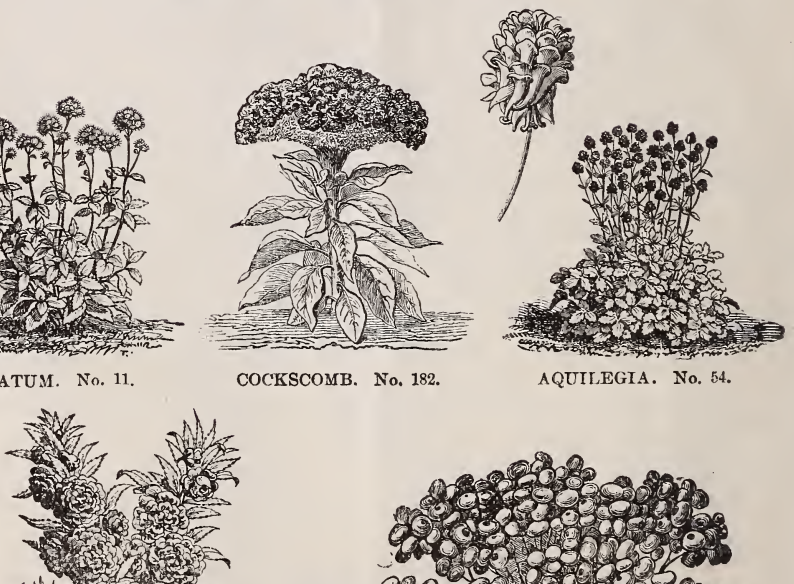
2. rint

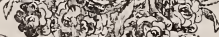
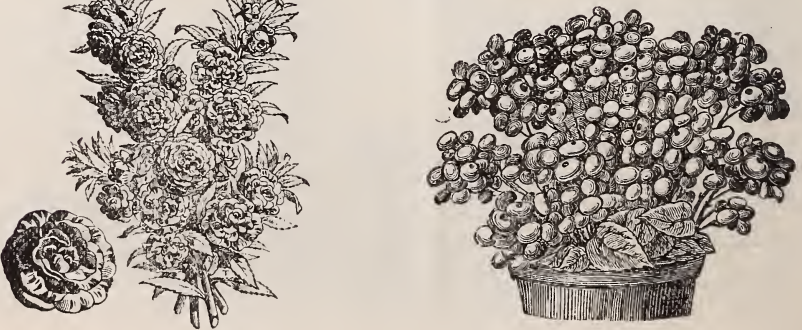

BAISAM. No. 112. 
54. Actuileria skinmeri, H. P., orange, searlet and crimson................ 5

55. mixed, double varieties .............. 10 A romeme, free blooming plants with l:trge flowers, resembling a single poppy.

58. graudiftera, II. A., latge white flowers.

59. mexicanum, U. P., yellow, fine...... 5

60. Arstolochia sipho, H. P., (Dutchman's Pipe), a beautiful climber with immense icaves, eurious shaped yellow and brown flowers, resenbling a pipc, 30 feet, 15

Aster, is one of the most popular annuals in eultivation. It delights in a deep rich soil, is benefited by a mulching of manure, the seed can be sown in a hot-bed or cold frame, the plants are easily transplanted to the open border.

61. Germun quilled, mixed..............

63. — Bedtece's hwarf bouquet, very free flowering, 8 inches.............. 10

66. Dy ramidal dwarf bouquet, the plaut forms a complete bouquet of fluwers 10

67. Truftiant' preony-flowered perfection, beautiful large flowers, petals reflexed, in bright rich shades, 18 colors

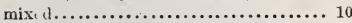

69. innbricated pompon, very fine,almost globulir formed, excellent for bouquets, 10 colors mixed..................... 10

70. tall chrysanthenum flowered, large flowers, 10 eolors mixed.......... 10

72. rose, large flowered, beautiful pyramidal flower, brilliant colors, 2 feet.......... 10

76. Giant Emperor, enormous flowers, pyramidal formed, brilliant colors, 2 feet 10

7i. Awarf chrysanthenum flow. ered, a splendid variety of compact habit, very dwarf with large flowers, 12 color mixel...................... 10

78. New ictoria, a splendid varicty about 18 inclics high, robust and compact, very large double flowers, mixed.......... 10

1070. mixed, double, various colors......... 5

104. IBalloon Vine, H. H. A., (Cardiosper. mum), flowers white, with inflated capsules, 4 feet.........................

Balsam, an old and popular half-hardy annual, produeing un abundanee of large double flowers; plant in a deep rich soil, start seed in a frame.

105. atrosanguinea plenissima, H. H. A., splendid blood red............... 10

106. camellia-flowered, German, very double, rich colors spotted, mixed, 2 feet 10

108. White, excellent for florist's use, 2 feet.......................... 10

111. rose-flowered, very fine, very double, mixed colors, 2 feet................. 10

112. wolferino, white striped and spotted carmine, beautiful, 18 inehes........... 10

115. double mixed rarieties, some semidonble fluwers.................... 5
No.

Price per Pkt.

117. Fachelors' battons, (Centaurea $C y$ anus), a showy, hardy annual in a great variety of colors, 2 fect...............

118. Bellis perennis, (Double German Daisies), H. H. P., border or pots; yields a good percentagè of double flowers..... 20

119. Begomia hybrida, S. P., finest mixed 20 974. tuberous rooted, mixed, slow in germinating, fine for bedding............25

122. Fo rachycome iberidifolia, (Swan River Daisy), H. H. A., very pretty, light blue, and white flowers mixed, 8 inches

Frowallia, exceedingly pretty plants for the house or for summer bedding.

124. elata, H. II. A., blue, white centre.... 5

125. - alloa, white.................. 5

126. Cacalia coccinea, (Tassel Flower), H. II. A., scarlet, fine for borders, 18 inches

132. Calenilula, (Cape Marigold), La Proust, H. A., free flowering, double nankeen colored........................... 5

133. pongeii fl. pl. (Hybrid Marigold), Н. A., double white....................

Calceola ria, brilliant flowered plants for conservatory for spring or summer decoration, the dwarf section is very dis. tinct and attractive.

134. hybrida granditlora, H. H. II., very large rich colored flowers, mixed colors, 20 inches................... 20

138̀. - nana, Iwarf, spotted, eompact habit........................ 50

Calliopsis or Coreopsis, a useful showy elass of plunts of rapid growth, effective in mixed beds or borders, of rich and striking colors.

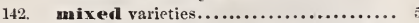

Callirhoe, handsome, saucer-shaped flowors, free blooming, for bedding or massing; steep the seed before sowing.

144. pedata mana, $H$. II. P., rich velvety erimson, white eye, 1 foot........... 5

Campanula, well-known and beantiful plants; if sowu early many of them will bloom the first season.

146. carpatica, H. P., light violet, large erect flowers, 1 foot... ............ 5

148. grandifiora, blue, fine variety, 2 feet.. 5

149. loreyi, H. A., blue and white mixed, 1 foot $\ldots \ldots \ldots \ldots \ldots \ldots \ldots \ldots \ldots \ldots \ldots \ldots \ldots \ldots \ldots$ o.

152. pyramidalis, II. P., blue and white mixed, 3 feet..................... 5

154. Canary Rirul Flower, H. II. A., (Tropaeolum Canariense or peregrinum) a popular climber, with beatufally fringed rich rellow flowers. Per oz. \$1. 10

Candytuft, very useful hardy anuuals for garden or house, sow seed where the plants are to bloom.

155. fragrant, pure white, swect, fine, 1 foot 5

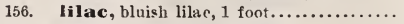
157. purple; 1 font................. 


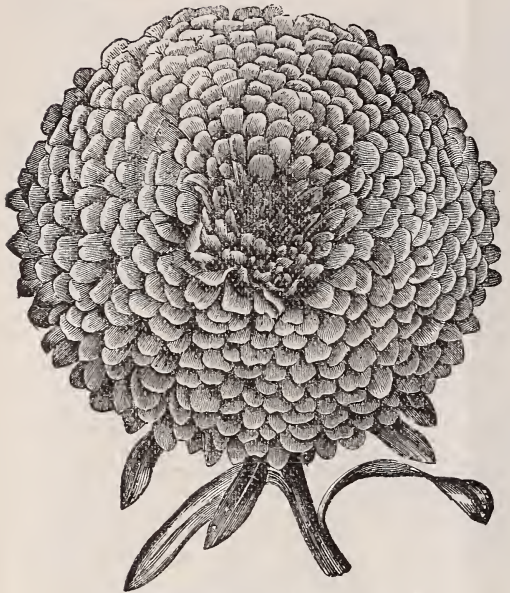

ASTER, PAEONY-FLOWERED. No. 67 .

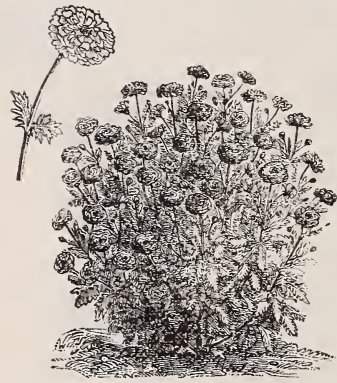

CHRYSANTHEMUM. No. 211.

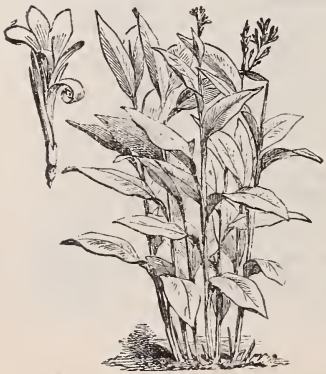

CANNA. No. 161

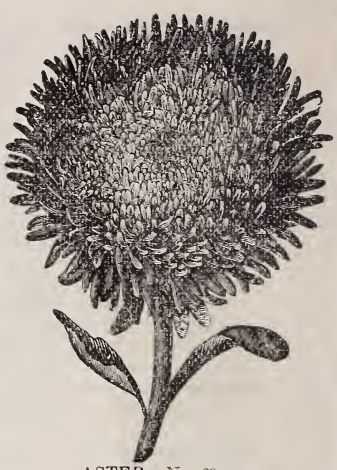

ASTER. Noo. 69.
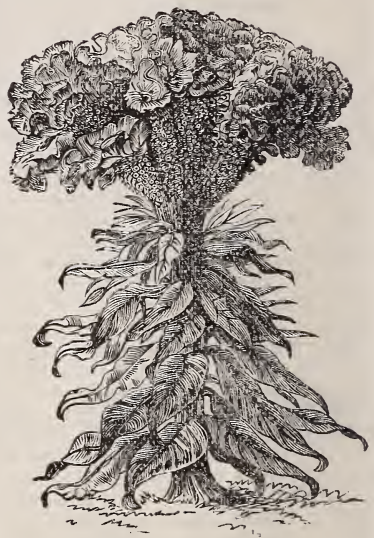

CLEOSIA CRISTATA VARIEGATA. No. 183.

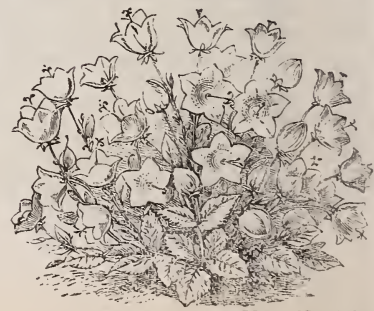

CAMIPAYULA CARPATICA. No. 146 
158. Candytuft rocket, pure white, in long

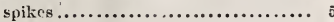

159. Dumnett's, dark crimson, beautiful, $1 \mathrm{ft} 5$ 160. white, 1 foot..................... 5

1037. various collors mixed, 1 foot, per oz. 25 cents...........................

Canna, (Indian Shot), a half-hardy perennial, but if sown early will bloom the first year. Camnas are very effective for giving a tropical aspect to gardens; soak the seed 24 hours, or until sprouted, be. fore planting.

161. compacta elegantissima, II. H. P., large, reddish yellow, 2 feet....... 10

162. indica, H. H. P., red, 2 feet......... 5

165. Warcewiezii, H. H. P., crimson purplish foliage, 3 feet................ 10

166. Sirue mix ed. per oz., 60 cents......... 10

Cunterbury Brell, the well-known popular bell-shaped flower of great beauty, free flowering, hardy biemnials.

174. doulb 1 e mixed all colors..............

175. single mixed all colors ............... 5

170. new foran, mixed (Campanula Calycanthema), blue and white, singular and pretty.......................... 10

Carnation, universal favorites, from their great beauty, delicious fragrance, and simple culture. They can be sown in the open ground in May; in the autumn the plants should be lifted and kept in a cool cellar. Plants grown from seed are usually more floriferous than those grown from cuttings; generally produce about 75 per cent. double flowers.

178. finest Italian mixed, H. H. P...... 25

180. English mixed, H. H. P........... 10

181. Catchfly, (Silene), H. A., pretty free blooming plants for beds or borders, of easy culture, fine mixed............. 5

Celosia, or Cockscomb, half-hardy annuals, are pretty and curious plants for the garden and for pots; the seed should be sown early in a frame, and treaterl with the most liberal culture. A very fine foliage plant.

182. cristata, fine crimson, $1 \frac{1}{2}$ feet........ to

183. - variegata, splendidly variegated very large heads, crimson and gold.... 10

185. aurea py ramidalis, fine golden color 10

186. coccinea pyramidalis, crimson

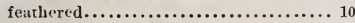

187. cristata Kermesina Tom Thumb, 5 to 6 inches high, forming large heads of crimson flowers................... 10

188. nama, Copper Chamois, splendid....... 10

189. Huttonii, a splendid bedding plant, beaniful claret-colored foliage......... 10

1038. japosica, (New Japanese Cockscomb), r.ry beautiful.................... 10

1039. cockscusmb, mixed............... 5
No.

Centaurea, very desirable for beds and borders, start early under glass.

191. clementei, H. P., robust species, silvery foliage..................... 20

192. candidissima, H. H. $P$., fine silvery foliage, broad cut leaf..............20

193. gymnocarpa, II. A., very graceful, silvery gray foliage................. 15

202. Chelone barlbata coccines, this plant forms a tall summer growtl of six or seven feet, with graceful spikes of brilliant scarlet flowers............. 5

208. Chinese prin mose (See Primula), finest mixed............................. 50

Chrysanthemum, an old well-known plant. The annual varieties are desirable for summer flowering in the garden, and for pot culture, quite distinct from Indicum, the brilliant hardy perennial autumn flowering sorts.

1041. vingle mixed, $\mathrm{H}, \mathrm{A} \ldots \ldots \ldots \ldots \ldots \ldots \ldots$. 5

211. Rouble, yellow ......................

212. - white........................... 5

214. Indicum, H. P., large flowered donble varieties......................... 10

215. —uanum, (Pompon), very double.... 10

Cineraria, a popular greenhouse plant, blooming during the winter and spring, sow the seed in the spring for winter blooming plants, and in mid-summer for a later bloom.

216. hylb rida, G. P., saved from fine varieties 25 218. maritima candidissima, H. H. P., splendid silvery foliage.............

219. mantitima, H. H. P., handsome white foirage..........................

976. Lcanthifolian, new, silvery leaved, delicately cut, a great acquisition for borders 10

CIarkia, very pretty garden plants growing in any common soil; sow in the early spring or fall.

222. single varieties, mixed..............

1040. double varieties, mixed...............

224. Clianthus Dampierii, (Glory Pea), G. S., this splendid plant from Australia, his flowered finely when sown early in a frame, otherwise treat as a greenhouse biennial, splendid dark red and black pea-shaped flowers, very effective..... 20

Clintonia, an elegant dwarf densely com. pact growing plant, vieing with Lobelia Erinus, in beauty and brilliancy of color. It is finely perfumed.

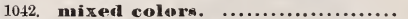

229. Cobea Acanderas, II. H. P., of very rapid growtl, with bell-shaped flowers beautiful foliage. Sow the seed edgewise, covering with light soil. Per oz. $\$ 3$. 10

495. Convolvulus M Major, H. A., (Morning Glory), rapid growers, with handsome flowers in beautiful colors, grow any. where, 15 feet, fine mixed, per oz. $20 \mathrm{cts}$. 


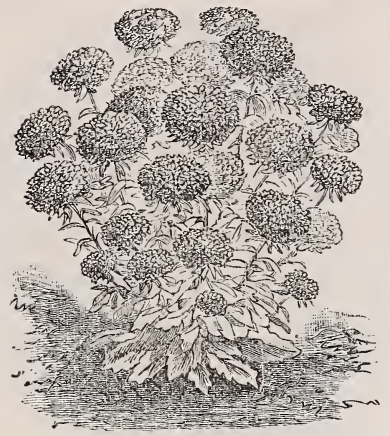

ASTER VICTORIA. No. 78.
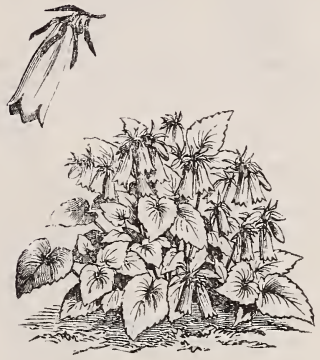

CAMPANULA NOBILIS. No. 151.

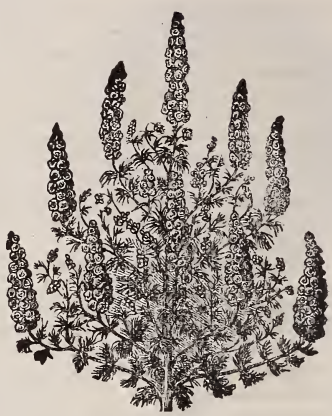

LARKSPUR. No. 421 .

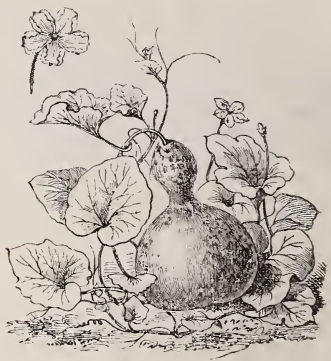

GOURD. No. 362 .

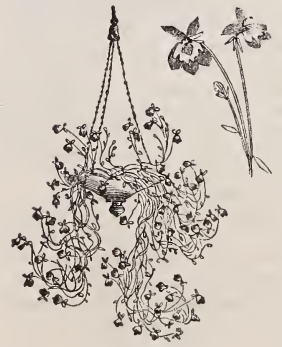

CLINTONIA

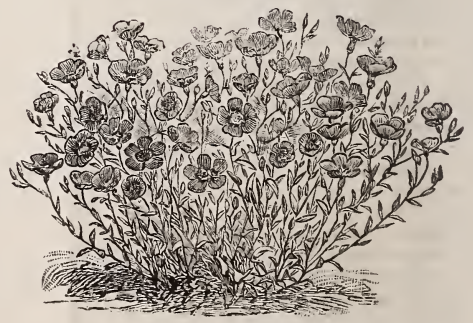

LINUM, No, 435. 
Convolvulus, (Duary Morning Glory), are free flowering showy dwarf traling plants, producing a brilliant effect.

246. tricolox min 252. -maturitanicus, H. II. P., violet blue for rockivork or baskets, profuse bloomer 10

253. -cantabricas stellatus, H. II. P., - pink, white star in eentre, for beds or hanging baskets.................. 10

257. Cucurbita lagenaria grgantea, Sugar Trough Gourd. See Gourd...... 10

Cyclamen, beautiful plants with elegint variegated foliage, and very attractive flowers. They are plants of easy eulture, profuse bloomers from November until May. Seed sown the last of January will produce niee plants and flower in November, if kept in a vigorous state of growth from the start.

261. persicum, G. B., mixed fine......... 25

262. —orandfloram, Welch and Edmonel prize struins .................... 50

Cypress Vine, II. II. A., (Ipomea Quamoclit), delieate fern-like foliage, with a profusion of star-shaped flowers, should not be sown very early out of loors, soak the secd before sowing.

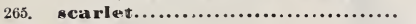

267, white.......................... 5

268. fine mixed, per oz. 50 cents......... 5

Datura, this is an easily grown plant, remarkable for its fine foliage and immense trumpet-shaped flowers. Sub. tropieal in effect, flowers the first year from seed if sown early. Preserve in sand during the winter in a dry eellar.

2\%o. fastuosia hulberiana, fine varieties, mixed double....................... 10

2i6. meteloides, or Wrightii, white bordered lilae, sweet seented, in bloom from July to November, 2 fect............ 5

Delphinium, eommonly known as Larkspur, is a useful free flowering plant; if sown early will flower the firet season.

281. Clatum, (Bee Larkspur), blue dark eye j 282. Cormosum, II. P., dark blue and white fine spikes..................... s

283. nudicanle, II. P., searlet, very fine.... 10 284. imperialis, pl., (Emperor Larkspur), rery fine, of symmetrical growth, brillaant eolors mixed................... ;

976. cashmerianum, (New), large flowers, dwarf habit, eolor rich light purple, shaded dark blue.................. 15

Digitalis, (Foxglove), an ornamental and showy plant, useful for garden purposes.

298. purpurea, H. B., purple spotted, 3 feet 5 299. gloxinoides, improved large flowered Gloxinit-shaped blossoms, 3 feet....... 5

300. Intea, pale yellow................. 5 301. Every's, new spotted, beautifully spotted 5 1046. very fine mixed.................... 5
GDiant hus Ginensis, (Chinese or Indian Pink), are among the most beautiful bedding plants from seed. If sown early under glass and planted out, will bloom from June to late autumn, or sown in May in the open ground will soon make a fine display. The flowers range in all colors from white to deep crimson and lilie.

285. dentosus hyloridus, plants of dwarf, compact habit, suitable for edgings, rock. work, mixed colors................. 10

286. chimensis, II. B., single mixed, many colors, showy for bedding............ 5

287. - double mixed, various colors, good pereentage of double flowers.......... 5

288. — - white, pnre white, 1 foot........ 5

289. gardnerianus, $\boldsymbol{H}$. B., fine fringed double flowers, erimson of varions shades, fragrant, blooming the first year.............................

290. heddewigii, II P., Japanese varieties, flowers very large in the richest variety of colors, mixed.....................

291. -fl. pl., double in above shades, very showy mixed...................... 10

292. -diadematus, fl. pl., (Diadem Pink), double, in many shades of color, plants of dwarf eompact habit............. 10

977. —atropurpureus, fl. pl., double, very large dark blood-red flowers.... . 10

294. laciniatus, II. B., very large and beautifully fringed flowers, finest mixed colors ............................

295. — fl. pl., saved only from the finest double varieties, beautiful colors, mixed. 10

1043. —_ striatus, fl. pl., a large double variety with white flowers, striped and streaked in various shades, mixed...... 10

293. imperialis, fl. pl., II. A., (Double $\mathrm{Im}$ perial Pink), beautifully variegated, finest mixed... ................... 10

1044. — fl. pl., double white.............. 10

1045. - - purpareas striata, white striped, purple.................... 10

296. Dlumarius, II. P, (Pheasant's Eye), pretty single pinks, with white flowers and fringed edges, 1 foot.............

297. Didiscuz carrulens, II. H. A., lavender blue, pretty plant from Australia... 5

Erysimum, showy free-flowering plants, with elusters of fragrant orange or yellow fluwers, resembling a wall-flower.

312. arkansanum, $H$. A., yellow $1 \frac{1}{2}$ feet 5 313. perofiskianum, deep orange, showy, $11 / 2$ fect......................... s

Wschscholtzia, a beautiful annual with fine deeply eut foliage, profuse bloomers, sow the seed where the plints are to bloom.

316. californica, II. H. B., bright yellow, darker ernter 1 foot................ 5 


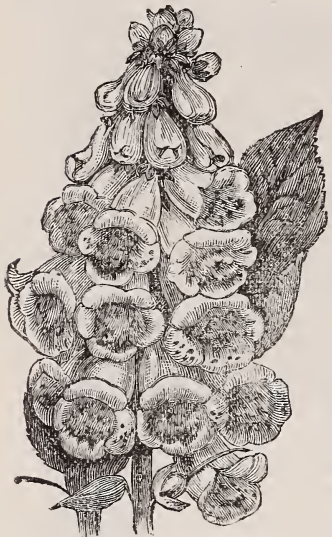

FOXGLOVE. No. 301.

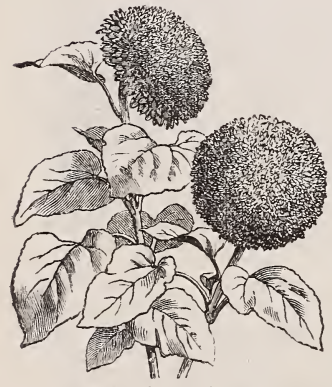

HELIANTHUS. No. $33 \pi$.

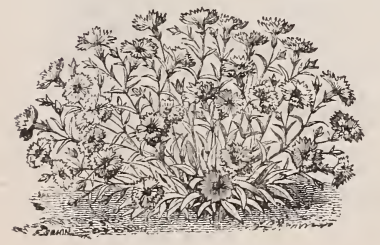

DIANTHUS. No. 285.
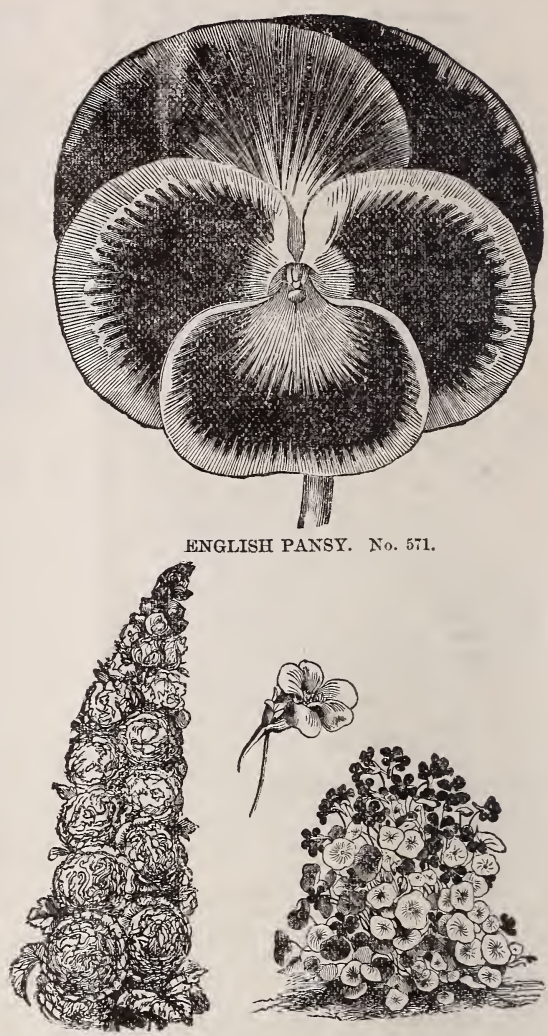

HOLLYHOCK. No. 392.

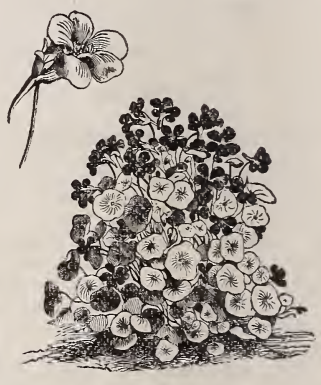

NASTURTIUM. No. 519.

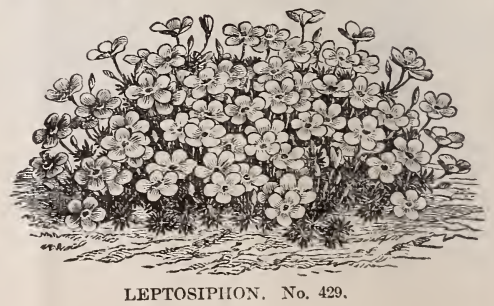


No.

317. Wschschsltzia crocea, orange, dark in centre, 1 foot.................... 5

318. -alba, creamy white............. 5

1047. —otriata, orange, striped lemon, fine. 5 1048. mixed, various colors................. 5

Evening Primnose, a desirable border plant.

323. oenothera biennis, H. P., yellow, if sown early will bloom first year, 1 foot 5

319. Euphorlia va riegata, H. II. A., foliliage margined pure white $\ldots \ldots \ldots \ldots \ldots$.

Fraxinella, (Dictamnus), an ornamental genus of plants deserving extensirc cultivation. The leaves when rubbed emit a fine odor like lemon-peel.

330. white, H. P., 2 feet............... 5

331. reei, 2 fect...................... 5

499. Forget-Vire-Not, see Myosotis....... 10

298. Foxglove, see Digitalis.

332. French Hitoneysuckle, (Hedysarum), a desirable free-growing border plant from Italy, II. P., red and white........

Gaillardia, splendid plants for a brilliant display in the flower border, their large handsome blossoms keep expanding until killed by frost, desirable as cut flowers.

1049. alba maroinata, H. H. A., white edged, $11 / 2$ feet.................... 5

337. grandiffora Inybrida, rich crimson and yellow........................

338. pictan or painted, red and ycllow, 1 foot.. 5

1050. Josephus, brilliant red and orange.... 5

1051. fine mixed varieties ............... 5

340. Gaura Hindheimeri, half-hardy annual of delicate graceful habit, with spikes of white and reildish flowers, free

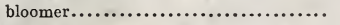

1052. Gillia, pretty free flowering dwarf plant, blooming in almost any situation, fine

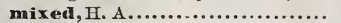

Geramium, (Pelargonium), old garden favorites for beds or house culture, seedlings always produce prolific flowers.

343. fine mixed. G.P., from a large collection 20 314. mixed tricolor, fine, only a portion will show variegation at first.......... 50

998. odoratissimum, (Apple Scented), leaves very sweet scented............25

351. Cradiolus, finc Hybrids from Ganda. vensis, saved from my unrivalled collec. tion of prize rarieties, mixed........ 15

Globe Amaranthus, (Gomphrena), sow under glass, and transplant to border.

356. mixed, finest varieties everlasting.....

Godetia, a genus deserving extensive cultivation. Their profuseness of bloom and delicate tints of color, render them universal favorites.

358. lindleyana, H. A., rose, purple spotted, 2 feet.................... 5

359. Tom Thumb, fine dwarf variety, 1 foot 5 361. Whitneyi, crimson and blush, fine, $1 \mathrm{ft}$. 5
No.

Price per Pkt.

360. Godetia, Whe Bride, beautiful cupshaped blosoms, white and crimson, very pretty, 2 feet...................... 5

979. Lady Abermarle, superb, flowers very large, intense crimson carmine.... 5

1053. very fine, mixed................. 357. Gloxinia, this genus forms one of the most effective and beautiful groups of dwarf summer flowering bulbs. St. P., in three kinds, viz : erecta, horizontalis, and pendula, mixed in unsurpassed colors 20

Fourd, rapid growing ornamental plants with curious shaped fruit, abundance of foliage.

362. hottle, T. A.................... 5

363. Hercules Club,............... 10

364, flat Corsican, $\ldots \ldots \ldots \ldots \ldots \ldots \ldots \ldots \ldots, 5$

365. orange, in the form of an orange..... 5

369. powder Bnorn, ................. 5

257. Sugrar Trough, (Cucurbita Lagenaria Gigantea), grows to an immense size, roundish form, can be used for many household purposes............ 10

757. trichosanthes colubrina, true serpent Gourd........................ 5

368. fine mixed....................... 10

Gypsophila, free-flowering plants, very desirable for rock-work and the garden.

370. muralis, II. A., rose, very pretty, dwarf $1 / 2$ foot............................

371. paniculata, H. P., (Baby's Breath), small white flowers in great profusion, for bouquets or as everlastings........ 5

Felianthus, (Sunflower), a well-known plant of majestic growth, with brilliant flowers of immense size.

275. argophyllus, H. A., yellow, double, silky.like foliage, 5 feet ............

376. califurnicus, large, double orangecolored flowers, 5 feet................ 5

377. globosus fistulosus, the finest very large double flowers, bright saffron color 10

379. Irammouth IRussian, enormous single flowers....................

1054. common siugle suntlower, usual:y grown for the seed, per oz. 10 cents.... 5

Helichrysum, (Elichrysum), free flower. ing, effective for borders, one of the best everlastings.

380. bracteatum $H$. H. A., golden ycllow 2 fcet............................ 5

1055. monstrosum, double mixed, 2 feet... 5

1056. nan um, finest dwarf, mixed, 1 foot..... 5

Heliotrope, deliciously fragrant, and are equally prized for house or garden culture. Plants will bloom the first year from seed.

388. choice mixed, H. H. P .......... 10

H umea, a magniftcent and showy plant, blooming through the summer and antumn.

395. elegans, H. H. B., amaranth brown.... 10 


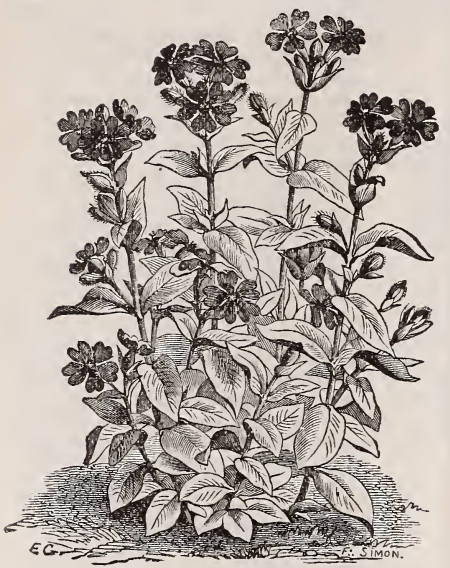

LYCHNIS. No. 458.

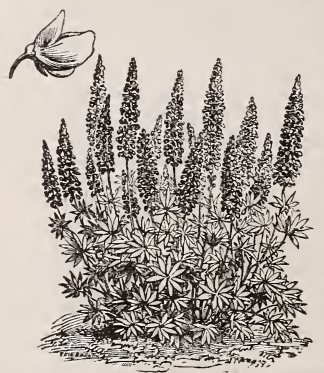

LUPINUS. No. 4.54 .

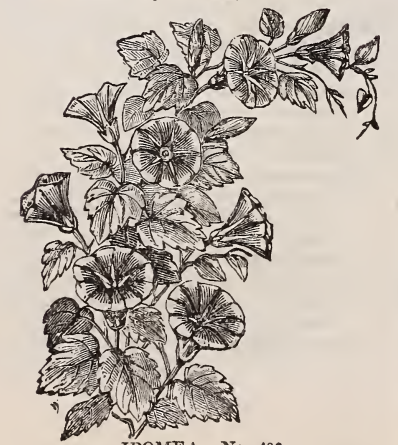

IPOMEA, No, 406 .

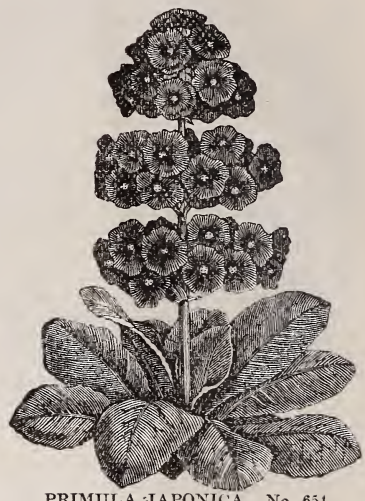

PRIMUI,A JAPONICA. No. 654.
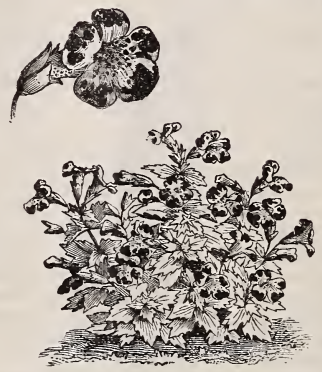

MIMULUS.

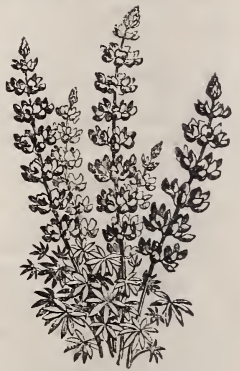

LUPINUS. No. 453

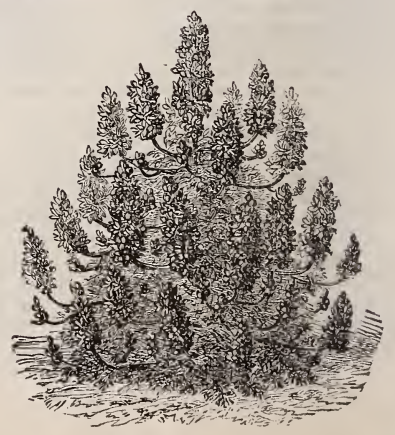


No. I'rice per Pkt.

Hollyhock, a sliowy hardy biennial for decorative gurden purposes, seed sown early in the spring under glass, will bloom the first season or in July and $\mathbf{A u}$ gust, will make nice plants if slightly protected during the winter to bloom the following year.

392. Wlendid mixad, from the best English collection..................... 10

394. Honesty, (Satin Flower), Lunaria biennis, a hardy biennial, flowering the second year in May and June, the flowers are fucceeded by semi-transparent seed vessels that are quite ornamental; will keep a iong time..................

Lberis, (Perennial Candytuft), profuse bloomers adapted for beds, rock-work or baskets, blooming early in the spring.

399. vempervirens, $H$. P., pure white, evergreen habit, $1 / 2$ foot..................

401 Ice lant, a pretty trailing plant with fleshy leaves, having the appearanee of being coated with ice.................

Ipomea, desirable for pots and baskets, and for house or garden; start the seed in a hot-bed.

980. bona mox, (Good.Night or Evening Glory), T. A., violet, very large fragrant blossoms, expanding in the evening, 10 to

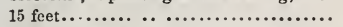

406. limbata elegantissima, large violet flower, pure white margin, fine.........

coccinea, (Star Ipomea), small scarlet flowers.............................

Lantana, ore of the finest bedding and conservatory plants, with verbena-like heads of brilliant flowers in varied hues of color.

418. finest French varieties mixed, H. H. P.. 10

Larkspur, (Delphinium), one of the most generally cultivated plants, profuse bloomers, effictive in beds.

419. donble dwarf rocket (Hyacinth Flowered), II. A., fine mixed..........

4:20. —_ stock flowered, long spikes of bloom..........................

121. candelabra flowered, branching to the ground, beautiful double flowers, $1 \mathrm{ft}$. 5

Lathyrus Latifolius (Everlasting $P e a$ ) II. P., frec-flowering plints with showy flowers, for covering stumps, fences or walls, flowers without fragrance.

42 . scarlet or crimson...................

425. albus, white.................... 10

428. Lavendula epica, (Lavender), H. P., enlivated chiefly on account of the delicious fragrance of its leaves.............

Linum, an effective and showy bedding plant, a continuous bloomer.

435. grandiflorum coccineum (Scarlet Flax), H. A., brilliant crimson, dark centre, fine foliage, delicate stem, 1 foot
472. Leptosiphon hybridas, pretty freeblooming annuala, for rock-work thd

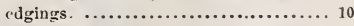

981. Linaria cynaballaria, (Kenilworth or Coliseum Ioy), II. P., an old fatvorite, pretty banging plant................ 10

Lobelia, a most elegant and useful genus of dwarf plants, of easy culture, well adapted for bedding, edging, pots, or rockwork; the seeds being vers smaL should be corered lightly.

441. cardinalis, (Cardinal Flower), H. P., the well-known native, bright scarlet... 5

447. Gracilis, H H. A., slender, pale blue.. 5 448. - alloa, white variety of the abore... 5

451. Lophospermura ncandens, II. II. C., cffective for grecnhouse or garden, with showy fuxglore-like flowers, rosy purple............................ 10

452. Love Lies Dleeding, (A maranthus Caudatus), II. A., lons drociping racemes of blood-red flowers, 3 feet........ 5

Lupinus, a splendid genus of ormanental free-flowering garden plants, sow the seed where they are to remain.

453. annual, mixed.................... 5

454. perennias, mixed.............. 5

Lychmis, this fine genus is indispensable wherever herbaceous plants are grown; of easy culture.

456. Chalceflonica, II. P., scarlet, from Kuscia, 2 feet................... 5

457. — allba, white, 3 fiet............ 5

458. haageana hylorida mixed, H.II.P. large flowers, ranging in eolor from white, rel, scarlet, orange, 1 foot..... 10

Milope, handsome plants, of branching labit, producing their large flowers in great abundance.

461. grandiflora, H.A., crimson purple, 3 fi. 5

462. alba, whitc, 2 feet.................. 5

Marigold, (Tagetes), one of the most raluable and effective of bardy annuals, with brilliant double flowers.

464. A frican. H. H. A. mixed quilled..... 5

468. Tall double, French mixed......... 5

1057. dwarf doalbe, French mixed........ 5

Narvel of Eeru, (Nirabilis Jalapa), a well-known g.urden f.rvorite, eommonly called, Fourmo'clocks.

472. fine mixed colors, H. 11. H., 2 feet.... 5

657. Matricaria parthenium (Feverfew). -See Pyrethrum.

Maurandia, charming elimbers with elegaut flowers and foliage, snitable fur baskets, trellises or house culture, start seed in a lot-bed.

497. fine mixed, II. II. P.............. 10

Megembrianthemum, dwarf growing annuals, of great beauty.

480. Tricolor, (Dero Plant), H. H. A., deep rose, purple center, $3 / 4$ foot........... 5 

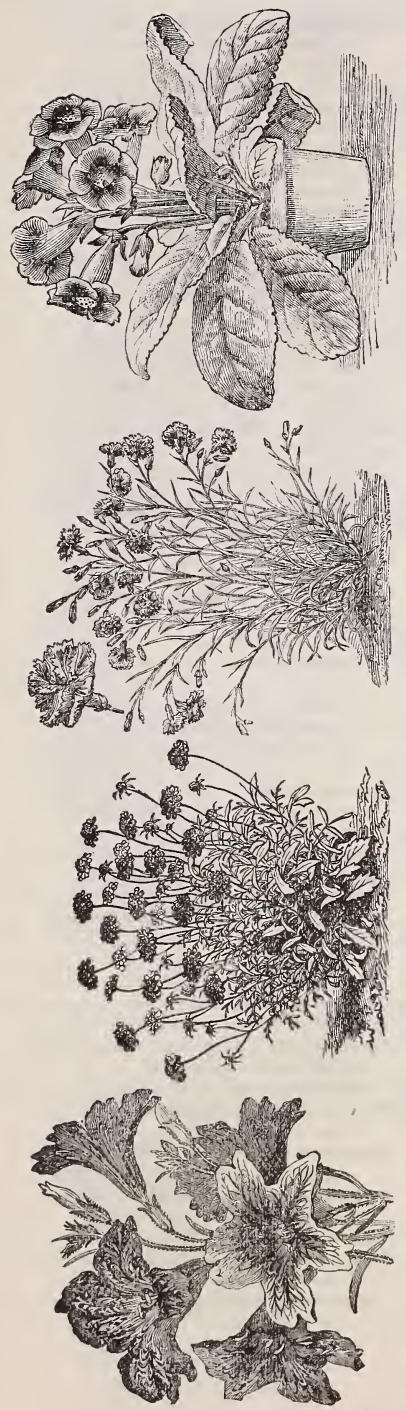
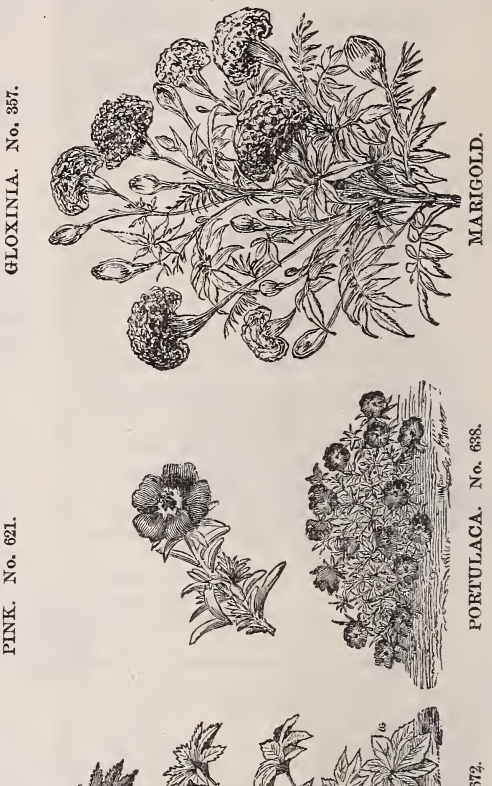
Wot Hen

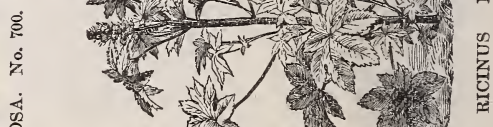

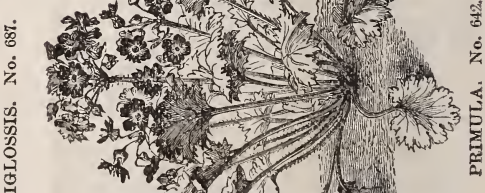
5) ( , 
No.

Migmonette, (Reseda), a well-known fragrant favorite of the garden. When sown in the open ground plants should be thinned out to produce larger bloom; sown ill pots at any time for succession in the house.

493. odorata, (Sweet Mignonette), H. A., very fragrant, per oz. 20 , per lb. $\$ 1.50 . .5$

982. graudiflora ameliorata, very large, orange rcd flowers.................. 10

486. Parson's white, flowers nearly white 10 487. crimson giant, very robust, brighter than the common, per oz. 20 cents...... 5

983. Milew' new hybrid ppiral, dwarf and branching, its fragrance is remark. able.............................. 10

709. Mimosa pudica, H. H. A., see Sensitive Plant.

Mimulus or Monkey Flower, showy profuse flowering plants for the garden and greenhouse; will bloom from seed the first year.

491. superl, mixed varieties, H. H. P...... 10

494. moschatus, (Irusk Plant)............ 10 495. Morning CHory (Convolvulus Major), H. A., rapid growing climbers with profuston of flowers in beautiful colors, 15 feet, fine mixed, pcr oz. 20 cents....... 5

700. Nourning Iride, see Scabiosa.

Myosotis, (Forget-me-not), charminglittle plants with a profugion of star-like flowers, for house or out.door culture, blooming the first year from secd.

499. alpestris alba, white, 6 inches.... . . 10 501. palustris, (the true Forget-me-not), bluc, 6 inches..................... 10

Nasturtium, (Tropaeolum), fine climbers, will grow any where, with a profusion of flowers of the most delicate shades of yellow, scarlct, striped, mixed, black, brown, and lcmon color, fine for baskets or vases; any one who saw the collection exhibited by me last autumn, before the Massachusetts Horticultural Society, will appreciate all that can be said in praise of their bcauty; both classes should be planted for the most perfect effect of color; my collection is unequalled.

503. tall, dark crimson, per oz. 25 cents..... 5 504. Dunnett's, orange, fine............. 5 \$605.1 1 Scheuermannianum, straw color, spotted brown.................... 5

506. - carneum, flcsh color........... 5

507. Schillingii, ycllow striped.......... 5

985. Schulzii, dark foliage, brilliant deep crimson........................... 5

986. TRegelianum, purple violet......... 5 987. , King Theodore, (new), very dark.. 5 1071. / Luteum, fine ycllow, new............ 10 1072. I Hemisphericum, (new), fine...... 10 The above collection of 10 varieties, $33 \mathrm{c}$.

508. fine mixed, various colors, per oz. 20c.
No.

Nasturtiom. Tom Thumb, (Droarf varieties), are admirable bedding plants, containing many delicate colors not found in the tall varietics of Nasturtiums.

509. _ coerulea rosea, H. H. A., flesh

colored rosc....................... 5

510.

511.

512 .

513.

514.

515 .

516.

517.

518.

992.

519.

- crimson. . . . . . . . . . . . . . ........

- rose, very finc................... 5

spotted king, vcry bright yellow,

blotched .......................... 5

_ beauty, yellow flushed vermilion.. 5

- Crystal Palace gem, sulphur

spotted mauve......................

King Theodore, nearly black... 10

— king of, most brilliant scarlet..... 5

- pearl, nearly white.............. 5

- golden king of, bright yellow.... 5

- ruby king, pink shaded carmine... 10

- one packet each of the above eleven varieties for 45 cents.

- mixed, various colors, per oz. $40 \mathrm{cts}$.

Tropaeolum Lobbianum, stronger growers than tha tall Nasturtiums, with very showy foliage and flowers.

520.

521 .

522.

523.

524.

525.

526.

$52 \pi$.

528.

529.

988.

989.

990.

991.

- Garibaldi, orange, finc...........

-Caroline Schmidt, scarlet......

Couleur de Bismarck ......... 5

-Geant des IBatailles, carmine.. 5

- Hilli Gehmidt, crimson...........

- Mons. Colmet, ycllow and crimson

- Tapoleon TII., vermillion, striped

scarlet $\ldots \ldots \ldots \ldots \ldots \ldots \ldots \ldots \ldots \ldots \ldots \ldots, 5$

Queen Victoria, stripcd, fine.... 5

Von Moltke, deep rose... ........

_Zanderi Nigra, very dark crimsou

maroon ........................... 10

-brilliant, very bright........... 5

-Crown Prince of Prussia,

bright deep blood rcd, one of the bcst,

very strong grower (new)............ 10

- Lucifer, dark foliage............ 5

- 1 pitfire, scarlet, profuse bloomer.... 5

The above collcction of fourteen beau. varieties for 55 ccnts.

530. - very fine mixed, per oz. 60 c.....

1058. Nemesia, exceedingly pretty and profuse blooming plants, useful for edgings and rockwork, fine mixed, H.H. A........

Yemophila, (Grove Love) a eharming and useful genus of dwarf growing annuals, with flowers of brilliant colors; is very pleasing and effcctive.

1059. mixed varieties, $H$. A.............

Vie rembergia, superb ornamental plants for clumps, edgeings, rockwork or hang. ing baskets; most profuse blooming. which it docs quickly from seed.

541. gracilis, H. H. P., whitc vined lilac, 1 foot..............................

Nigella, (Love in a mist), free blooming annual, with curious looking flowers.

542. damancena, $H$. $A$, dark blue, $1 / 2$ foot

5

5

5

5

(1)

5

5

5

5

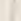

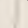

1

4




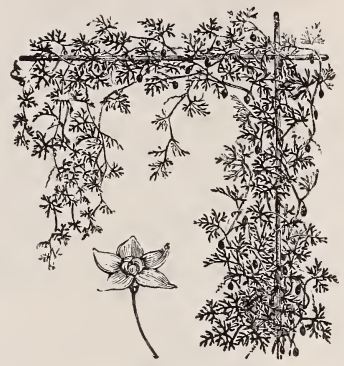

ABOBRA. No. 1.

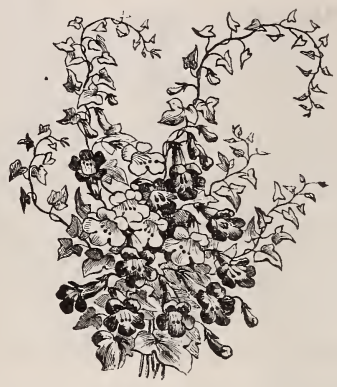

MAURANDIA. No. 479.

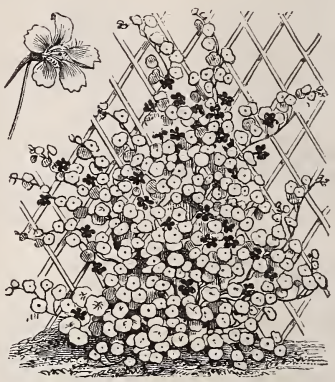

NASTURTIUM. No. 508.

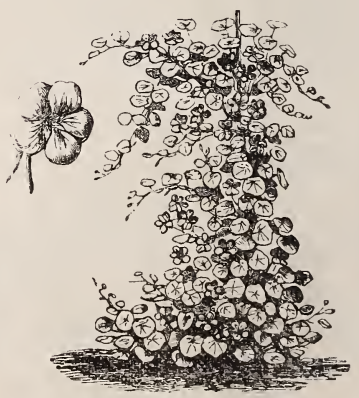

TROP FOLUM. No. 530.

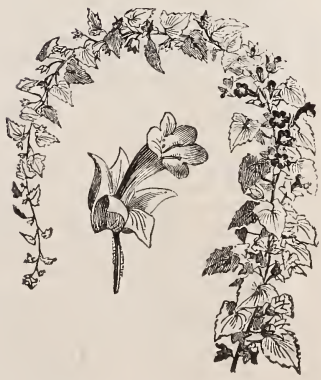

LOPHOSPERMUM. No. 451. 
No.

554. Enothera grandifiora lamarkiana, H.' B., very showy, large fra. grant yellow flowers, 4 feet..............

Dxalis, elegant flowering plants for the greenhouse or parlor.

556. rosea, H. H. P., delicate, rosy purple colored blossoms.....................

55ว7. tropaeoloides, T.A., yellow, very effective, dark foliage, $1 / 2$ foot...............

558. valdiviana, H. A., bright yellow, very pretty, sweet sccnted..................

Pansy, or heartease, is matchless in the curious beauty of its flowers, which are in their greatest beauty in May and June when the weather is cool. Sow the seed in frame or ground in the spring or in August, in the winter protect the plants in a frame or with evergreen boughs.

560. gold margined, beautiful .......... 10

561. golden yellow, very fine........... 10

562. marbled, purple $. . . \ldots \ldots \ldots \ldots \ldots \ldots . . .10$

563. white, fine....................... 10

564. violet, bordered white............... 10

565. Faust, or King of the Blacks, very fine 10

367. Dalier, or five blotched, beautiful, large

dark spots on cach petal.............. 20

570. Eelgian, or fancy, fine class, very large 20

574. Emperor William, ultramarine blue 20

568. French, fine mixed............... 10

569. " good mixed............... 5

571. Englis h, choice from named plants, flowers very large, and perfect in form and color ............................. 50

Paparer, (Perennial Poppy), an ornamental genus of plants, with large flowers of rich and striking colors.

575. bracteatum, H. P., large, deep red, spotted back, 3 feet...................

577. orientale, H. P., orange red, spotted back, 2 fcet ........................

Peas, Sweet, H.A., sow them thickly, as early in the spring as possible, four or five inches deep, they will come slowrer at this depth, but will bear the dry weather better.

580. mixed, various colors, per $1 \mathrm{~b}$. $\$ 1.00$, per oz. 10c.............................

581. Painted Lady, rosc and white, per lb. $\$ 1.50$, per oz. 10c....................

583. purple, striped white, per $1 \mathrm{~b}$. $\$ 1.50$, per oz. $10 \mathrm{c} . . . \ldots \ldots \ldots \ldots \ldots \ldots \ldots \ldots \ldots \ldots \ldots$.

584. acarlet, per lb. $\$ 1.50$, per oz. $10 \mathrm{c} . .$.

5\$5. — - w riped white, per $1 \mathrm{~b}$. $\$ 1.50$, per oz.10c............................

586. white, per lb. $\$ 1.50$, per oz. $10 \mathrm{c} . . . . .$.

587. Scarlet Invincible, deep scarlet, per lb. $\$ 1.50$, per oz. $10 \mathrm{c} . \ldots \ldots \ldots \ldots \ldots \ldots \ldots$

588. Black Invincible, very dark, per lb. $\$ 1.50$, per oz. 10c...................

589. Crown Princess of Prusaia, deli. cate blush, fine, per lb. $\$ 1.50$, per oz. $10 \mathrm{c}$.

424.
No.

Price per Pkt.

Penstemun, one of the best perennial plants for the border, the flowers are large, the markings beautiful, the colors rich and varied, the cultivation simple; an admirable plant to cut from.

590. mixed, very fine, 2 fect............ 10

591. Perilla Nankinennis, II. II. A., distinct and effective plants, foliage dark olive, or mulberry, at maturity a purplish black..........................

Petunia, a profuse bloomer for out-door or house culture, distinguished for the brilliancy and variety of its colors; the striped, blotched, fimbriated or fringed varieties are particularly attractive.

593. grandiflora, H. H. P., finest mixed, from largest flowcrs............... 10

596. - marginata, green margined, fine 10 994. fimbriata, single fringed varieties, very beantiful, in various colors.......... 15

995. —— fl. pl., double fringed, splendid, good percentage of double flowers..... 25

598. Spooner's hylorids, striped and blotched, fine...................... 10

600. Countess of Ellsmere, deep rose, pure white throat................... 10

601. very fine, mixed................... 5

602. extra choice, mixed.............. 10

603. —_ a louble, good percentage

of double flowers....................25

997. Hybrida, nana compacta multifora, : dwarf sort, from 6 to 8 inches high, color most brilliant, cherry red, marked with a white star, prolific bloomer 25

605. Phacelea conjesta, II. A., an inter. esting plant, good for honey.bees, color beautiful azure blue 2 feet.............

606. Phaseolus Ca racalla, this handsome elimber, with its long Wistaria-like flow. ers, is very effective for the conservatory. 15

607. Phlox Decussata, hardy pcrennial varieties, from very choice English, German and French collections, mixed..... 10

Drummondii, charming annuals of vivid, beautiful colors, as desirablc as the verbena for their duration of bloom.

608. alba, II. H. A., white............... 10 609. - oculata, white, purple eye....... 10 610. Leopoldi, rosy purple, white eye..... 10 61\%. Empress Eugenie, rose marbled..... 10 614. T1ack Wa rior, purplc crimson.... 10 615. Isabellina, pale yellow........... 10 616. Feynholdii Cardinallis, beautiful deep scarlet....................... 15

1060. — Perfection, very dwarf compact plant, covered with beautiful coppery scarlet flowers..................... 15

1004. Crandiflora, mixed, a very fine mixture of the large flowering varieties, far superior to the old kinds........... 15

617. fine mixed, various colors........... 5

618. choice mixed, extra............. 10 


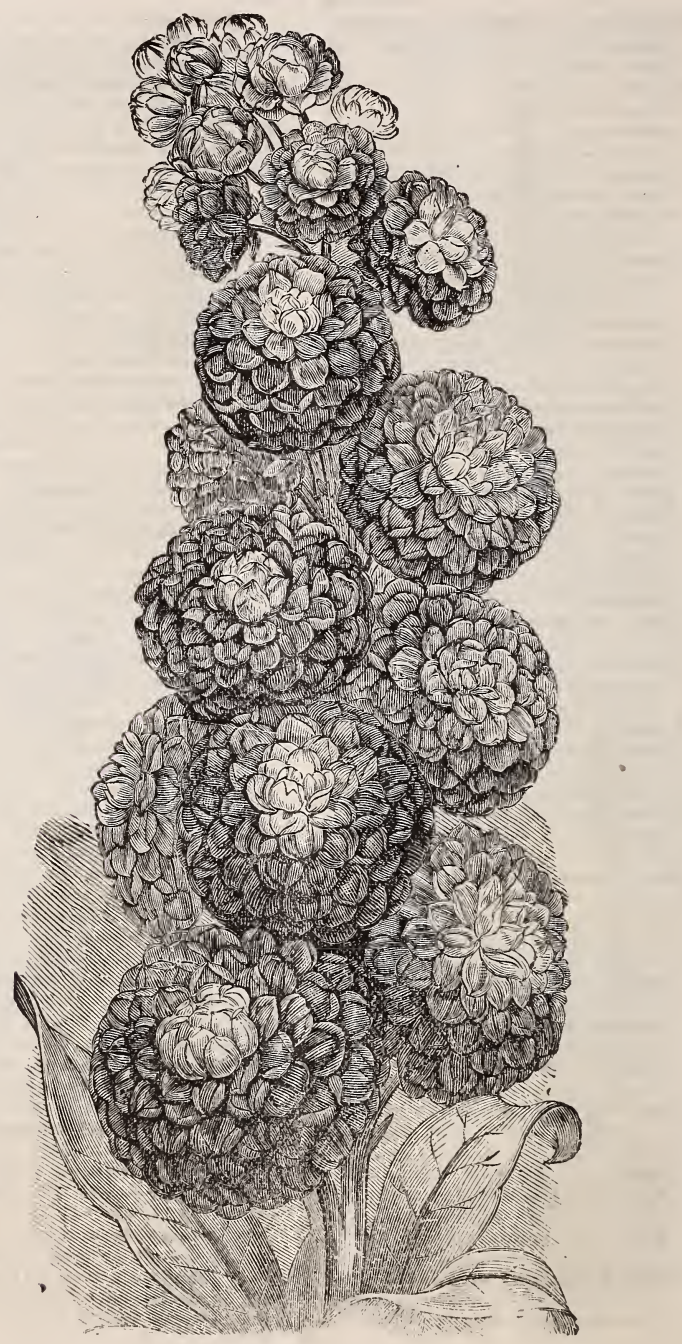

STOCK. No, 725 。 
Na. Price per Pkt.

Picotee Pink, is greatly prized for the beauty and fragrance of its elegantly fringed flowers.

619. — Italian, finest mixed, H. H. P...2 20 620. - good mixed.................. 10

621. Pink, Paisley or Florist, H. H. P., beautifully laced and fragrant flowers, from choice double varieties.............. 20

627. Polycolymna Stuartii, H. H. A., handsome white and yellow everlastings, for winter bouquets...................

Poppy, exceedingly showy, double, com. pact growing plant; effectire in masses or clumps, does not bear transplanting.

628. Carnation, H. A., double mixed, 2 feet

630. Tanumculus, (African Rose), double choice mixed, 1 foot.................. 5

631. Peony-fiowerea, double mixed, 2 feet 5

Portulaca, unsurpassed in the rieh brilliancy of their colors; in an open gravelly situation in the full blaze of the $s \mathrm{nn}$, are very dazzling.

632. white st riped, H. H. A., $1 / 2$ foot......

633. Caryophylloides, rose striped crim. son, $1 / 2$ foot....................... 5

1060. aurea, golden................... 5

634. splendens, rich crimson, $1 / 2$ foot..... 5

635. Thorburni, deep orange, $1 / 2$ foot..... 5

637. Thellusomii alba, beautiful white, $1 / 2$

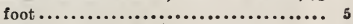

1061. rosea............................ 5

638. extra, choice mixed colors, (see cut).... 5

639. - double, mixed colors, transplant from seed bed, (see cut)............. 10

Primula, (Chinese Primrose), a beautiful winter and early spring flowering green. house plant, sow the seed anytime from January to July, in a light soil.

642. winensis fimbriata, extra choice mixed, from prize flowers.. ......... 50

643. $-\longrightarrow$ good mixed............... 25

1062. —_ flicifolia, Fern-leaved, mixed 50

654. Japonica, H. P., mixed, splendid, sown on a cool border, or in pans; the seed is very slow to germinate, remaining dormant frequently a year............ 20

Py rethrum, desirable free-flowering ornamental plants, with fine double flowers.

656. parthenifolium aureum, (Golden Feather), H. P., beautiful golden foliage

1063. שolden gem, golden foliage, double white flowers...................... s

657. parthenifolla, fl. pl., (double white feverfew), 2 fect.................. 10

658. hyb rids, finest mixed............... 20

Fhodanthe, a delicate and charming plant for the garden and for winter bouquets, start seed under glass.

1057. — fine mixed, single varieties...... 10

Hocket, a fragrant free-flowering, hardy perennial.

1065. mixed, purple and white.............
No.

Ticinus, (Castor Oil Bean), stately and effective plants for garden decoration, of earliest culture and rapid growth.

666. borboniensis arboreus, II. H. A. large leaves, beautifal, 15 fect........ 5

668. Communis, (Palma Christi), castor oil plant, 6 feet, per oz. 10 eents........... 5

1064. gibsoni, new, very fine, dark purple stem and leares... ...................... 5

672. vanguineus, whole plant dark red, 7 feet (see cut) $\ldots \ldots \ldots \ldots \ldots \ldots \ldots \ldots \ldots \ldots \ldots, 5$

673. tricolor, brown, red and green, 7 feet.. 5

Salpiglossis, beautiful annuals, with rich colored delicate and mottled blossoms, plant in a light soil.

687. mixed, H.H.H., from choice plants, (see

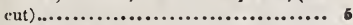

688. — Iwa rf, finest eolors.............

Salvia, all the varieties of this genus are ornamental for the greenhouse and sum. mer garden.

690. coccinea, H. H. P., scarlet, free bloomer, 2 feet........................... 5

692. plendens, (Scarlet Sage), rich scarlet, 3 f.et............................ 10

694. patens, the purest blue flower in cultivation, $2 \frac{1}{2}$ feet..................... 20

695. Sanvitalia procumbens flore. pleno, H. A., a valuable dwarf bed. ding-plant, profuse bloomer, brown and yellow flowers......................

saponaria, charming little plants, flow. ering all the season.

1066. choice mixed, annual varieties....... 5

699. ocy moides, H. P., rosy pnrple, $1 / 4$ foot. 5

Acabiosa or Mourning Bridẹ, handsome summer border plants, with profusions of double flowers in variety.

700, atropurpurea major, mixed colors, 2 fret. (Sce Cut.) H.H.P.......... 5

702. nana, fl. pl., dwarf, double finest mixed 5 Schizanthus, an attractive free-flowering class of plants, with rich and various colored flowers, fine for greenhouses or outdoor culture.

708. mixed, II. II. A., all best colors ........ 5 709. Nensitive Plants, (mimosa pudica), H. H. A., very eurious and interesting plunts, the leaves elosing if touched, pinkish white flowcrs............... 5

smilax, (Myrsiphyllum asparagoides), a beautiful tender climber, much ased by florists for decorative purposes, with beaut'íul delicately orange-scented flowers, per oz. $\$ 2.50 . \ldots \ldots \ldots \ldots \ldots \ldots \ldots . \ldots$

itatice, free flowering, for the garden, raluable for winter bouquets.

721. - Bomduelli, II. II. P., deep golden ycllow.......................... 5

1073. - Incama logbrida, HI.P., fine mixed 10 740. Sweet Clover, (Trifolium Sauveolens) H. B., white flowers, very sweet scented 5 


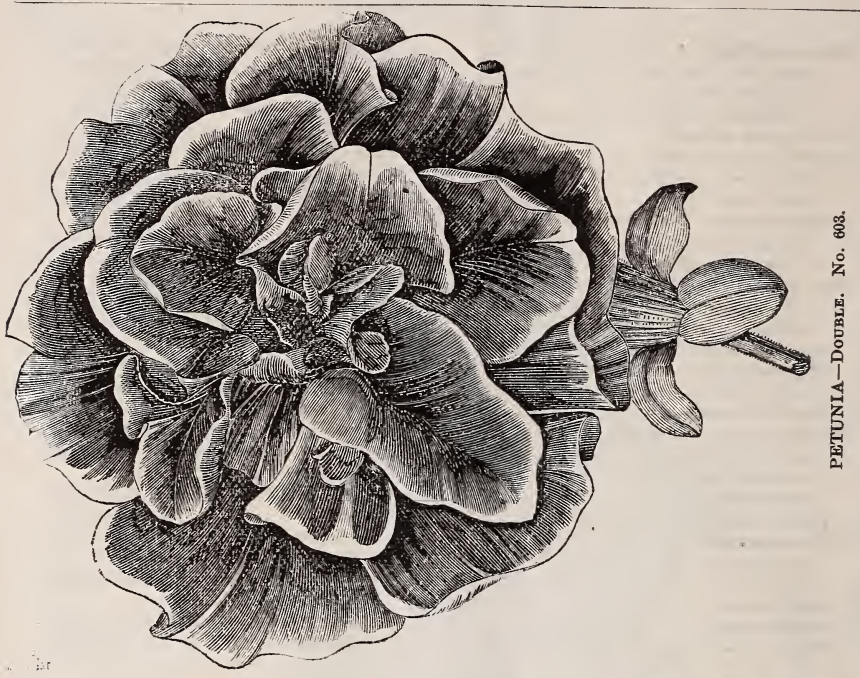

今ं
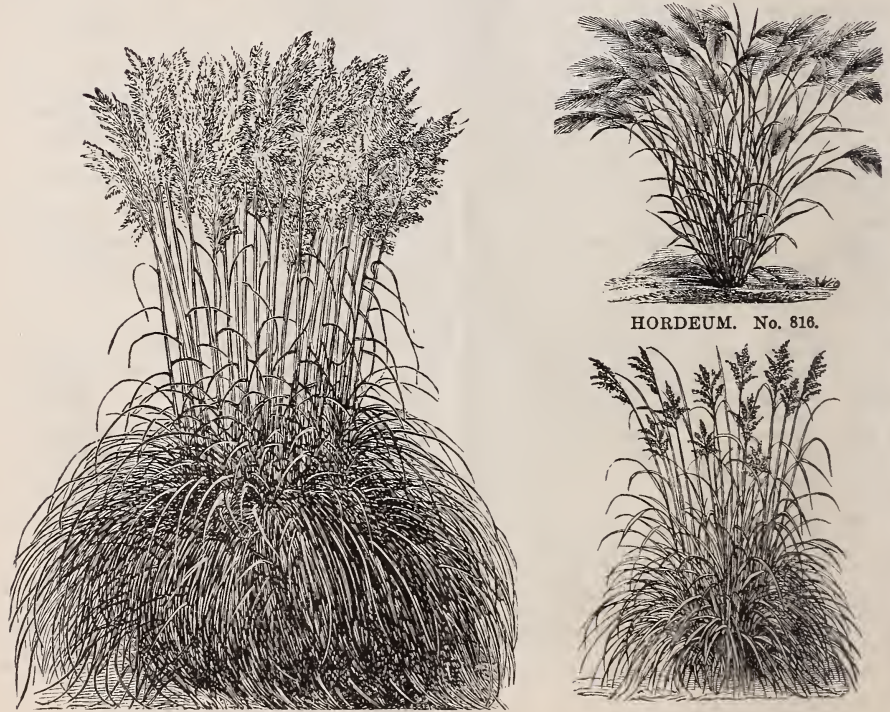

HORDEUM. No. 816.

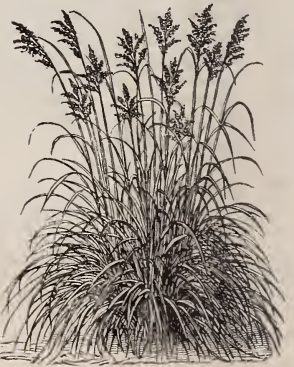

PAMPAS GRASS. No. 851 .

ERIANTHUS. No. 814. 
No.

Price per Pkt.

Stock, (Gillyflower), an old and popular garden favorite, the ten week varicties are the most generally cultivated, blooming in ten or twelve weeks after being sown. Start uader glass and plant out when the plants are quite small.

725. Germun, H. H. A., large flowering, 10 weeks, fine inixed ................... 10

1007. _-blue celeste, sky-blue, splendid, 10 wceks........................ 15

726.

- royal gem, rich, dark carmine, 10 weeks........................... 15

727. - Iwarf walltower leaved, mixed............................ 10

728. -ten week, scarlet or crimson...... 10

729. —- white .................... 10

730. - purple..................... 10

731. — mixed, finc................... 10

1010. new giant perfection, 10 weeks, mixed of pyramidal growth, long spikes of largc beautiful double flowers, $2 \frac{1}{2}$ feet 15

1074. Intermediate, valuable for flowering in late autumn as pot plants, sow in A ugust for spring flowers, mixed....... 10

737. - - Wight Scented, very sweet, (Mathiola Bicornis)...$\ldots \ldots \ldots \ldots \ldots$. 10

375. Sunflower. Sec Helianthus.

Sweet William, (Dianthus Barbatus), a profuse blooming early-flowering gem of easiest culture; seed sown in July will make fine plants by autumn, and with slight protection through the winter will flower the following June.

741. mixed, H. P., very fine, single........ 5

7 42 - scarlet......................

743. - double, extra large flowered, white margintd......................... s

1075. - double pure white fiue.........20

744. Hunt's perfection, very fine, mixed 10 1076. - - pure white.................. 10

1077. - - auricul: flowered.............. 5

1011 Dunnett's Atrosanguineum, blood red, extrit ...................... 10

1012. $\longrightarrow$ fl. pl., double............... 10

750. Tagetes Signata Pumila, a dwarf compact plant, with delicate fern-like foliage, anil bright yellow single flowers, with a reddish brown stripe in the centre

754. Thunbergia, H.H.A., a delicate climber for baskets, vases and grcenhouses, free flowering, sturt in heat, mixed color.....

761. Venus' Tooking Glass, (Campanula Speculum), H. A., free-flowering, reddish violct.........................

Viscaria, profuse flowering plants for beds or borders.

1068. mixed, H. A. .
No.

Price per Pkt.

Verbena, for bedding purposes, arc more easily obtaincd from secd than cuttings, giving healthy plants; sow the seed early under glass and transplant.

762. defiance, H. II. I'., scarlet............. 10

763. coerulea, blue in various shades....... 10

i64. alba, pure white.................. 10

765. Italian, striped.................. 10

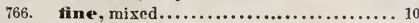

767 . extra choice, mixed............... 20

768. citriodora, (Aloysia), lcmon scented verbena........................ 10

Vinca Thesc beautiful plants arc easily cultivated from seed, flowering in a few months after sowing, admirable for bedding purposes and for the greenhouse.

771. rose, G. S., pretty rose color.......... 10

772. alba, pure white, crimson eye......... 10

Viola, a farorite for its sweet-scented flowers and long continued blooming qualities, will flower first year from seed.

773. odoratia semperflorens, a sweet English violet, II. I'................ 10

774. The Czar, large sweet scented flower 10

Virginia Stock, a very pretty annual for small beds, to cut from; seed can be sown wherc it is to bloom.

1067. mixed, H. A., red and white...........

Wallflower, prized for their delicious fragrance.

785. - Single German, mixed........ 5

786. Dwuble 6 finest mixed.... 10

Whitlavia. These are very effective, thcir rich Gloxinia-like blossoms recommend them for flower beds. Sow the seed where the plants are to remain.

790. grandiflora, H. H. A., deep violet blne, 1 foot....................... 5

791. - alba, pure white, 1 foot...........

792. gloxinoides, violet and white, 1 foot... j

Xeranthemum annum, a showy garden plant, the flowers are valuable for winter bouquets, transplants well.

795 fine mixed, 2 fect................ 5

Zea, ornamental foliage plants of great beauty.

796. japonican variegata, fine striped foliage............................ 10

Zinnia. The flowers are large, beautifully formed and very effective. 4 to 5 fcet.

798. elegans, fl. pl. alba H. H. A., double, pure white..................... 10

799. —_ finest mixed, double, from my prizc varieties.................. 10

800. haageana hybrida, finest double dwarf, deep orange............... 10

Dvidence of Quality, 1880.-My collection of Tropæolums and Nasturtiums was awarled the first prize by the Mass. Horticultural Society, for the best display of this beautiful flower.

"The seeds I bought of you last year gave entire satisfaction, the Jersey Wakefield Cabbage was the best we ever raised. The Mont d'Or Butter Bean takes the lead of all the beans to market. The Trophy Tomato was excellent." February 18, 1880.

B. HOPE. 

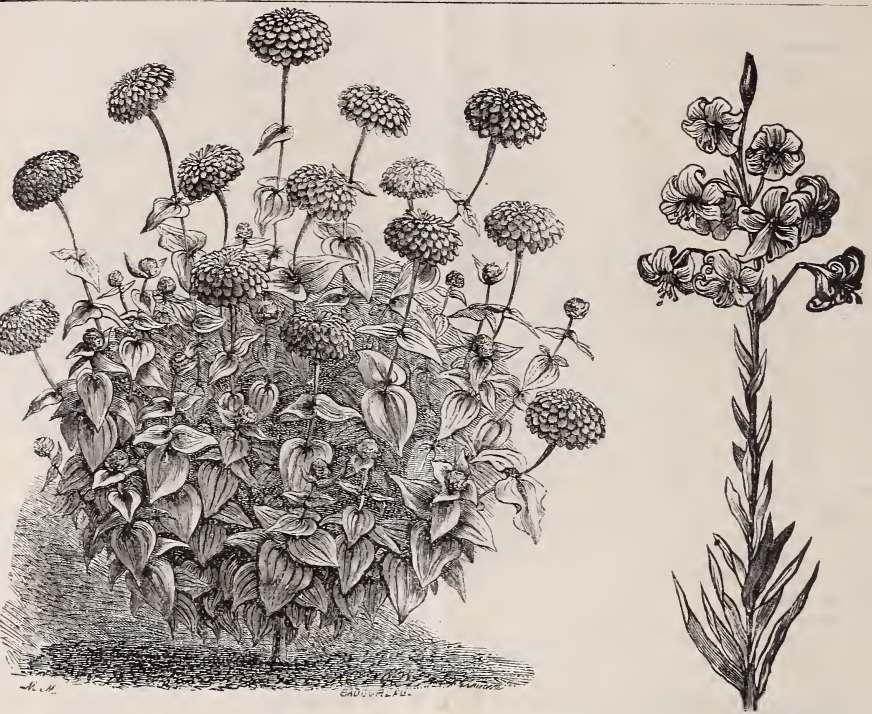

ZINNTA ELEgaNS. Dotble. No. 779.

LILIUM CANDIDUM.

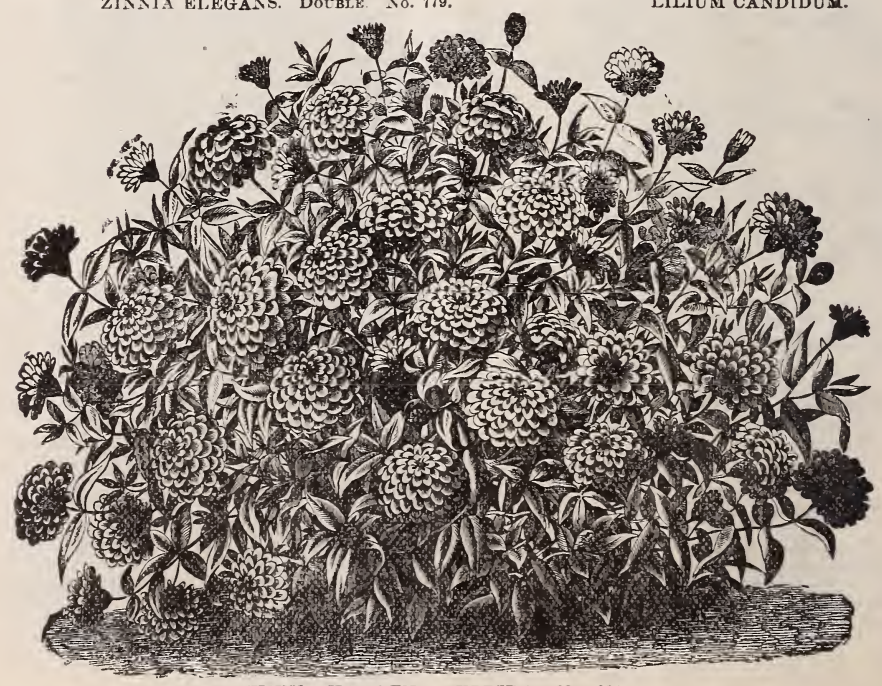




\section{ORNAMENTAL GRASSES.}

A- All the Grasses may be gathered before entirely ripe, and dried for Winter decoration.

No.

802. Agrostis neloulosa, II. A., fine border and bouquet grass, $1 \frac{1}{2}$ feet............ 5

803. pulchella, H. A., very elegant dwarf.. 5 805. Avena sterilis, H. A., Animated Oats.. 5 806. Friza gracilis, H. A., slender Quaking Grass, $1 \frac{1}{2}$ feet..................... 5

807. maxima, (Quaking Grass), H. A., 1 foot, large........................ 5

808. B rom us brizaeformis, H. P., neat border grass, $1 \frac{1}{2}$ feet................ 5

810. Chloris wadiata, $H$. A., radiating, very fine, 2 feet........................ 10

811. Chrysurus anreus, H. A., very pretty, $1 / 2$ foot........................... 5

1019. Eulalia aponica, new hardy ornamental grass, from Japan, forming large clumps, with stems from 6 to 8 feet high, surmounted with gracefully recurved panicles of a light purple color, rivalling the Pampas Grass, with beautifully variegated foliage...................... 20

1079. —— Zebrina, a beautiful variegated grass, from Japan; similar to the above but with markings crossing the leaf horizontally, 3 to 4 feet high.. .......25
No.

812. Coix Iachryma, (Job's Tears), broad corn-like leaves, 2 feet............... 5

813. Eragrostis elegrans, H. A., (Love Grass), very fine, 1 foot............ 5

814. Erianthus 18 avenna, $H$. H P., robust, with plume-like panicles.............. 5

815 Gynerium armenteum, H. H. P. (Pampas Grass).................... 5

1080. Jubatum, new, splendid dark green foliage, beautiful spikes of silvery-red

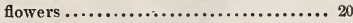

916. Hordeum jubatum, H. A., (Squirrel Tail Grass), 3 feet.................. 5

818. Lagurus ovatus, H. A., (Hare's Tail), 3 feet........................... 5

819. Panicum wulcatum, Н. Н. А., palm formed, 2 fect..................... 10

821. Pennisetum longistylum, H. A., graceful, $1 \frac{1}{2}$ fet.................. 5

823. Stipa pennata, H. P., (Feather Grass), fine, 2 feet....................... 10

1069. elegantissima, a splendid variety for pots or borders................... 10

824. Tricholaena rosea, H. P., exceedingly pretty, 1 foot..................... 10

\section{OBSERVE.}

I desire to call the attention of intending purchasers to my collection of Seeds of Astor, Balsam, Petunia; particularly to the large flowered fringed varieties of the latter, which are very beautiful. Pansies, Phlox Drumondii, Stocks, Verbenas, which are very fine, and to my large and unequalled assortment of Nasturtiums and Tropæolums, both the tall and dwarf varieties; they constitute in themselves a perfect flower garden. The displays of the latter flowers which I made last season before the Mass. Horticultural Society, in Boston, several times, the New England Agricultural Society, at Worcester, and the Rhode Island Society, at Cranston, R. I., were the admiration of all who saw them, and a new developement to most persons; in the wonderful diversity and variety of color, there is perhaps no annual grown to equal them; they adapt themselves to all circumstances, and will grow anywhere, with a wonderful profusion of flowers from July until hard Autumn frost.

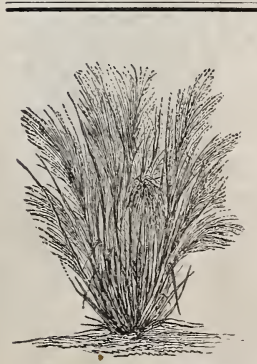

AGROSTIS. No. 802 .

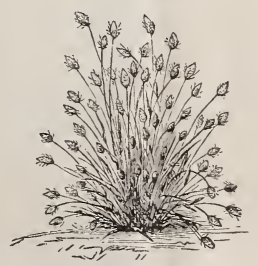

LAGURUS. No. 118.

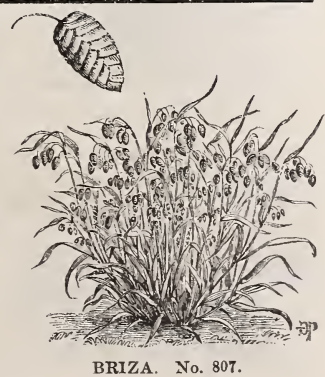

BRIZA. No. 807 . 

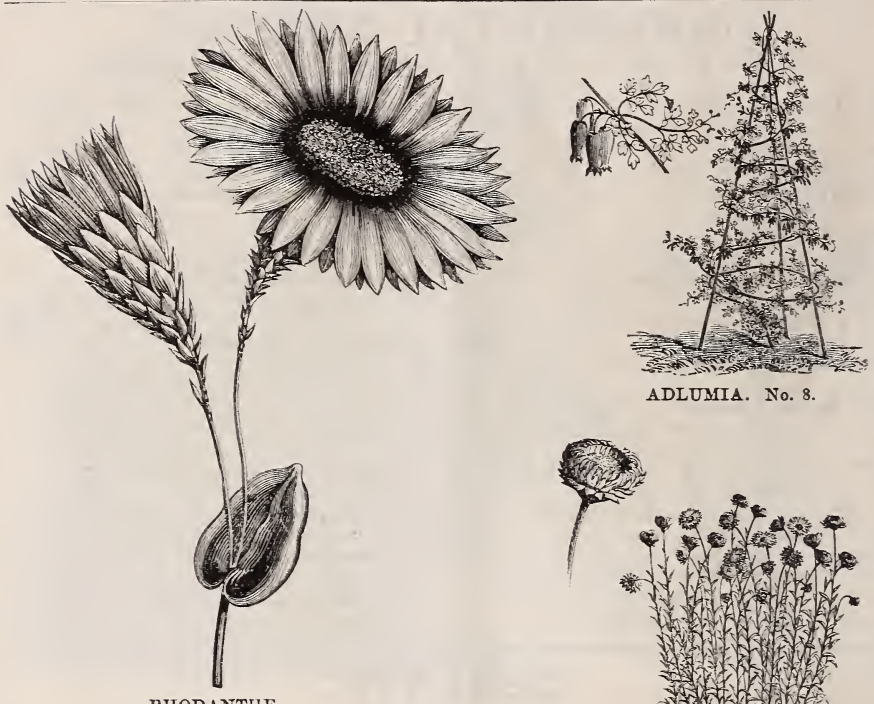

RHODANTHE.

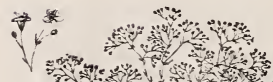
A

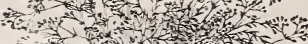
\%के ती

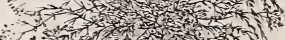

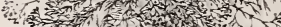
3. के $\rightarrow 2$. If

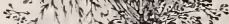

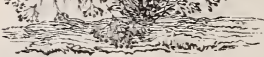
GYPSOPHILA. No. 371.
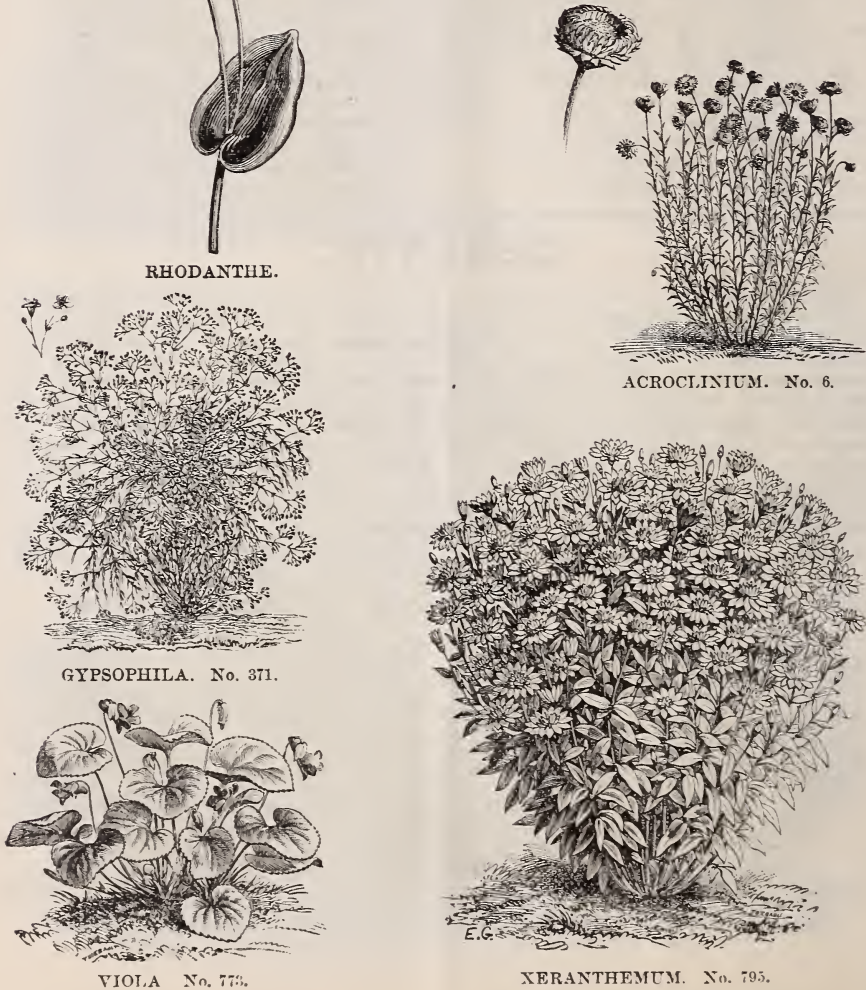

ACROCIINIUM. No. 6. 


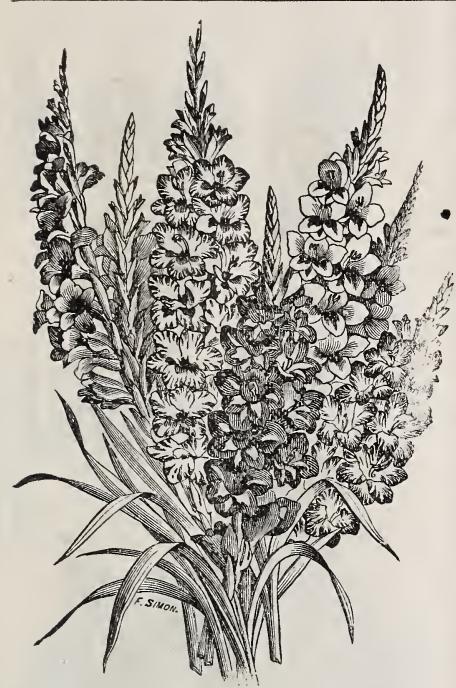

\section{BUILBS AND TUBERS}

\section{GLADIOLUS.}

The Gladiolus of late years, from the success of the French Hybridisers in the great improvement of its flowers, has become the most popular of our Summer flowering bulbs, adapted to the simplest culture.

In growth, robust, erect, with green sword-shaped leaves, and magnificent flower-scape rising from three to five feet in height, in all shades of color, from bright red to almost pure white and yellow, it is suitable for any prominent garden decorative purpose; for a succession of bloom, plantations can be made from April to the last of June.

In the Fall the bulbs should be taken up and carefully dried, and stored for the Winter, where they will be free from frost.

All Bulb orders received during cold weather will be retained until the Bulbs can be sent with safety. If orders are received for seeds at the same time, the latter will be forwarded at once.
960. Abassus, salmon red, flaked scarlet, yellow centre, fine...................\$ 75

911. Achille, currant red, white line in centre 20

1020. A malthee, white, streaked with garnet. 30

899. A ntonius, scarlet cherry, slightly tinged, white centre, per doz. $\$ 1.00 \ldots \ldots \ldots \ldots 10$

1082. Apollon, rosy lilac, rose blotch, fine stripe in the centre.................4 40

1083. Fenvenuto, brilliant light orange-red, white blotch, very fine................ 1.00

899. Brenchleyemsis, vermilion scarlet, very showy for masses, per doz. 50 cents

1021. B rilliant crimson lake............... 20

1022. Celine, rosy white, streaked with rose.. 15

924. Cleopatra, soft lilac, lower division, dark tinged violet, large flowers........

1084. Dianiond, flowers very large, fleshy. white throat, ivory-white streaked car. mine. Splendid. Bronze medal from Mass. Horticultural Society........... 1.50

892. Diama, very tender flesh-colored rose... 20

617. Waith, flesh-colored rose, darker stripes. 15

900. Eldorado, fine pure yellow, striped with red, per doz. $\$ 1.50 \ldots \ldots \ldots \ldots \ldots \ldots \ldots, 15$

925. Etendard, white, slightiy suffused carmine ............................. 30

963. Eva, white tinged rose and lilac, fine.... 75

1023. Goliath, light red, striped and blotched

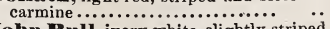

901. John Bull, ivory white, slightly striped sulphur, per doz. 80 cents..............

940. Latous, purple, flaked mauve, white centre, extra......................... 75

1085. Lady Bridport, blush flaked carmine, striped..................... 150

916. Le Poussin, light red, white bloteh... 15

909. Meteor, brilliant dark red, large pure white blotch..................... 40

939. Milton, cherry rose flamed with red, very fine...............................

904. Mme. Arele souchet, white, flamed with crimson rose, large flower........

905. Mme. Basseville, cherry colored, purple stain on white ground, vigorous....

918. Mme. Ae Sevigne, bright cherry, stained pure white.................. 25

937. Mme. Eesakle, pure white, purple rose stains ........................... 15

927. Ime. Periere, white, blotched purple 50

1025. McMl ahon, satin orange-colored, cherry rose, striped rose, fine...............

964. Mr. A. B roomiart, rose ground, tinted orange, tlamed red, white blotch, tine.. 90

965. Parsonii, pink, veined lilac, white

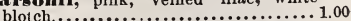

1026. Panorama, lilac, mottled carmine, creamy white throat, white band in cen. tre of each petal, fine................. 1.00

897. Penelope, light pinkish white, stuined 15

943. Primatice, rose, tinted lilac........... 50

967. Frosita, delicate creamy rose, blotched carmine, fine......................... 1.00

908. Reine Victoria, pure white, stained violet carmine, fine, per doz. \$1.00.... 15

945. Shakspeare, white suffused carmine, rose, fine, early.................. 60

932, Sir Wm. Hooker, light cherry, blotched rosy carmine, white ground, fine 40 929. Themis, satin rose, cream-colored blotch 20 1028. Thomas V rethwen, violet, tinged rose 60

898. Van Dyck, amaranth red, striped white 15

922. Velledia, very tender rose, violet stain.. 30

Purchasers selecting twelve varieties from the above list, will be entitled to a discount of ten per cent. from Catalogue prices; twenty-five varietics, a discount of twenty per cent.

The following collections are made up with very fine varieties, although the prices are low; my own selection. A5 $\mathrm{My}$ seedlings are about as good as named kind

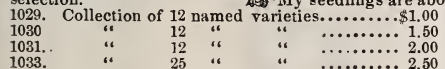

969. 12 choice Hybrids, mixed seedlings.... \$.85 980. 100 " 100 " " " "by express at purchaser's expense............. 4.00 
(2)

IVI)

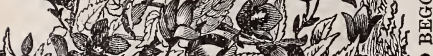

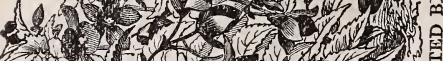

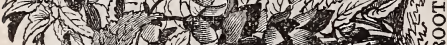

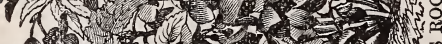

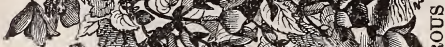
-1) - n

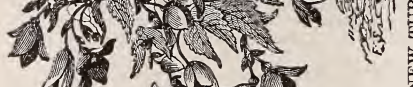
称

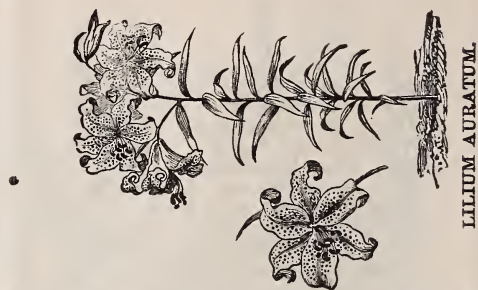

क्षी
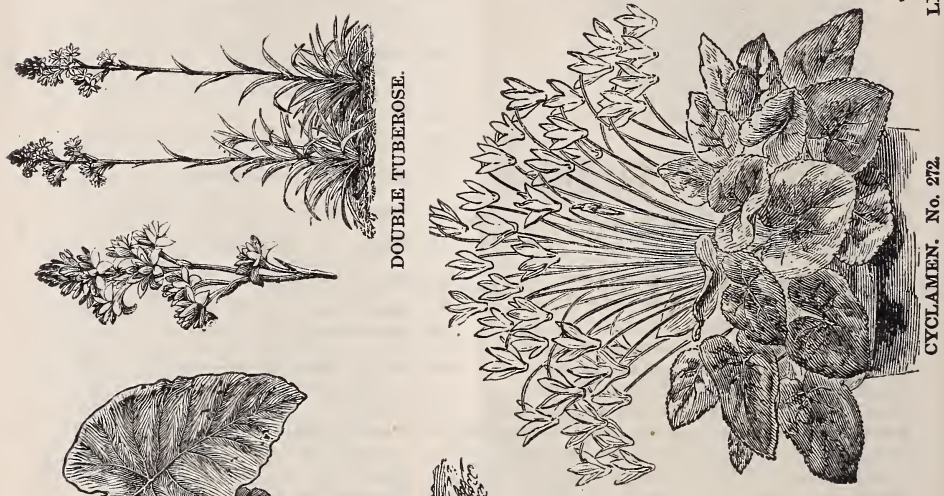

1. क्रें

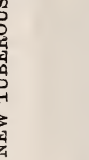


Lillium auratum (Gold Band Lily). They should be planted not less than six inches deep, and with an inch of sand at the base of the bulb, this being most necessary in soil of a tenacious character. Treated in this manner, if the soil is well drained, they have proved perfectly hardy. Fine bulbs of this variety very scarce ; 60 cts., 75 cts., and $\$ 1.00$ each.

Lancifolium rubrum, 20 cents each.

- Roseum, 20 cents each.

Album, 35 cents each.

Monstrosum rubrum, white and crimson, 50 cents each.

Album, pure white, 50 cents each.

Macranthum, 50 cents each.

Punctatum, white, spotted salmon, 40 cents each.

Melpomone, deep crimson, beautiful, 75 cents each.

Candidum, OLD Garden, or Annunciation LiLy.-This valuable old favorite should be planted early in the autumn to enable it to make the usual fall growth, thus it is almost impossible for them to bloom the following season;

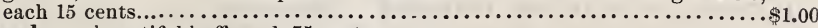

Excelsum, beautiful buff, each 75 cents.

Longiflorum, (Japonicum), one of the best for pot culture. This is perfectly hardy if lifted in September. The check given by this treatment is sufficient to prevent any fall growth, and the bulbs may be planted again just before the ground freezes. Although this is the opposite treatment of that recommended for Candidum, it is just this that renders Longiflorum hardy ; each 10

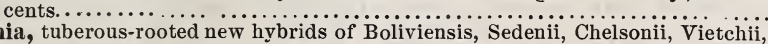

Begonia, tuberous-rooted new hybrids of Boliviensis, Sedenii, Chelsonii, Vietchii,
etc. Good bulbs having already flowered. These splendid varieties, producing branchy and at the same time tufty plants of about twelve to eighteen inches high, are covered during the whole summer and until frost sets in, with bright and elegant flowers; succeeding as well in the shade as in the sun. Each 40 cents.

Calocasia (Caladium) Esculentum, a highly ornamental foliage plant with immense leaves, having a tropical appearance, adapted for the centre of beds, borders or pot culture; 25 to 40 cents each.

Delphinium formosum grandiflorum. Seedling plants in fine colors, various

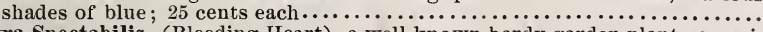

Dielytra Spectabilis, (Bleeding Heart), a well-known hardy garden plant; a capital subject for forcing early for cut flowers in pots for greenhouse and house

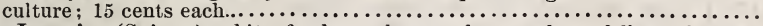

Hoteia Japonica (Spiræa), white, feathery plumes, elegant glossy foliage, for forcing in pots for spring bloom; perfectly hardy ; 20 cents each by express, 25

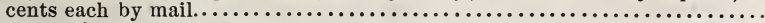

Tritoma uvaria, (Red-Hot Poker Plant), a beautiful class of bulbous plants, flowering in midsummer and until frost, throwing up a tall flower scape three to five feet high, with beautiful racemes of orange-scarlet flower-tubes; 20

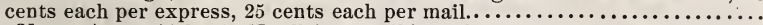

Yucca filamentosa, (Adam's Needle), a striking plant, with a tall flower stem, four to five feet high, crowned with beautiful umbels of waxy-white flowers; strong plants, 50 cents each.

Tuberose. This is pre-eminently a plant for everybody. Its lovely waxy flowers are so fragrant that a few pips will perfume a room, or a single plant a greenhouse; but especially it is of value in furnishing a continuous supply of blooms for bouqets and decorations generally. The pips may be taken off as they expand, and as they do this gradually, a few plants will provide for a long period. When started early in the season (January), a slight bottom heat should be given, as at this time of the year they are slow to start; later they do not require it. Transplant in May or June to the open ground.

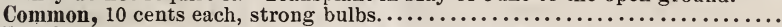

Pearl (new), of dwarf habit and exquisite fragrance, 10 cents each...........

Sweet William, an old popular hardy garden plant, profuse bloomer, various

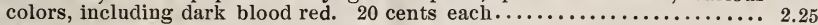

We had Proctorsville, VT. having. The Boston Marrow Squashes were wonders.

Miss L. H. H.
H. The Brour. Mr. Spoonkr. - I can say with truth after using your seeds for six years that they germinate for me
our hot dry climate better than any others I have received. in our hot dry climate better than any others $I$ have received. 


\section{NOOVEITIFS \\ AND \\ Desirable Flower Vegetable Seeds}

OF RECENT INTRODUCTION.

IN ORDERING SAY FROM NOVELTIES.

\section{FLOWER SEEDS.}

CALENDULA OFFICINALIS, "METEOR." New variety of the Marigold, with very large imbricated double striped flowers, bright deep orange on a pale straw color, almost white ground; the stripes very striking; blooming until

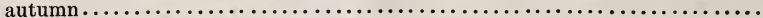

MIGNONETTE, GALLOWAY'S WHITE, a very fine new pure white........... GOLDEN YELLOW, a distinct and fine variety, with large spikes of in-

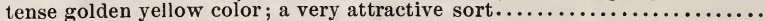

HELIANTHUS ANNUUS NANUS, FOL. VAR., dwarf; nicely variegated-leaved Sunflower; well adapted for ornamental groups.......................

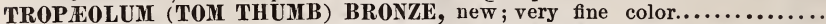
IRIS KEMPEERI, beautiful and interesting plants, with very large flowers,

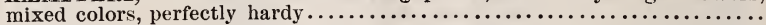

\section{VEGETABLE SEEDS.}

LETTUCE, PAPER WHITE CURLED HEAD, a very tender and very early variety of Lettuce, desirable for forcing or for the open ground............

NEW DWARF OKRA, an improvement on the old Okra; grows about 14 inches

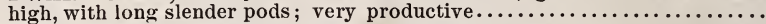

AMERICAN WONDER PEA, unrivalled in productiveness; very early, fine fla-

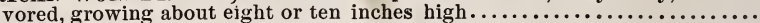

PERFECT GEM SQUASH, this new variety is excellent both as a summer and a winter Squash, vigorous grower and productive; often setting the Squash near the root like the bush varieties, it commences to run and will frequently attain a length of twenty feet; the Squashes are from four to six inches in diameter; flattened; of a creamy white color; ribbed. The fiesh is fine grained, dry and sweet, and is a remarkable keeper. Five packets for $\$ 1.00$

LOW'S NEW PREMIUM TURBAN SQUASH, this new and very fine Squash is a cross between Hubbard and American Turban, having the color, shape and excellence of the Turban, with the dryness and hard shell of the Hubbard. The flavor is rich, fine grained and very sweet; one of the best keepers and very productive. Being earlier than any other running variety, can be planted later in the season, or as a second crop; per oz., 30c., per lb., $\$ 2.50$

NEW SURPRISE MELON, this new Melon has a thin cream-colored skin, thickly netted; the flesh is of a deep salmon color and very thick, of delicious flavor, very early and prolific. All those who have tasted it pronounced it without exception the finest they have eaten. The seed we offer is from selected

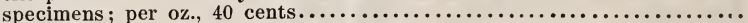

SWEET CORN, EXTRA EARLY TOM THUMB, a very early eight-rowed variety, producing fair sized ears; kernel large, white and sweet; has proved one of the earliest; is very tender, resembling the Crosby or Evergreen in flavor; a viluable sort for market gardeners; per quart, 35 cents, by mail $55 \mathrm{c} . . . .$. .

'TOMATO, LIVINGSTON'S PEREECTION, a new variety of great merit, raised by the originator of the Acme and Paragon varieties, and superior in all respects; shaped like the Acme, but larger, perfectly smooth, blood red in color, bears abundantly until frost, free from seeds; excellent for canning or

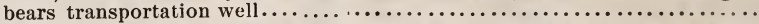




\section{SPOON下耳R’S}

BOSTON MARKET

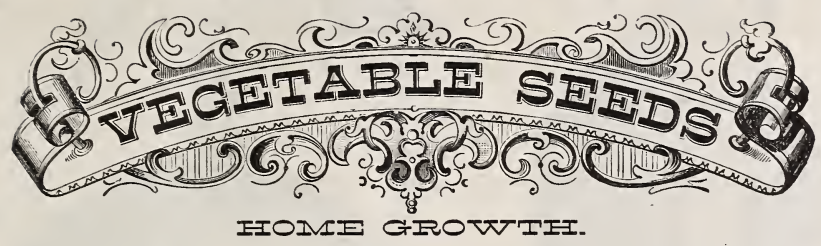

I can confidently recommend my stock as being of the best quality, having been selected with the greatest care and carefully tested.

Some changes have been made in the quotations for vegetable seeds this season. We have fixed the prices the pound at lowest rates at our office, and if ordered sent by mail, 16 cents per pound, or fraction, must be added to cover mail charges. As formerly, seeds by the packet and ounce will be forwarded by mail at catalogue rates, free of extra charge. In all quotations by express, delivery charges to be paid by purchasers.

\section{ARTICH0KE. Cynaria Scolymus.}

Sow the seed in light, rich soil, in April; the following Spring transplant to permanent beds of moist rich loam, two feet apart each way.

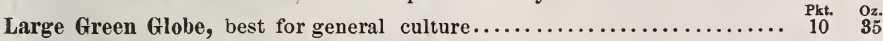

\section{asparaguS. Asparagus Officinalis.}

Sow in drills eighteen inches apart, in April, in a good rich soil; two years old plants should be used in planting, burying the crown just under the surface.

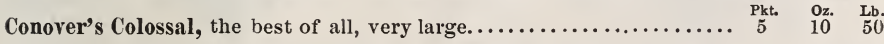

\section{BEANS.-Dwarf, Bush, or Snaps. Phaseolus Vulgaris.}

Do not sow until the weather has become thoroughly settled, and the ground warm; cover the seed lightly. The following varieties of this class will be found to be the best. 15 . cents per pint, 25 cents per quart, extra, when ordered by mail.

Early Long Yellow, six weeks, very productive, used for string or shell beans

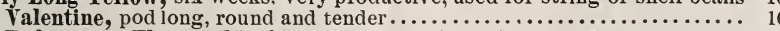

Refugee, or Thousand to One, a very prolific bush bean, not early ...... 10

Mohawk, very hardy, early and prorluctive...................... 10

Large White Kidney, or Royal Dwarf, one of the best late kinds, excellent green, and has no equal for winter use......................... 10

Dwarf Horticultural (true), a half-bush sort, very prolific, excellent green or

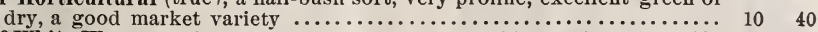

Dwarf White Wax, excellent variety, pods and beans white, early and prolific $10 \quad 30$

Black Wax, pods yellow, superior string bean..................... $10 \quad 30$

Golden Wax, new dwarf; a very superior variety, with yellow transparent pods; valuable as a shell bean................................ $10 \quad 30$

White Marrow, the best for baking, a standard field sort, very prolific...... $10 \quad 20$ 


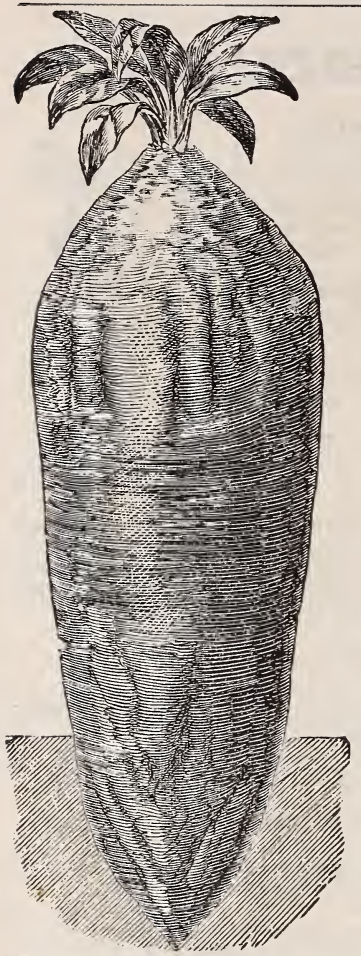

MANGEL WURZEL. Spooner's Improved Mammoth Long Red.

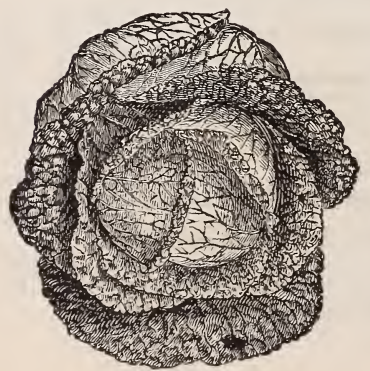

SAVOY. Little Pixie.

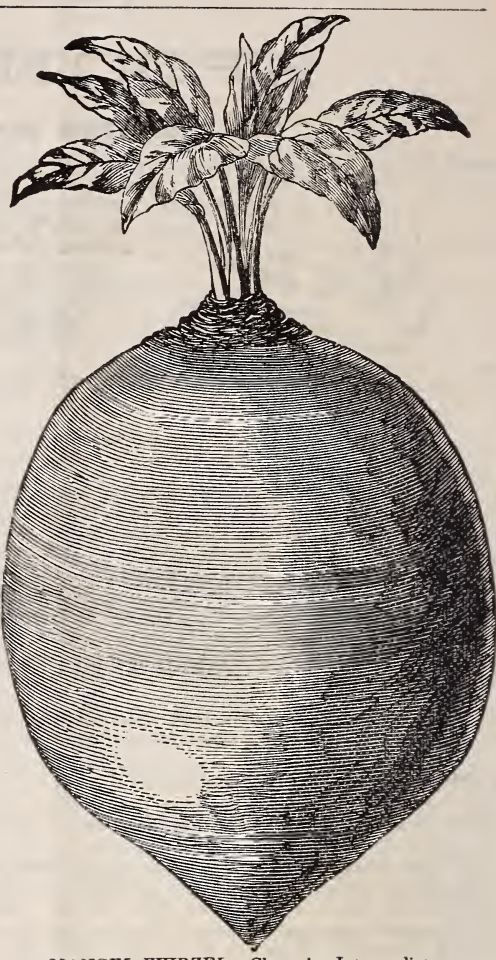

MANGEL WURZEL. Champion Intermediate.

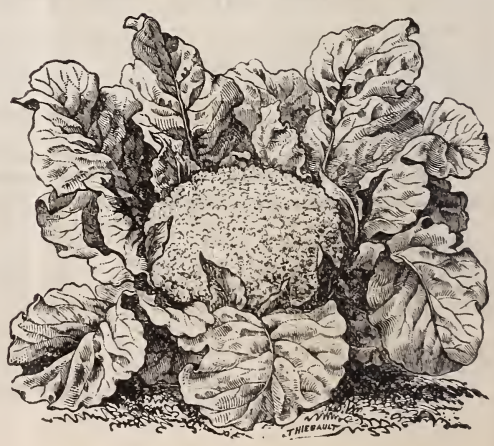

CAULIFLOWER. Lenormand's Short Stem. 


\section{BEANS.-Pole or Running.} Red Cranberry, very productive, a good string or snap bean ................
London Horticultural, or Wren's Egg, productive, pods striped, excellent as

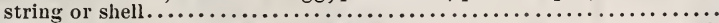

Giant Wax, the best Wax Bean, never stringy, pods very tender, yellowish

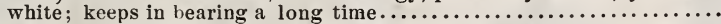
Mont d'or, or Golden Butter, grows about 6 feet high, pods 6 or 8 inches long, thick and very tender, pale lemon color; a delicious bean............

Small Lima, or Sieva, also called Frost Bean, is two weeks earlier than Large

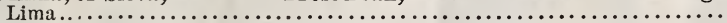

Large Lima, is much esteemed for the table; when planted too early is apt to rot in the ground. Plant in a rich warm soil........................

Lima, Dreer's Improved, an improvement on the old variety, earlier and more

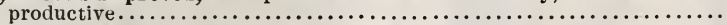

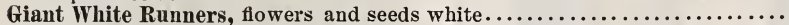
Scarlet Runners, scarlet flowers, very productive, an excellent string bean..

Pkt. Qt.

$10 \quad 35$

$10 \quad 30$

새

$10 \quad 40$

$10 \quad 40$

$10 \quad 40$

$10 \quad 40$

$10 \quad 45$

$10 \quad 50$

$10 \quad 35$

\section{BEET. Beta Vulgaris.}

Sow in April for early, and for a succession till last of June; about the middle of May for general crop. The soil should be a deep rich loam. For the long kinds, trench eighteen inches deep. The rows should be eighteen inches apart, and the plants thinned to eight inches in the rows. Stir the soil often and the plants will make larger roots. As soon as frost occurs. take up roots and store away in dry sand. They will also keep well stored in trenches in the garden or field.

Bastian's Extra Early Blood Turnip, handsome snape, deep red color, superior quality; a profitable market variety ...................

Early Flat Bassano, very early, tender and juicy, will not keep in winter

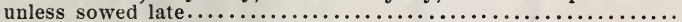

Dark Red Egyptian, earlier than Bassano; turnip shape, small top; excellent for market purposes; one of the very best sorts; ten days

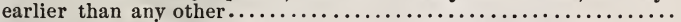

Dewing's Improved Blood Turnip, of fine form and flavor, deep blood red Early Yellow Turnip, very eariy, flesh yellow, very tender............ Long Smooth Dark Blood, good winter variety; color, dark blood red;

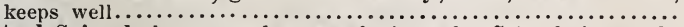
Pkt. Oz. Lb.

Perpetual Spinach, leaves used as a substitute for Spinach, in use the

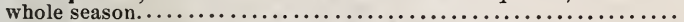

Swiss Chard or Silver, cultivated for its leaf stock, which is served like Asparagus; should be cut often to produce tender shoots..........

Lane's Improved Imperial Sugar, the best variety for feeding to cows or young stock; it contains a greater percentage of sugar than any other variety; is harder and more productive...................

Vilmorin's Improved French White Sugar, is the kind used for sugar

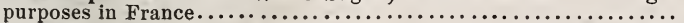

\section{BEE'T. Mavgel Wurzer.}

Sow from middle of April to middle of May; five or six pounds to the acre, manuring heavily. Rows two feet apart; thin out plants to one foot in the rows.

Spooner's Improved Mammoth Long Red, the largest variety in cultivation; largely grown for stock feeding. It stands a good deal out

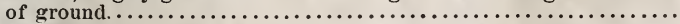

Carter's Warden Orange Globe, the best variety of yellow globe........

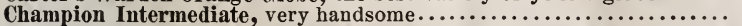

Norbiton Giant Red, a fine English variety; it tends less to a hollow than the Old Long Red......................................... $5{ }^{2} 10 \quad 60$

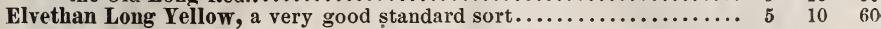

Femit 16 cento per pound or fraction, extra, if ordered by mail. 


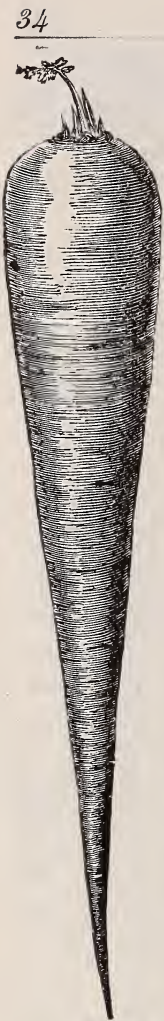

CA.RRO'T, Improved Long Orange.

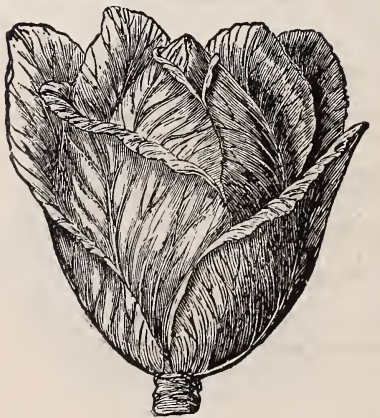

FARLY WINNINGSTADT CABBAGE.
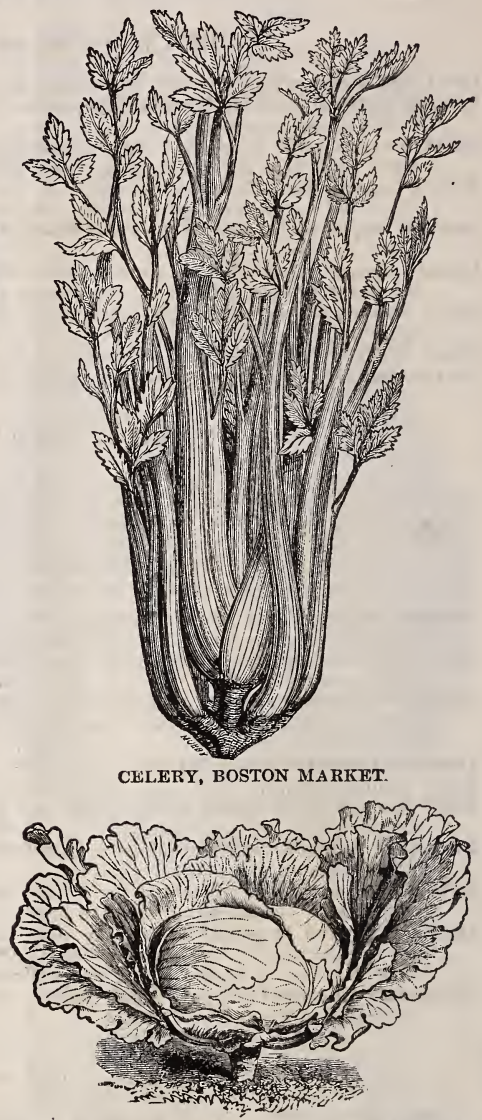

FOTTLER'S IMPROVED BRUNSWICK CABBAGE.

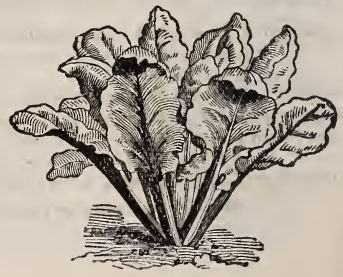

BFET, SWISS-CHARD. 


\section{BORECOLE, or KALE. Brassica Oleracet A'ephala.}

To secure a good crop of this useful winter vegetable requires a deep, rich soil, deep and heavily manured. Sow about the middle of April, covering the seed thinly; cultivate same as cabbages.

Tall Green Curled Scotch, a large and useful variety $\ldots \ldots \ldots \ldots \ldots \ldots . \quad \begin{array}{rlll}\text { Pkt. } & \text { Oz. } & \text { Lb. } & 8\end{array}$

Dwarf Green Curled, or German Greens, very hardy, a standard mar-

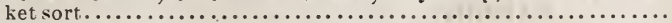

BRUSSELS SPROUTS. Brassica Oleracea Var.

Sow in May, in the same manner as Broccoli, and transplant in July. They become very tender when touched by frost. The numerous small heads, when boiled and dressed with butter, make the most delicious dish of regetables on the table.

Imported, very coinpact, produces in great abundance the whole length of the

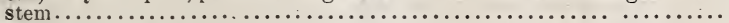

Pkt. Oz.

BR0cCOLI. Brassica Oleracea Botrytis.

Sow early sorts as soon as the ground can be worked in the spring, in shallow drills drawn three or four inches apart. Plant out two feet apart each way, when plants are four inches high. Cultivate same as cabbage; rich soil. Closely allied to the Cauliflower.

Early Purple Cape, a distinct variety of a purple color, excellent flaror, the best for the North........................................... $10 \quad 40$ Carter's Champion, a popular late sort.......................... $10 \quad 40$

\section{CabBage. Brassica Oleracea Capitata.}

Sow the early sorts in autumn, and protect by a cold frame during the winter, transplanting early in spring; or in hot-beds during February and March, and transplant middle of April; or sow the seed in open ground as early in the spring as the ground can be worked. Sow for later crop in April and May. They should be sown in shallow drills four to six inches apart. When the plants are six inches high, transplant into richly manured ground, the early kinds two feet apart; the later kinds, for winter use, three feet apart. The ground must be deeply loosened and worked thoroughly to grow large and good heads. Hoe often to kill weeds, and draw some earth up to the stems. If troubled by the cabbage flea, sprinkle the plant with soot, wool ashes, lime or Scotch snuff.

Cabbage, Henderson's Early Summer, a popular market sort, very early, large and solid; comes in just after the Wakefield.........

Early Schweinfurth, a German variety, the earliest large drumbead,

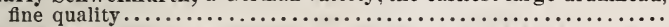

Early Wyman, very popular early market sort, grows to a very

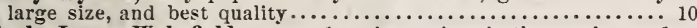

Early Jersey Wakefleld, true. a farorite variety in the markets of

$\begin{array}{rrrr}\text { Boston and New York; is very early, medium size, good quality ... } & 10 & 40 & 5.00 \\ \text { Early York, very early, valuable for spring and summer........... } & 5 & 15 & 1.25\end{array}$

Early Winningstadt, a splendid stock, one of the best in cultivation, comes both early and late, heads cone-shaped, solid and hard; does well in all soils..............................

Large York, larger and somewhat later than Early York; good

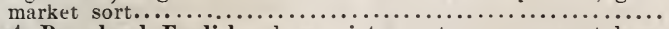

Late Drumhead, English, a large winter sort; very compact, large

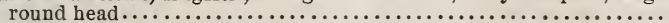

Fottler's Improved Brunswick, undoubtedly the best early Drumhead Pkt. Oz. Lb. variety in the market, often weighing 20 or 30 pounds. The quality is excellent. Comes into use in July and August, and later plantings produce a fine winter cabbage ....................... 10

Stone Mason Drumhead, the standard late cabbage in the Boston market, very large solid head, tender and sweet................. 10

Marblehead Mammoth Drumhead, probably the largest kind of cabbage known, very solid head, sweet and tender, a profitable market

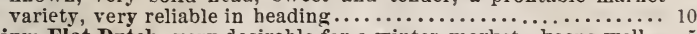

Premium Flat Dutch, very desirable for a winter market; keeps well.. 5

Red Dutch, for pickling ..................................... $10 \quad 20$ 


\section{SAYOY CABBAGE.}

Improved American, very reliable for heading, of superior flavor; much

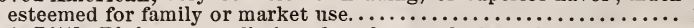

Carter's Little Pixie, a very distinct dwarf sort; the heart is compact and very firm; the best for domestic use....................... $10 \quad 20$

Pkt. Oz. Lb.

\section{CARROTS. Daucus Carota.}

Sow early varieties as soon as the ground can be worked in spring, on a border with warm aspect. The main crop should be sown about the first week in May, in drills about fifteen inches apart. Carrots do the best in sandy loam, well manured.

Early French, Short Horn, very early, small, for table or stock........

Scarlet Horn, one of the earliest; excellent for the table; color deep

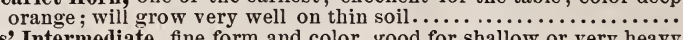

James' Intermediate, fine form and color, good for shallow or very heavy

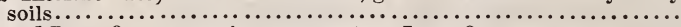

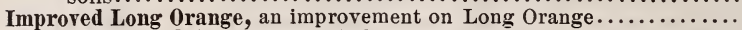

Large White Belgian, largest of all, very productive, good for horses;

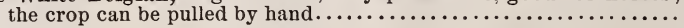

\begin{tabular}{ccr} 
Pkt. & Oz. & Lb. \\
\hline 5 & 20 & 1.50 \\
5 & 15 & 1.00 \\
5 & 15 & 1.00 \\
5 & 10 & 75 \\
5 & 10 & 75
\end{tabular}

\section{CaUliflower. Brassica Oleracea Botrytis Cauliflora.}

Sow from the twentieth of May to the tenth of June, in open ground; transplant when large enough; cultivate same as cabbage, except to manure heavier and hoe oftener. In dry weather the Cauliflower requires abundance of water; hoe deep and draw the soil up to the stem.

Boston Market Improved Early Paris, a very popular American variety, extensively grown for the Boston Market....................

Lenormand's Early Short-stemmed, reliable for general cultivation, fine

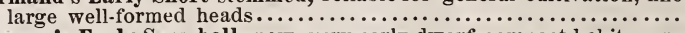

Henderson's Early Snowball, new, very early dwarf compact habit, very

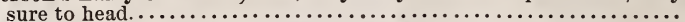

Veitch's Autumn Giant, the heads are magnificent, beautifully white, firm and compact; a valuable late sort. Some beautiful specimens were exhibited before the Mass. Horticultural Society last Autumn......

Walcheren, a popular and valuable variety for early use; produces large white heads; resists the drought of summer better than many sorts

\begin{tabular}{cc} 
Pkt. & Oz. \\
15 & 1.00 \\
10 & 1.00 \\
25 & \\
\hline 10 & 1.00 \\
10 & 60
\end{tabular}

\section{CELERY. Apium Graveolens.}

Sow in hot-bed, or very early in open ground, covering from frost; prick off into beds of the richest soil when the plants are two inches high, and shade them until established. Transplant into rows four or five feet apart, in well-manured trenches a foot in depth, half filled with well-rooted manure; set the plants from ten to twelve inches apart in the rows. In all stages, from sowing the seed till it has nearly finished its growth it requires an abundance of moisture. The seed is rather slow to germinate. Earth up to blanch three or four times during the season, taking care that no earth falls in the centre of the plant.

Boston Market, true (Crosby), the most popular variety in the Boston market; clear white, dwarf, crisp and solid.................... $10 \quad 50$

White Solid, white, crisp and solid, a popular market sort........... 5

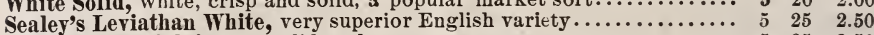

Carter's Dwarf Crimson, solid and compact.................... 5 5 $25 \quad 2.50$

$\begin{array}{llll}\text { Turnip-rooted or Celeriac, forming turnip-shaped bulbs with celery flavor } \quad 5 & 5 & 2.50\end{array}$

Celery Seed, for flavoring soup or pickles......................... $\quad 10 \quad 50$

\section{CHICORY. Cichorium Ixtybes.}

Sow broadcast, or in drills, in June; and, as it advances in growth, continue covering with light soil or old tan. Ready for use in September.

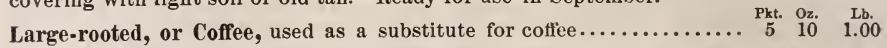




\section{CORN, SWEET. Zea Mays.}

Corn delights in a warm, rich soil. Do not plant until the weather is settled. If planted either in drills or hills, they should be about four feet apart each way. 10 cents per pint, 20 cents per quart, extra, when ordered by mail.

Black Sugar, or Mexican Sweet, sweetest and tenderest of all table varieties Burnham's Sweet, a late variety, ears very large; from twelve to sixteen rows; very productive and of fine flavor......................

Early Minnesota, the earliest variety, very productive, of excellent quality..

Early Narragansett, a very early sort, ears small and fine flavor............

Crosby's Early Twelve-Rowed, a favorite variety in Boston market; very pro-

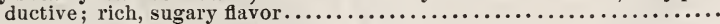

Mammoth Sweet, the largest variety, and late, from twelve to sixteen rowed:

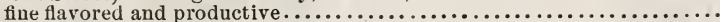

Stowell's Evergreen Sweet, an excellent late sort, very large ears, keeps green

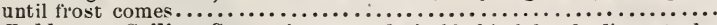

Sweet Fodder, or Soiling Corn, the most desirable kind for feeding stock;

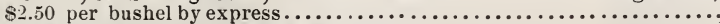

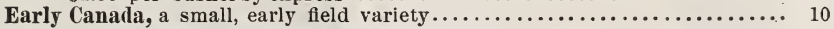

Pkt. Oz.

$10 \quad 20$

$10 \quad 20$

$10 \quad 20$

$10 \quad 20$

$10 \quad 20$

$10 \quad 20$

1020

15

\section{CREsS, or PEPPERGRASS. Lepidium Sativum.}

Sow thickly in shallow drills. That grown in the cool of the season is the best.

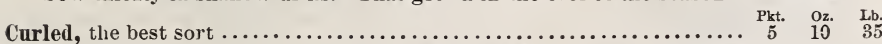

Water, to be planted on the borders of shallow water courses, or in moist

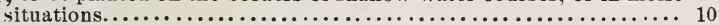

\section{CUCUMBER. Cucumis Satruts.}

When early Cucumbers are desired, sow seed in a hot-bed, or later in a cold frame well covered. When the plants are large enough, place them in previously prepared hills, and protect on cold night with boxes. The seed should not be sown in the open garden until the ground has become warm. Thy should be hoed frequently, and not more than four plants allowed to stand in one hill. Sprinkle the vines with plaster to protect from insects.

Early Russian, earliest in cultivation, about four inches long, in clusters

Green Cluster, bears in clusters, very early and productive..........

Frame, a standard variety for table or pickling, keeps well, early,

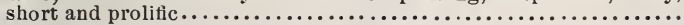

White Spine, a popular sort, good bearer, and a good forcing variety

White Spine Improved, or Boston Uarket, an Improved White Spine, succeeds better than any other for forcing on a large scale with the Boston market gardeners. It is grown extensively South for the

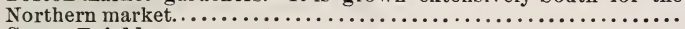

Long Green Prickly, very productive, green and crisp, about 1 foot in

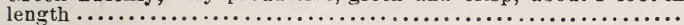

West Indian Gherkin or Burr, a small and desirable sort for pickles, very prolific; the seed is slow to germinate........................ 10

$\begin{array}{ccc}\text { Pkt. } & \text { Oz. } & \text { Lb. } \\ 5 & 10 & \mathbf{7 5} \\ \mathbf{5} & 10 & \mathbf{7 5} \\ & & \\ 5 & 10 & 75 \\ 5 & 10 & \mathbf{7 5}\end{array}$

Tailby's Hybrids, mixed. very beautiful, crisp. tender and fine flavored; excellet for market or table...............................

Boston Pickling, extensively used for pickling in Boston market....... 5

\section{CUCUMBER,-Prize or Frame Varieties.}

From tive to ten seeds each.

Telegraph, (Rollison's) a fine winter sort. abundant cropper, answering in the

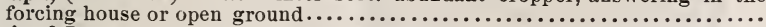

Marquis of Lorne, a new white spined variety, smooth skin, short neck, average

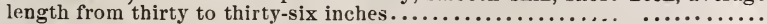

Sooly Qua or Chinese Snake Cucumber, the fruit is of rapid growth, occasionally attaining the length of five feet, and from twelve to sixteen inches in circumference, and is used in a green state just when they attain their full size

General Grant, new, very fine, perfect in form. open ground for forcing......... 


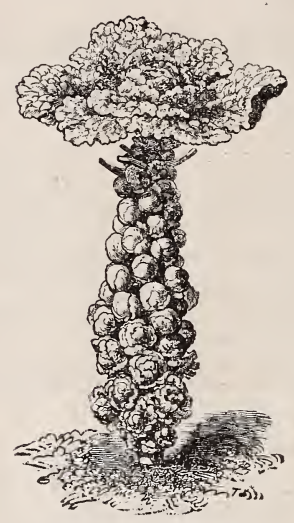

BRUSSELS SPROUTS.

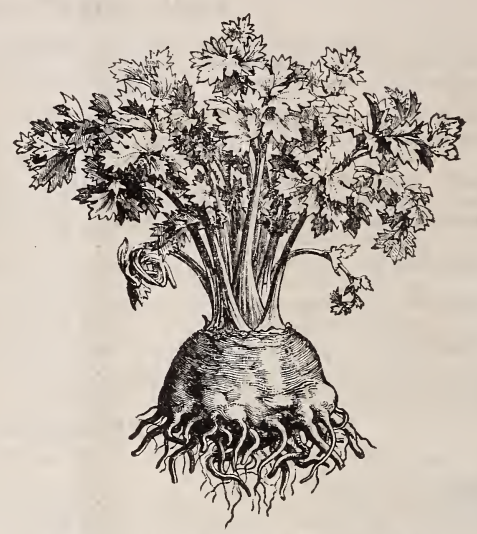

CELERIAC; OR TURNIP-ROOTED CELERY.

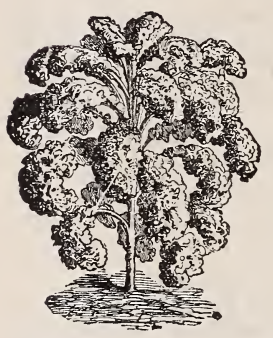

CURLED TALL SCOTCH BORFCOLE.
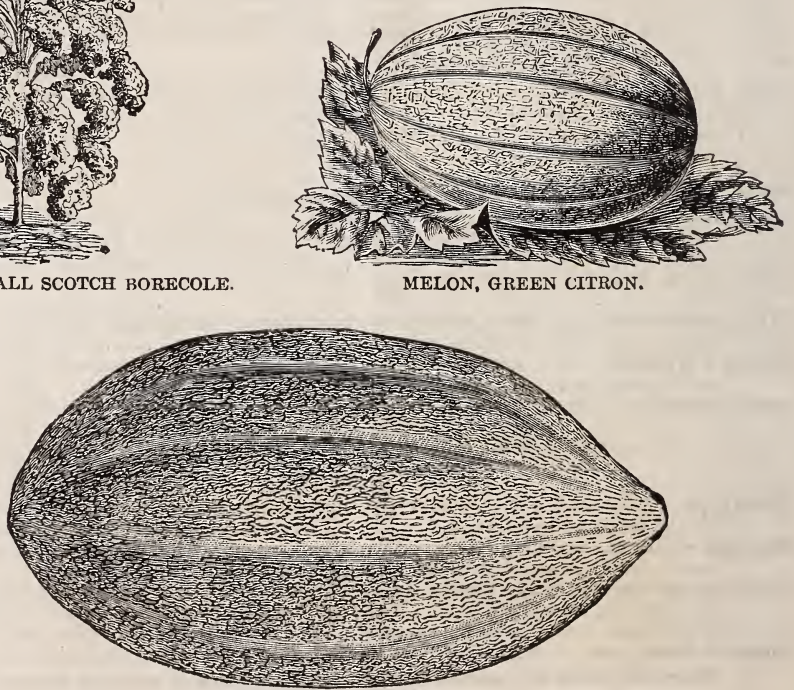

MELON, CASSABA. 


\section{CORN SAlad, Fetticus, or Lambs' Lettuce. Valerlanelda Oltroria.}

Hardy useful salad, is used through autumn, winter and spring. Sow from August till cold weather.

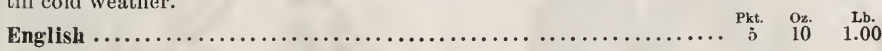

\section{DANDELION. Leontodon Tharaxacum.}

Sow the seed in May, in drills ten inches apart, covering the seed one-half inch deep. The following spring the plants will be fit for use.

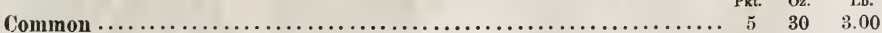

Improved, large leaved, double the size of the Common............ $15 \quad 70$

\section{EGg PLANT. Solanum Ovigerum.}

Sow in a hot-bed; and, when three or four inches high, and the weather has become warm, transplant to good, rich soil, thirty inches apart each way in a sheltered part of the garden.

Early Long Purple, early and productive, good sort for a northern climate... $\begin{gathered}\text { Pkt. } \\ 5\end{gathered} 2_{25}$

New York Improved Purple, a superior market sort, deep color, large size.... $10 \quad 50$

Black Pekin, a new variety, round, purple, very large.................. $10 \quad 60$

\section{ENIDIVE. Chicorium Enivia.}

For early use, sow as soon as the ground can be wor'sed, in drills one foot apart; thin out, when two inches high, to ten inches apart; and when the leaves are eight or nine inches loug, blanch, by gathering the leaves in the hand, and passing a piece of soft string or matting several times round and drawing the top to a point, which will prevent injury from rain penetrating to the centre of the plant. After this, draw a little earth to the plant to support it. The leaves are highly esteemed for salads.

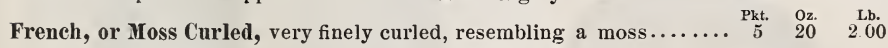

\section{KOHL-RABI, OR TURNIP ROOTED CABBAGE.}

\section{Brassica Caulo Rapa.}

Sow same as Ruta Baga; in earthing up the plant, the bulb must not be covered. Ready for use when it has attained its full size. When fully inatured, are good for stock.

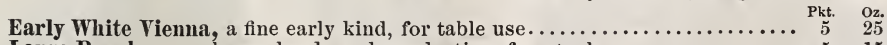

Large Purple, very large, hardy and productive, for stock............ $5 \quad 15$

\section{LETTUCE. LaGtuca Sativa.}

Lettuce succeeds best in a rich and comparatively moist soil; the more rapidly the plants are grown the more tender and brittle will be their quality. Early sorts can be sown in February and March under glass, and later in the open ground, and thinned to 8 or 10 inches in the rows for heading sorts.

All the Year Round, new, a very fine variety for successful sowings....

Early Curled Silesia, very early, tender and sweet, makes a good head,

Early Curled Simpson, this does not head, but forms a close compact

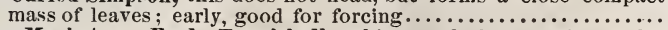

Boston Market, or Early Tennisball, white seed, for growing under glass; very early, heads well formed, hard and crisp............

Tennisball, black seed, tor out-door culture, heads small, fine and

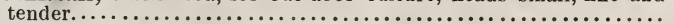

Curled, the finest; forms a compact mass, and rosette of curled leaves 1

Perpignan, a fine German sort, excellent for a hot climate, does not run

to seed as most other varieties ...............................

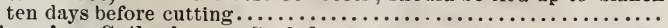

New American Gathering, or Curled ; the leaves are edged with violet, and are exceedingly tender and fine flavored. They are fit for use

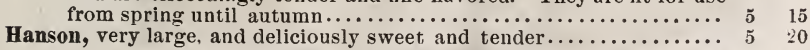

$\begin{array}{rrr}\text { Pkt. } & \text { Oz. } & \text { Lb. } \\ 5 & 25 & 2.50 \\ 5 & 20 & 2.00 \\ 5 & 25 & 2.50 \\ 5 & 25 & 2.50 \\ & & \\ 5 & 25 & 2.50 \\ 10 & 20 & 225 \\ 10 & 25 & 3.00 \\ 5 & 20 & 2.00 \\ & & \\ 5 & 15 & 1.50 \\ 5 & 20 & 2.00\end{array}$

memit 16 cente per pound or fraction, extra, when ordered by mail. 


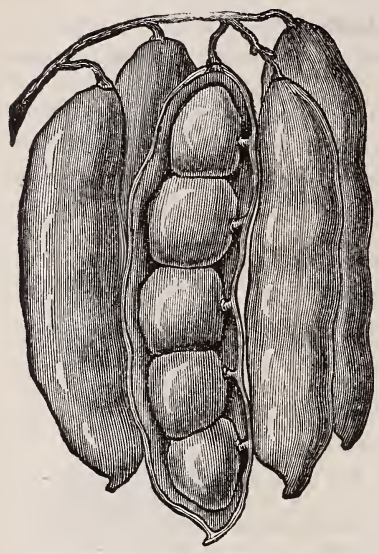

BEANS. Dreer's Improved Lima.
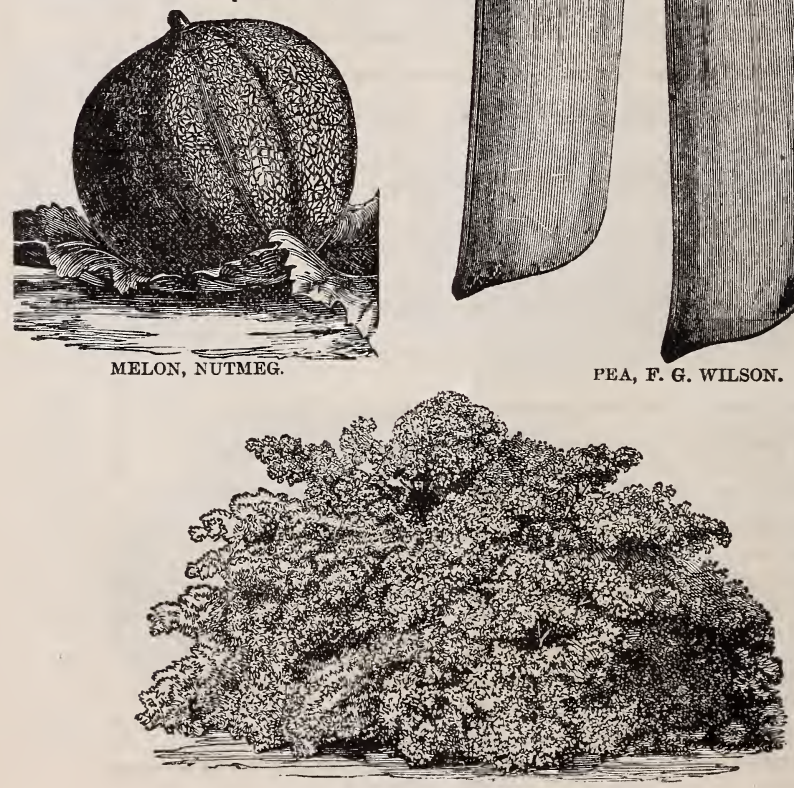

PARSLEY, CHAMPION MOSS CURLED. 


\section{LEEK. Allium Porrum.}

Sow thinly, in very rich soil, as soon as it can be worked, in rows of ten inches apart; when four inches high, thin out to six inches in the rows; if the largest growth is desired, they should be transplanted from the seed bed ten inches apart each way, and well watered.

Broad London Flag, a short plant, with broad leaves, only on two sides...... Pkt. $\quad$ Oz Mussellurg, short stem, very thick, broad leaves, very fine............ 5

\section{maRTyNia. Martinia Proboscidia.}

Sow in open ground in May, one plant to a hill, and three feet apart, each way.

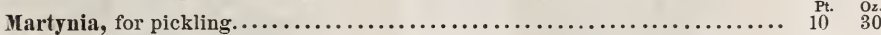

\section{MELON, MUSK VARIETIES. Cuconis Melo.}

Select a warm light soil, and sow ten or twelve seeds when the ground is warm, in hills five or six feet apart, and thin out, when danger from bugs is past, to four plants to a hill. When the vines are a foot long pinch off the end, which will cause the fruit to mature early. The hills must be made rich with thoroughly decomposed manure. Sprinkle the young plants with plaster, or air-slacked lime.

Early Christina, green, with yellow flesh; fine flavor; remarkably early Nutmeg, green flesh, highly scented, very fine...................... Skillman's Fine Yetted, the earliest of the green fleshed melons, excel-

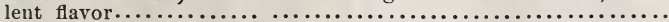

White Japan, from Japan, very early, flesh greenish white, sweet and

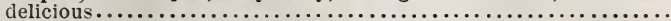

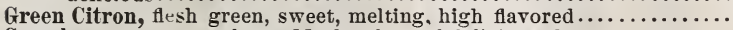

Cassaba, new, a very large Muskmelon, of delicious flavor...........

Large Yellow Cantelope, a good sized melon, salmon-colored flesh, musk

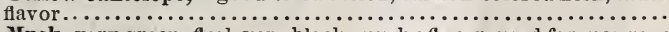

Large Musk, very green, flesh very black, musky flavor, used for mangoes

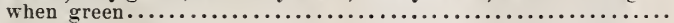

$\begin{array}{ccc}\text { Pkt. } & \text { Oz. } & \text { Lb. } \\ 5 & 10 & 1.00 \\ 5 & 10 & 1.00 \\ 5 & 10 & 1.00 \\ 5 & 10 & 1.00 \\ 5 & 10 & 1.00 \\ 5 & 10 & 1.00 \\ 5 & 15 & 1.00 \\ 5 & 10 & 1.00\end{array}$

\section{Melon, Water. Cucurbita Citrullus.}

Mountain Sweet, one of the best for Northern cultivation, early, very

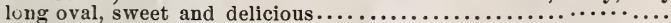

Phinney's Early, fine early market sort, flesh bright red, solid and

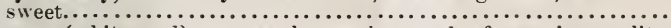

Ice Cream, (white seed), very early, nearly round, of superior quality,

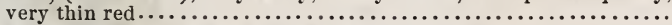

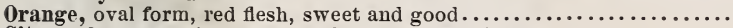
Citron, for preserving, very hardy and productive..................

$\begin{array}{rrr}5 & 10 & 90 \\ 5 & 15 & 1.00 \\ 5 & 10 & 90 \\ 5 & 10 & 1.00 \\ 5 & 10 & 1.00\end{array}$

\section{MUSHR00M. Agaricus Campestris.}

Best Mill-track Mushroom Spawn, per pound, 12c. ; by mail, 25̃c. per pound; eight pounds for $\$ 1.00$, by express, paid by purchaser.

\section{MUSTARD. SINAPIS VAR.}

Sow in shallow drills, six inches apart, every week or two during the season. Used chiefly for salads.

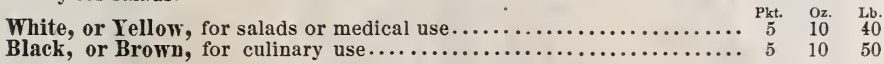

OKRA, or G0MBO. Hibiscus Esculentus.

Sow when the ground has become warm, in hills two and a half feet apart and thin to three plants in a hill.

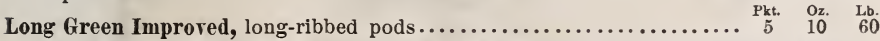

Iemit 16 cents per pound, or fraction, extra, when ordered by mail. 

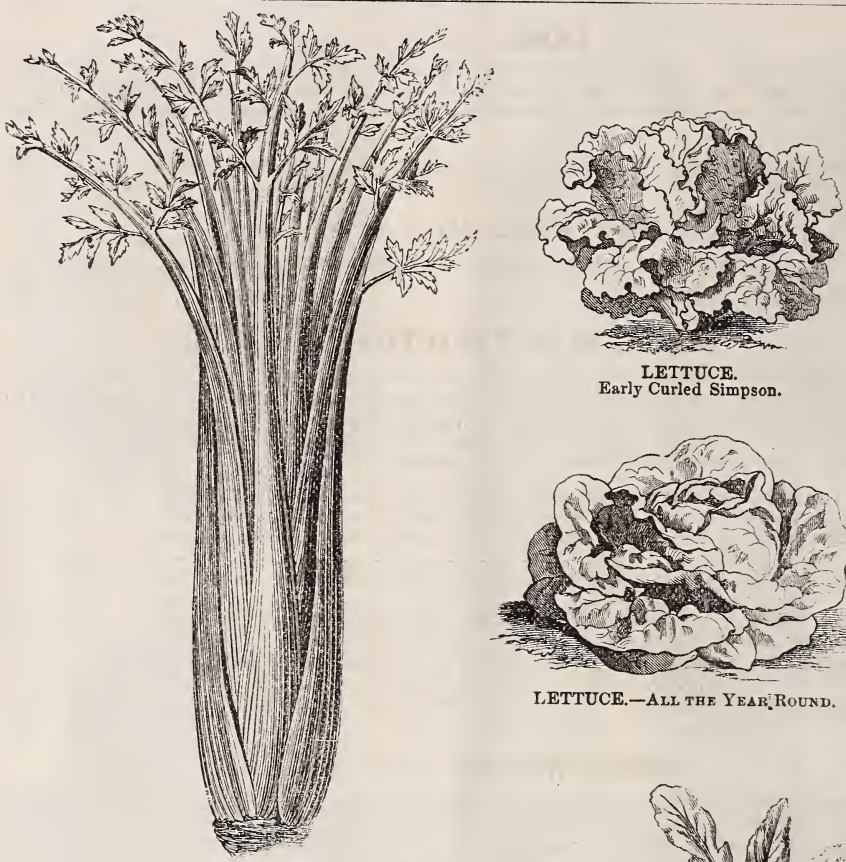

CELERY.-SFaley's Leviataax.

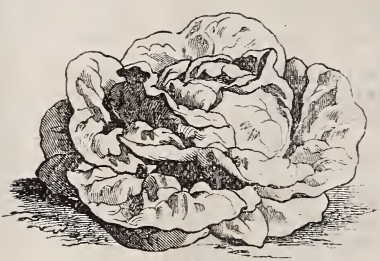

LETTUCE,-ALL THE YEAR.ROUND.

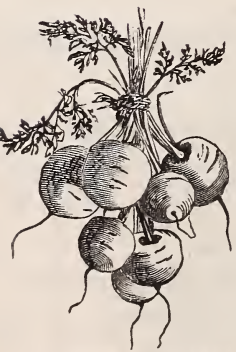

CARROT. FArLY HoRn.

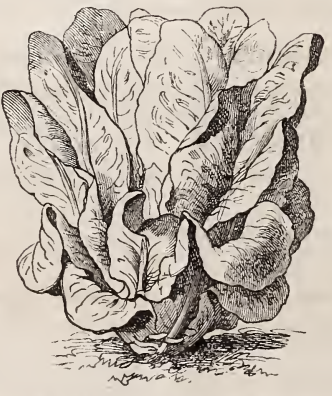

LETTUCE. Paris White Cos.

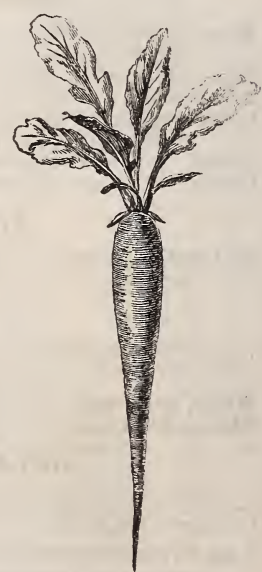

RADISH. I,ONG SCARI.ET 


\section{ONION. Alliem Ceps.}

A rather strong, deep, rich, loamy soil is best suited to this crop. Apply from ten to twelve cords of well decomposed compost to the acre, and plow in shallow and thoroughly cultivate; it will be an advantage to cross-plow and cultivate again, or rake in sections after the second ploughing. Sow the seed thinly, in rows about twelve inches apart. Keep the ground thoroughly clean from weeds. They succeed equally well on the same ground a number of years in succession.

Early Red, very early, productive, a good keeper..... Pkt. Oz. Lb.

Large Red Wethersfield, large size, pleasant flavored, a profitable sort,

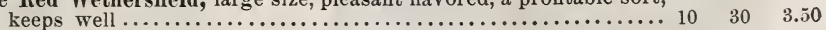

Danver's Yellow, very early and productive, keeps well, a popular market sort.......................................... $40 \quad 40$

\section{NEW ITALIAN ONIONS.}

Giant White Tripoli, immensely large white skin.............. $10 \quad 30 \quad 3.00$

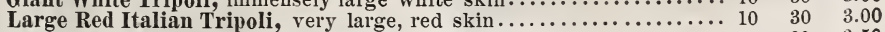
New Giant Rocca of Naples, very large, delicate flavor, globular form... $10 \begin{array}{llll}10 & 30 & 3.50\end{array}$ New Queen, if sown early, will produce onions one or two inches in diameter, early in summer; will keep sound a year; excellent. mild flavored; good for pickles.................................... 10

\section{PARSLey. Petroselinda Sattrum.}

Sow early in spring, in rich soil, drills one foot apart; thin out to four inches apart. The seed germinates verr slowly, so that it will be found of great advantage to soak it in warm (not hot) water, several hours before sowing.

Curled, or Double, dwarf and tender, leaves beautifully curled, used for

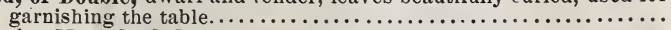
Champion Moss Curled, new, elegant variety for garnishing $\ldots \ldots \ldots \ldots$
Fern-Leaved, most superb form of parsley, being more like crested fern $5 \quad 10 \quad 75$ Fern-Leaved, most superb form of parsley, being more like crested fern
or the most beautiful moss; worthy of being grown as a pot plant

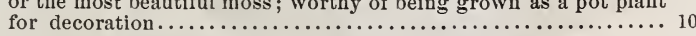

\section{PaRsnip. Pastinaca Satina.}

Sow in deep, rich soil, in drills fifteen inches apart, one inch deep, as soon as the ground is in good working condition. Hoe often. A very nutritious vegetable. The parsnip is excellent for cows and pigs.

Abbott's Improved Hollow Crown, largest and best for general use.... $\quad 5 \quad \begin{array}{llll}5 & 50\end{array}$

New Maltese, an excellent English variety, great improvement in texture

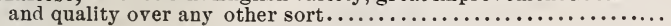

\section{PEPPER. CAPSICUM.}

Sow in hot-bed the first week in April, in drills six inches apart, and transplaut to open ground when the soil has $b=c o m e$ warm, fifteen inches apart each way; at about the same time, they may be sown out of doors, in drills eighteen inches apart, and finally thinned out about twelve inches in the rows. The ground should be made very rich by a liberal supply of manure before planting, or afterwards by an application of guano or other fertilizer.

Chili, conical, about two inches in length, brilliant scarlet when ripe........ Cayenne, pods cone-shaped and red when ripe; best for seasoning pickles.... Cherry, small, smooth and round, dwarf, a great bearer, color scarlet....... 5 Long Red, coral red; 4 inches long; very productive................... Squash, tomato shaped, best sort for pickling; a great favorite, very productive Monstrosum, or Grossum, a new French sort, very large, good for mangoes.. Sweet Spanish, the earliest of all ; sweet, mild and pleasant flavor; used for

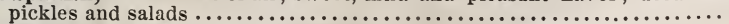

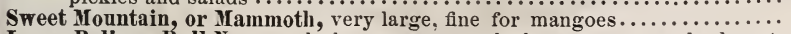

Large Bell, or Bull Nose, pods large, sweet and pleasant; a standard sort,

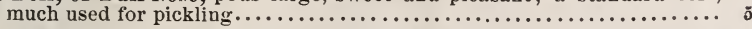

50 30 30 25 30 30 


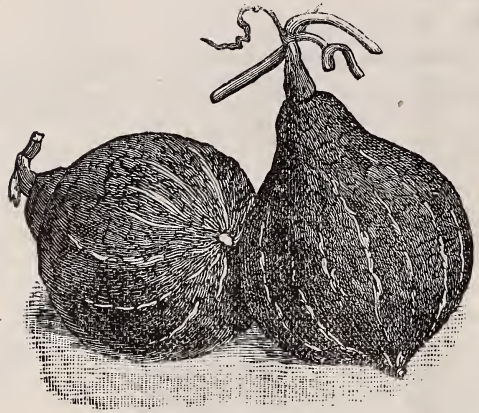

HUBBARD SQUASH.

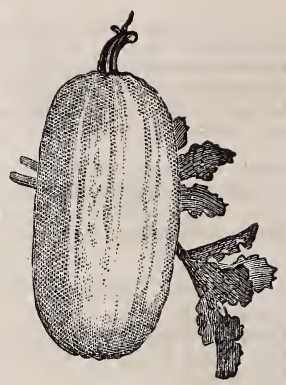

SOUASH.

English Vegetable Marrow.

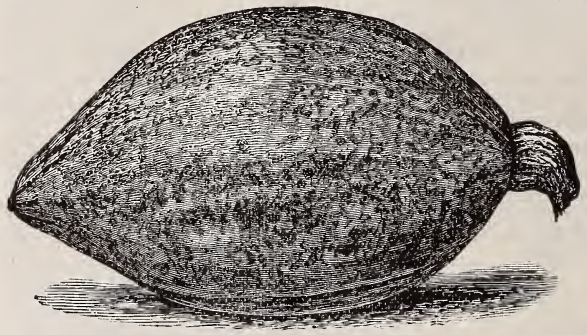

MARBLEHEAD SQUASH.

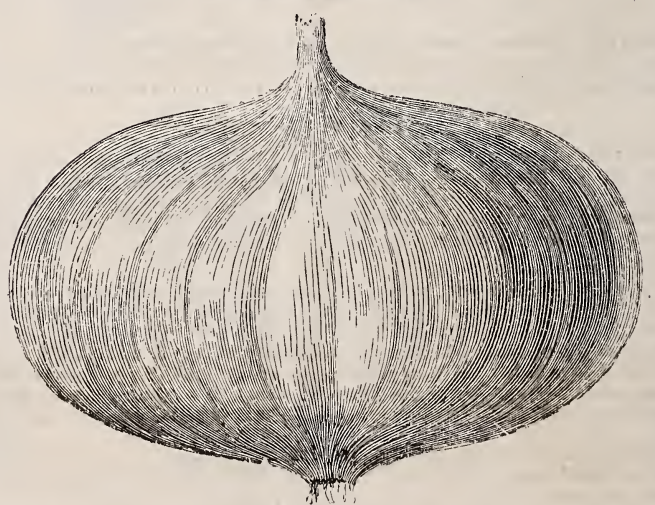

ITALIAN ONION. 


\section{PUMPKin. Cucurbita Pepo.}

Sow in hills, eight feet apart, when the ground has become warn.

Large

Large Cheese, hardy, very productive, reddish orange skin........

Connecticut Field, a large, yellow sort for field culture............ 5 5 $10 \quad 50$

Large Tours, or Mammoth, varying from one hundred to two hundred and fifty pounds....................................... 10

30

\section{PEAS. Pisum Satrum.}

For an early crop, sow as soon as the ground can be worked, in a warm situation, and on soil manured the previous year, in rows three feet apart, and covered three inches deep. Bush the tall growing kinds when about six inches high. 15 cents per pint, 25 per quart extra, when ordered by mail.

Extra Early Premium Gem, a new early dwarf wrinkled pea ; an improvement

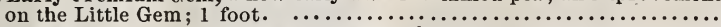

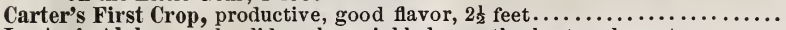
Laxton's Alpha, a splendid early wrinkled pea, the best early sort.......... Early Daniel 0'Ronke, very productive, a good market sort, 3 feet...........

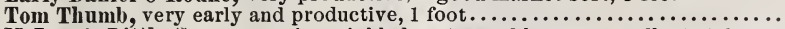
McLean's Little Gem, an early wrinkled sort, good bearer, excellent, 1 foot.. Blue Peter, a delicious dwarf pea, wonderfully productive $\ldots \ldots \ldots \ldots \ldots \ldots$ Advancer (McLean's), a wrinkled pea; two weeks earlier than Champion of England : very prolific; a profitable pea for market; 2 feet........... Champion of England, an old, standard sort, of delicious flavor; one of the

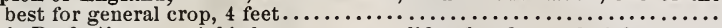
Veitch's Perfection, a wrinkled sort; very prolific ; fine flavored; 3 feet...... G. F. Wilson, an improvement on the preceding; a week earlier; of exquisite

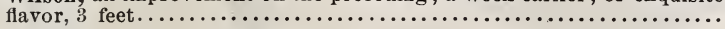

Pkt. Qt.

$10 \quad 45$

1030

$10 \quad 45$

$10 \quad 30$

$10 \quad 35$

$10 \quad 35$

$10 \quad 45$

1030

1025

$10 \quad 50$

$10 \quad 50$

\section{RADISH. Raphanus Sattrus.}

For early use, sow in gentle hot-bed in February, and out of doors as soon as the soil can be worked. Sow in drills eight inches apart, and thin to two inches in the rows. The soil should be very light, rich and mellow; as the roots are more succulent when grown quickly. For a succession, sow every two weeks. The turnip-rooted and oliveshaped are best for summer sowing.

Scarlet Turnip, quick-growing, mild and crisp when young......... Pkt. Oz. Lb.

White Turnip, white flesh color, like Scarlet in shape............... $\mathbf{5}^{5} \quad$\begin{tabular}{lll}
10 & 60 \\
\hline
\end{tabular}

Scarlet Olive-Shaped, very early, quick growth, tender............... 5 . $10 \quad 70$

French Breakfast, a quick-growing sort, of exquisite flavor ; scarlet, oliveshaped, with white tip; one of the best in cultivation..$\ldots \ldots \ldots$.

Early Short Top, long scarlet; the standard market variety; flesh white,

crisp, good flavor......................................... 5 $10 \quad 50$

Wood's Early Frame, excellent sort for forcing; half-long scarlet........ 5 5 $10 \quad 70$

China Winter Rose, skin rose, flesh white, tender................. 5 5 $10 \quad 80$

\section{RHUBARB. Rheum Hybridum.}

Sow in spring, in drills one foot apart. The following spring, transplant to deep, rich soil, four feet apart each way.

Victoria, large and fine for cooking, one of the best $\ldots \ldots \ldots \ldots \ldots \ldots \ldots \ldots \ldots . \quad \begin{gathered}\text { Pkt. } \\ 5\end{gathered}$

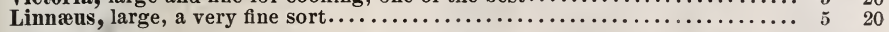

\section{SPINACH. · Spinacia Oleracea.}

Sow the summer variety thinly, in drills fifteen inches apart. The best soil is a strong, deep and rich loam; if very heavy it must be well drained. For the winter, or prickly, a light soil is best; and the beds in which it is sown should be raised a few inches above the surrounding soil. Protect during winter with fir boughs or litter.

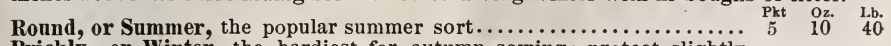
Prickly, or Winter, the hardiest for autumn sowing; protect slightly

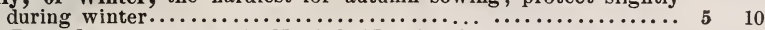

Savoy-Leaved, large, grown in Norfolk, Va., for Northern markets..... ${ }_{5} \quad 10$

Remic 16 cents per pound or fraction, extra, when ordered by mail. 


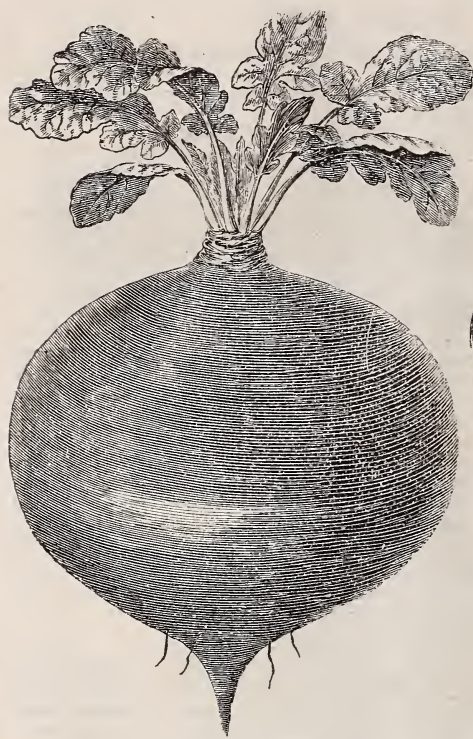

RUTA BAGA. Carter's Imperial Hardy.

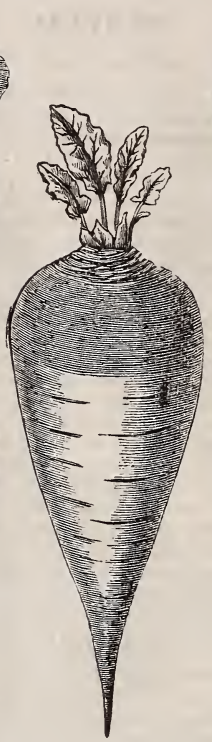

TURNIP. Jersey Navet.

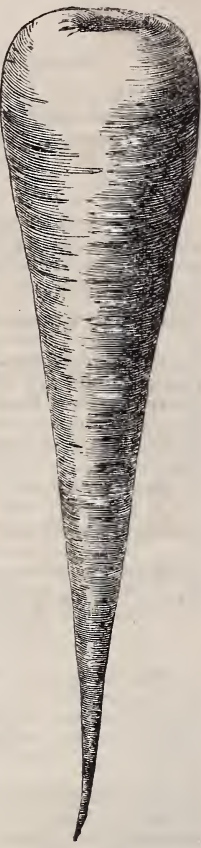

PARSNIP.

Improved Hollow Crown.
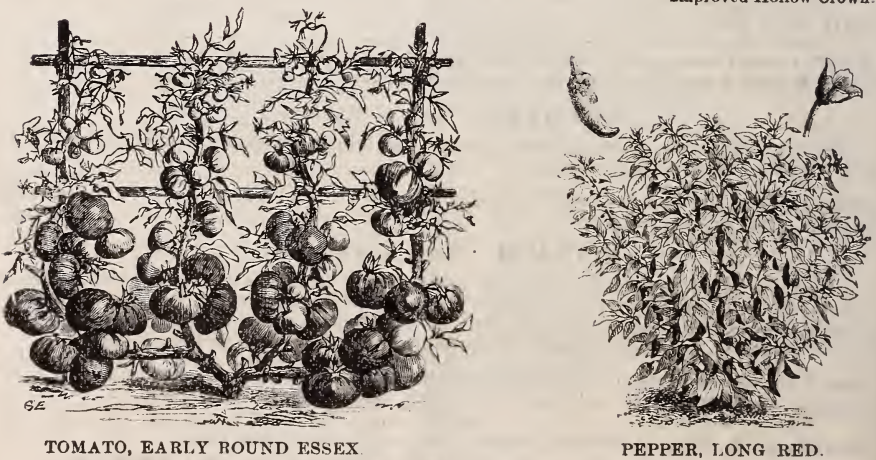

PEPPER, I,ONG RED. 


\section{SALSIFY. Tragopogon Porrirolits.}

Sow in drills one inch deep, fourteen inches apart, and thin the plants to three or four inches in the row. Ready for use in October; can remain in the ground all winter. When cooked, has the flavor of oysters.

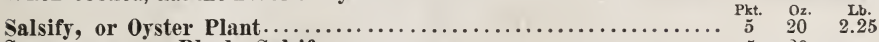

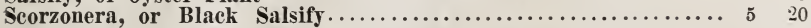

\section{SQUASH. Cucurbita Melo-Pepo.}

These, in common with Cucumber, Melon, and other seeds of the same class, ought not to be sown until the weather has become warm and settled; the hills should be made very rich, and not more than three plants left in each. Keep the vines well covered with plaster when young, to protect from bugs.

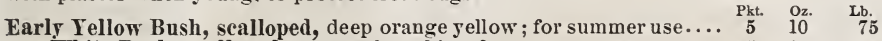

White Bush, scalloped, very early, white, for summer use......... 5 $\begin{aligned} & 5 \\ & 75\end{aligned}$

The above is known as Patty-Pan in the Southern States.

Summer Crookneck, very early and productive; for summer use.. $\quad \begin{array}{llll}5 & 10 & 75\end{array}$

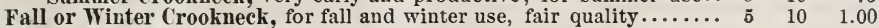

Boston Marrow, the standard Boston market sort; color, rich orange; very productive; keeps well in winter.......................

Hubbard, very dry and sweet; hard shell; will keep longer than any

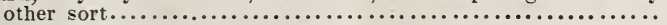

Marblehead, harder shell than the Hubbard, better flavored, and keeps even better than that fine sort.................................

Turban Improved American, or Turk's Cap, the finest and richest flavored of all the Autumn Squashes, but will not keep well in winter

Mammoth, very productive; of immense size - from 100 to 300 pounds ;

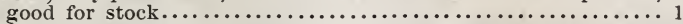

Butman, resembles very much the Hubbard; of a bright green, interspersed with white; remarkably dry, sweet and delicious, keeping

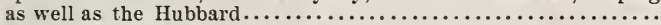

Moore's Vegetable Cream, this is a great acquisition. As a summer variety, it should be used before the hard sbell forms, in the autumn excellent for pies. An English Vegetable Marrow; in

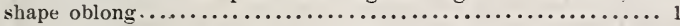

5 $10 \quad 90$

$5 \quad 10 \quad 1.00$

\section{TOMATO. Solandm Lycopersicty.}

Sow in March on hot-bed; and, when two or three inches high, transplant to boxes; shade until established. They may be started in pots or boxes in the window, or, later in the open ground, when the soil has become warm. The richer the soil, the more abundant and handsome will be the fruit. A light soil and warm location will tend to develop an earlier crop.

Acme, early, of unequalled excellence; of uniform size, the best market sort,

round, very solid, pinkish color, very productive, it has no green core... 10
Early Round Essex, very early ; solid and smooth; extremely prolific; one of

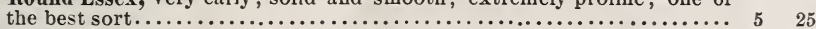

Canada Victor, a new sort from Canada; large, solid and productive......... 5

Trophy, very large, generally smooth and solid; extra selected............ 5 5 40

Generai Grant, a popular market sort; smooth and round, very productive... $\quad 5 \quad 5$

Boston Market, one of the best for market or private use................ $5 \quad 25$

Hathaway's Excelsior, early, smooth, solid, and of best quality; excellent

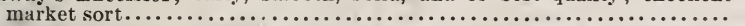

The C'onqueror, claimed to be the earliest sort in cultivation; good size, deep

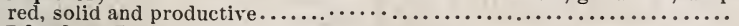

Fejee Island, or Lester's, large size, fine flavor, pinkish red. a good late sort..

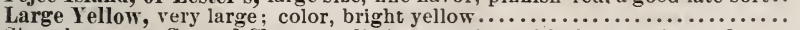

Strawberry, or Ground Cherry, a distinct species, with the strawberry flavor; grows in a husk; will keep in husk all winter; good for preserving..... 10

French Tree, or Tomato de Laye, grows erect, in tree form; very ornamental;

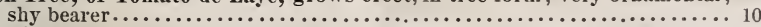

Green Gage, it is very prolific, bearing clusters of fruit, of a beautiful citron

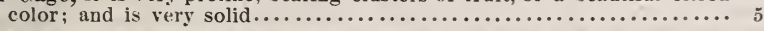

Remit 16 centw per pound or fraction, extra, $u$ ben ordered by mail. 


\section{TOBACCO. Nicotiass.}

Connecticut Seed Leaf $\ldots \ldots \ldots \ldots \ldots \ldots \ldots \ldots \ldots \ldots \ldots \ldots \ldots \ldots,{ }_{10}^{\text {Pkt. }}{ }_{30}^{\text {Oz. }}$

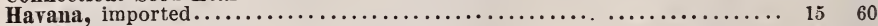

Virginia, James River $\ldots \ldots \ldots \ldots \ldots \ldots \ldots \ldots \ldots \ldots \ldots \ldots \ldots \ldots \ldots \ldots \ldots \ldots \ldots \ldots, 15 \quad 40$

TURNIP. Brissica RAPA.

For early use, sow in fifteen-inch drills as soon as the ground can be worked, and thin to five inches in the rows. For main crop, sow from last week in July to last week in August. Cover the seed lightly. Sow just before rain, if possible, as the success of this crop depends upon a quick, early growth. For field culture, Turnips are usually sown broadcast; but much larger crops are obtained by cultivating in drills, particularly of the Ruta Baga.

WHITE FLESH VARIETIES.

Early Six Weeks, pure white, early, handsome.......... Pkt. Oz. Lb.

Snowball, fine white, round, smooth and handsome............... ${ }_{5} \quad \begin{array}{ll}10 & 70\end{array}$

White Flat Dutch, medium size, white, of quick growth; can be used

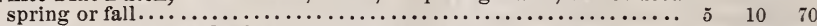

Red, or Purple-Top Strapleaf, a popular market sort; mild, sweet, and a rapid grower; the best kind for spring or fall................. 5 ह $10 \quad 70$

White-Top Strapleaf, pure white, flat turnip; a popular sort......... 5 $10 \quad 70$ Jersey Navet, an oblong, white variety, of sweet, mild flavor, growing underground; fine for table use........................... ร $\quad \begin{array}{ll}70 & 10\end{array}$

YELLOW FLESH VARIETIES.

Yellow Malta, very handsome, early, small-bulbed, fine-grained and good $\quad \begin{array}{llll}5 & 10 & 70\end{array}$ Aberdeen, hardy, productive, tender, solid, valuable for table or stock $\quad 5 \quad 10 \quad 60$ Robertson's Golden Stone, or Orange Jelly, a superior sort; quick growth, fine flavor; excellent for table or stock; a good keeper....

\section{TURNIP, Ruta-Baga. Brassica Campestris Nabo-Brassica.}

Ruta-Baga, or Swedes, should be sown from the middle of June to the 1st of July : sow in drills two feet apart, and thin to ten inches; plant in dry land, thoroughly enriched. Turnips are particularly useful for feeding to stock in winter.

White French, or Sweet German, large white, sweet; retains its fresh-

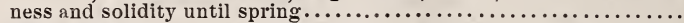

Skirving's Purple-Top, a standard variety ; large size; quick grower; an excellent field sort for table or stock; yell ow flesh; good for shal-

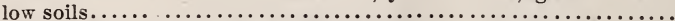

Laing's Improved, one of the handsomest sorts in cultivation; of best

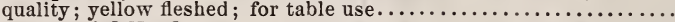

Carter's Imperial Hardy, very productive; claimed to be the best purple

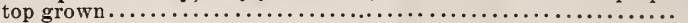

$\begin{array}{ccc}\text { Pkt. } & \text { Oz. } & \text { Lb. } \\ 5 & 10 & 70 \\ & & \\ 5 & 10 & 50 \\ 5 & 10 & 50 \\ 5 & 10 & 70\end{array}$

\section{SWEET AND POT HERBS.}

Cultivate in rich, open soil. Sow in spring, in drills, and thin out to four or more inches apart. Some judgment should be exercised in gathering herbs to preserve in a dry state. They should be cut when not quite in bloom, and on a dry day. Dry them quickly out of the sun.

Inise (Tragium Sativum) $\ldots \ldots \ldots$ Pkt. $\mathrm{Oz}$.

Basil Sweet (Ocymum Basilicum). $\quad 5 \quad 30$

Carraway (Carum Carui) ........ 5 s 10

Catnep (Nepeta Cataria) ......... $10 \quad 60$

Coriander, (Coriandrum Sativum. 510

Dill (Anethum Graveolens) ...... 510

Fennel (Anethum Fœnidulum) .... $\quad$ 5 10

Horehound (Marrubium Vulgare). $10 \quad 30$

Hyssop (Hyssopus Officinalis).... $\quad 5 \quad 20$

Ice Plant (Mesembryanthemum

Crystallinum ................ 5 5 30

Lavender (Lavendula Spica)..... $5 \quad 25$

Evidence or Quality.

Rose Cottage Green-Houses, Lexixeton, Mass.

I bonght of you last July was the best I ever grew; the roots were very smonth and fine in quality. I took the first prize at the Exhibition of the Mass. Hort. Society, in Sept. JAMEs CoxLEY.
Marjorum, Sweet or Knotted (Origanum Majorana) ............ 5 25

Rosemary(RosemarinusOfficinalis) $\quad 5 \quad 50$

Sage (Salvia Officinalis) per lb.\$2. 520

Savory Summer (Satureia Hortensis...................

Saffron (Carthamus Tinctorious), (annual) $\ldots \ldots \ldots \ldots \ldots \ldots \ldots$

Thyme (Thymus Vulgaris) .......

Wormwood (Artemesia Absisthium $\ldots \ldots \ldots \ldots \ldots \ldots$........ 530 


\section{SPOONER'S LAWN GRASS MIXTURE.}

FOR IIGIIT, MEDIUM AND FIEAVY SOILS.

\section{Per Bush., \$3.j0; per Pk., \$1.00; per A2t., 20c. Two Hushels or more, \$3.00, by express. Extra fine, per ibushel, + tob, wy express. No charge for bags.}

From three to four bushels are required to the acre for forming new lawns.

\section{Hints on the Formation and Improvement of Garden Lawns.}

A good close velvety turt is one of the most vinamental objects in a landscape, and oftentimes the most difficult to obtain.

In the first place, careful preparation of the ground proposed to be laid down to turf is necessary. This should be commenced in the winter by araining, it found requisite, and digging to the depth of six or twelve iniches, according to the vature of the soll. "When this has been done, the laud should be levelled and made firm with a roller, aud subsequently raked, to remove stones, \&c. Should the natural soil be too stony, it wil be advisable to procure a supply of good loam, and spread it over the land to the depth of two or three iuches. If the soil is poor, some well rotted stable dung will be very beneticial. In Aprrl, after the ground has been made thoroughly fine and clean, a heavy rolier should ugain be used to make it perfectly level; and as the subsequent appearance of the Lawn depenus in a great measure on this part of the prefaration, we cannot too strongly urge the importance of its being well done. The ground should then be evenly raked, and the seed sown. April and september are the best months for sowing, but it may be sown in Spring as late as the middle of May, and trom the last week in Augnst until the middle of October.

After the sowing has been accomplished, the ground should be again rolled, and as soou as the young plants Lave attained the height of two or three inches, the whole plot should be carefully gone over with a sharp scythe, and from the mopths of April to October it should be mown every ten days. Frequeut mowing and rolling are indispensuble to maintain the turf in good order. Mowing machines are excellent after a comparatively close turf is established, but the first six montls after sowing we reeommend the use of the scythe.

For Lawns requiring improrement, sow tresh seed, at the rite of about one bushel per acre, either in the spring or ailumu, isitis a small tooth rake, and rolling afterwards.

Clover, White Duteh (Irifolium repens).............per 1b., by nail, 56c.; by express, 4 Uc.

\section{VARIOUS GRASSES.}

Red-Top Grass (Agrostis vulgaris). Desirable as a mixture in either pasture or lawn grasses ; wi1l grow almost auy where. Huout 2 bushels to the acre (14 llos. to bushel). Per packet, 5c.; per quart, 10c.; per bushel, $\$ 1.50$.

Kentucky Blue Grass (Poa Pratensis), known as June Grass, thrives best in dry soils, producing herbage early in the season; valuable as a mixture with other grasses for lawns; $14 \mathrm{lbs}$, to bushel, $1 \frac{1}{2}$ to 3 un-hels to the acre. Yer pkt., 5s.; per quart, 10c.; per bushel, $\$ 2.00$.

Rhode Island Bent Grass (Agrostis stolonifera), au excellent variety for lawns, il lbs. to bnshel, 2 to 3 bushels to the acre. Per $\mu \mathrm{kt}$., 10c ; per quart, $15 \mathrm{c}$.; per bushel, $\$ 3.50$.

Timothy, or Herds Grass (Phleum pratense). More extensively grown than any other variety, more productive and nutriciou, than any other kind; $45 \mathrm{lbs}$. to a bushel, to to 1 bushel to the acre. Per pkt., 10e., market price.

These prices uru subject to slight variations in the market, in quotations by the bushel, express to be paid by purchaser.

Temit Ifc. per pound, or 10c. per quart, extra, when urdered by mail,

\section{Quantity of Vegetable seeds, de., Generally Used per Acre.}

Beans, dwarf, in drills, $1 \frac{1}{2}$ to 2 bush. Ouion, 4 to $6 \mathrm{lbs}$.

Beaus, pole, in hills, 10 to 12 quarts. Onion, for Sets, in drills, 301 bs.

Beet, 4 to 6 lbs:

Cabbage, in hills, $8 \mathrm{oz}$.

Carrot, 3 to 5 lbs.

Chinese Sugar Care, 10 to 12 lbs.

Mangel Wurzel, in drills, 4 lbs.

Musk Mrion, in hills, 2 to 3 lbs.

Water Meloir, in Lills, 4 to 5 lbs.

Millet, 1/2 bush.

Mustard, broaldcast, $1 / 2$ bush.

Quantity of Vegetable

Asparagus, $1 \mathrm{oz}$. for 60 feet.

Dwarf Beans, 1 qt. for 100 feet.

Beet, $1 \mathrm{oz}$. for 50 feet.

Carrot, $1 \mathrm{oz}$. for 300 feet.

Endive, $1 \mathrm{oz}$. for 150 feut.

Onion, 1 oz. for 200 feet.

Union Sets, in drills, 10 bush.
Top Union Sets, 1 to $11 / 2$ bush.

Parsnip, 3 to 5 lbs.

Peas, $1 \frac{1}{2}$ to 2 bush.

Potatoes (cut tubers), 10 bush.

Pumpkin, in hills, 5 to 6 lbs.

Radish, in urills, 6 to $81 \mathrm{los}$.

Ruta Baga, 1 to $11 \frac{1}{2}$ lbs.

Sage, in drills, 4 to $6 \mathrm{lbs}$.

Onion Sets, 1 qt. for 20 feet.

Okra, 1 oz. for 40 feet.

Parsley, $1 \mathrm{oz}$. for 150 feet.

Parsulp, $1 \mathrm{oz}$. for 200 lect.

l'e:as, small, 1 qt. for 180 feet.

Peas, Jarge, 1 qt. for 140 feet.
Salsify, in drills, 8 to $10 \mathrm{lbs}$. spinach, in drills, 10 to $12 \mathrm{lbs}$.

Squash, bush varieties, in hills, 3 to $4 \mathrm{lbs}$.

Squash, running varieties, in hills, 2 to $2 \frac{1}{2} \mathrm{lbs}$.

Tomuto, in bed, to transplant, 2 oz.

Turnip, broadcast; 3 to 4 lbs.

T'urnip, in drills, 1 to $1 \frac{1}{2} \mathrm{lbs}$.

\section{Seeils Generally Used for a Given Length of Drill.}

Radish, 1 oz. for 100 feet.

Salsily, $1 \mathrm{oz}$. for 70 feet.

spiuach, $1 \mathrm{oz}$. for 100 feet.

Turuips, $1 \mathrm{oz}$, for 300 feet.

\section{Catalogues mailed tree to applirants.}




\section{SPOONER'S BOSTON MARKET

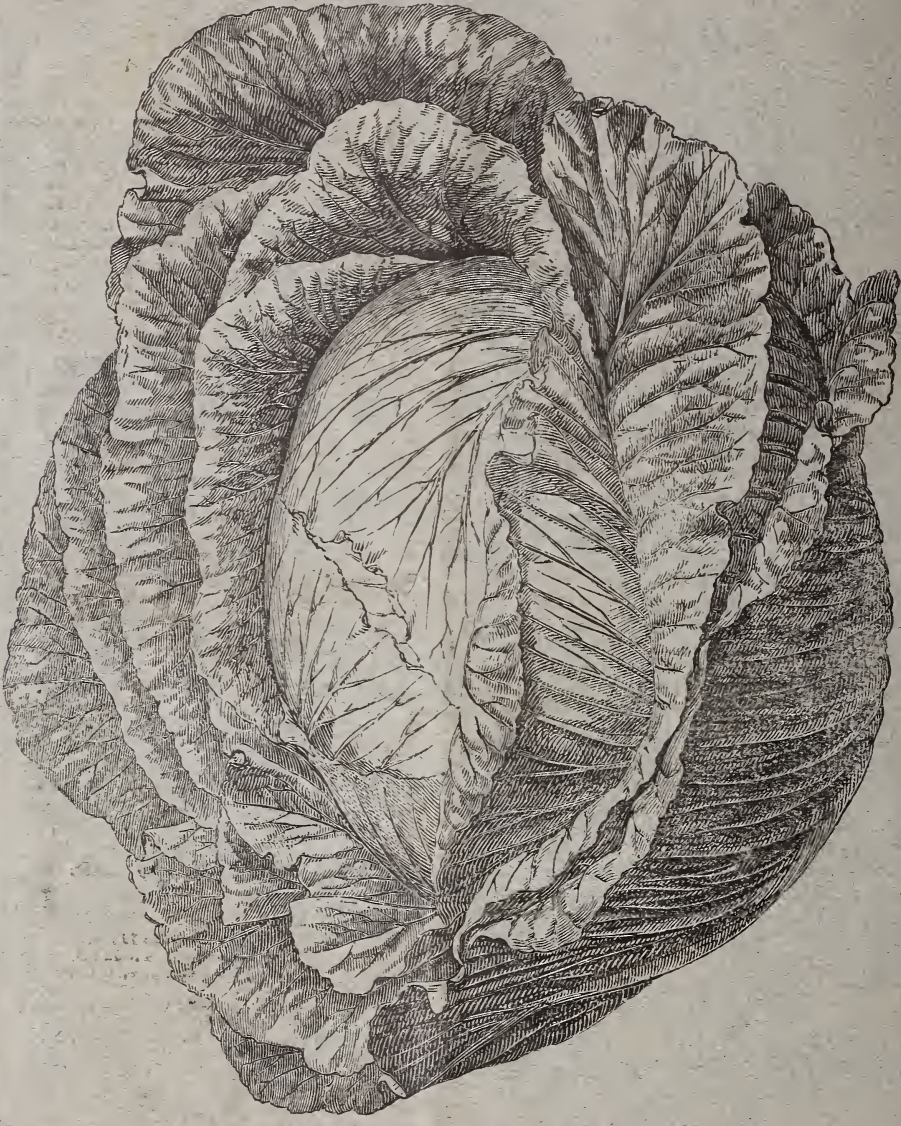

CABBAGE, MARBLEHEAD MAMMOTH DRUMHEAD.

\section{VEGETABLE SEEDS.}

